UNIVERSIDADE DE SÃO PAULO

FACULDADE DE MEDICINA DE RIBEIRÃO PRETO

DEPARTAMENTO DE NEUROCIÊNCIAS E CIÊNCIAS DO COMPORTAMENTO

MARILI ANDRÉ COELHO

Avaliação neurológica de recém- nascidos com microcefalia secundária à infecção congênita pelo vírus Zika 
Marili André Coelho

\section{Avaliação neurológica de recém- nascidos com microcefalia secundária à infecção congênita pelo vírus Zika}

Dissertação apresentada ao Programa de Mestrado Profissional em Neurologia e Neurociências da Faculdade de Medicina de Ribeirão Preto para obtenção do título de Mestre em Ciências.

Área de concentração: Neurologia do Desenvolvimento Orientadora: Profa. Dra. Ana Paula Andrade Hamad

Ribeirão Preto

2019 
Autorizo a reprodução e divulgação total ou parcial deste trabalho, por qualquer meio convencional ou eletrônico, para fins de estudo e pesquisa, desde que citada à fonte.

\section{FICHA CATALOGRÁFICA}

Coelho, Marili André

Avaliação Neurológica de Recém- nascidos com microcefalia secundária à infecção congênita pelo vírus zika. Marili André Coelho/ Orientadora: Ana Paula Andrade Hamad. Ribeirão Preto, 2019.

$122 p$.

Dissertação (Mestrado Profissional) - Programa de Neurologia e Neurociências Clínicas. Área de concentração: Neurologia do Desenvolvimento. Faculdade de Medicina de Ribeirão Preto da Universidade de São Paulo, Ribeirão Preto, 2018.

1.Vírus Zika 2. Microcefalia 3. Exame neurológico Neonatal. 


\section{MARILI ANDRÉ COELHO}

\section{Avaliação neurológica de recém- nascidos com microcefalia secundária à infecção congênita pelo vírus Zika}

Dissertação apresentada ao Programa de Mestrado Profissional em Neurologia e Neurociências da Faculdade de Medicina de Ribeirão Preto para obtenção do título de Mestre em Ciências.

Área de concentração: Neurologia do Desenvolvimento

Data da defesa:

Resultado:

\section{BANCA EXAMINADORA}

Prof ${ }^{a}$. Dra. Ana Paula Andrade Hamad

Universidade de São Paulo - orientadora

Universidade de São Paulo - orientadora
$\operatorname{Prof}^{\mathrm{a}} \mathrm{Dr}^{\mathrm{a}}$

$\operatorname{Prof}^{\mathrm{a}} \mathrm{Dr}^{\mathrm{a}}$

Prof $^{\mathrm{a}} \mathrm{Dr}^{\mathrm{a}}$

Universidade de São Paulo - orientadora 


\section{DEDICATÓRIA}

Dedico este trabalho primeiramente a Deus, que é o motivo maior de todo meu empenho e, de forma muito especial, a todos da minha família, por depositarem tanta confiança e fé na minha escolha profissional desde o início, além de serem meus eternos incentivadores na busca pelo crescimento pessoal e profissional.

Sei que sempre posso contar com o apoio e amor incondicional de vocês para que eu possa seguir nesta caminhada da vida.

Vocês são minha inspiração.

Obrigada! 


\section{EPÍGRAFE}

"É o cuidado que você dedicou a sua rosa que a faz tão especial."

(O Pequeno Príncipe) Antoine de Saint-Exupéry 


\section{AGRADECIMENTOS}

Agradeço primeiramente a Deus, pela a oportunidade de aprimorar meus estudos.

Aos meus amados familiares, que me apoiaram mesmo perante o cansaço da dedicação para conclusão deste trabalho e que sempre se mantiveram ao meu lado, não me deixando desistir jamais.

Aos meus queridos amigos, pela compreensão nos momentos de ausência, apoio nas dificuldades e alegria em cada passo desta conquista.

A Prof $^{a} \operatorname{Dr}^{a}$ Ana Hamad pela sua dedicação, compreensão, paciência, horas despendidas neste trabalho, além de toda experiência profissional e pessoal, conhecimento técnico científico e compreensão da vida que pudemos compartilhar neste processo.

À querida Dra Carla Andrea Tanuri Caldas, por ter tornado esse projeto possível através de sua dedicação incansável a cada uma das crianças envolvidas, da busca constante do conhecimento necessário para tal tarefa e pelo seu comprometimento com a formação de um mundo melhor, mesmo em meio às dificuldades inerentes a nossa profissão. Obrigada por sua amizade e apoio neste percurso.

À Prof ${ }^{a}$ Dr $^{a}$ Carolina Araújo Rodrigues Funayama por ter acolhido a mim e a este trabalho antes mesmo de haver um projeto estabelecido e por me mostrar que era possível percorrer este caminho mesmo em meio à nossa exaustiva formação profissional.

Ao $\operatorname{Prof}^{\circ} \mathrm{Dr}^{\circ}$ Vítor Tumas por ter auxiliado a viabilização deste projeto mesmo nos momentos mais críticos que foram enfrentados.

Ao Prof $^{\circ} \operatorname{Dr}^{\circ}$ Amilton Antunes Barreira (in memoriam), por ter sido, desde o início, entusiasta no estudo proposto neste trabalho e por todo apoio e incentivo para realização do mesmo. 
Aos colegas neuropediatras, pelo companheirismo e pela amizade nesta jornada.

Aos médicos assistentes da Neurologia Infantil, pelo exemplo de profissionalismo e pelo conhecimento compartilhado desde o início da minha formação.

E por fim, a cada paciente e seus familiares, por confiarem suas vidas à nossa equipe $e$ auxiliarem no meu crescimento profissional e pessoal ao longo desses anos. 
COELHO, Marili André. Avaliação neurológica de recém-nascidos com microcefalia secundária à infecção congênita pelo vírus Zika. 2018. 122 f. Dissertação (Mestrado em Ciências) - Departamento de Neurologia e neurociências da Faculdade de Medicina de Ribeirão Preto da Universidade de São Paulo. Universidade de São Paulo, Ribeirão Preto, 2018.

\section{RESUMO}

INTRODUÇÃO: Houve uma epidemia de infecção pelo vírus Zika (ZIKV) no Brasil, entre 2015 e 2016, que refletiu no aumento de casos de microcefalia neonatal secundária à infecção congênita pelo ZIKV. Para compreensão do padrão de acometimento neurológico dessas crianças foi realizado um projeto de pesquisa pelo Hospital das Clínicas da Faculdade de Medicina de Ribeirão Preto da Universidade de São Paulo (HCFMRP-USP), conhecido como ZIG, e realizado seguimento neurológico desses pacientes por meio do Exame Neurológico de Hammersmith Neonatal (HINE-N). OBJETIVOS: Avaliar pacientes com microcefalia secundária à infecção congênita pelo ZIKV por meio do HINE- N, descrever as características clínicas e de neuroimagem dos pacientes estudados e identificar fatores pré-natais, perinatais e demográficos potencialmente relacionados ao grau de comprometimento do exame neurológico. METODOLOGIA: O presente estudo faz parte do Núcleo de Estudos sobre Infecção Materna, Perinatal e Infantil (NEIMPI) do HCFMRP-USP e trata-se de um estudo não experimental, transversal, com intuito de correlacionar variáveis qualitativas e quantitativas. Participaram do estudo crianças com microcefalia secundária à infecção congênita pelo ZKV nascidas no município de Ribeirão Preto e seu Departamento Regional de Saúde (DRS XIII), no período de outubro de 2015 a dezembro de 2016. Os dados foram coletados no período de outubro de 2015 a janeiro de 2017. Realizou-se avaliação do perímetro craniano (PC), aplicação do HINE e coleta de dados em prontuário. Os dados foram processados e analisados com a utilização do Pacote Estatístico Statistical Package for the Social Sciences (SPSS), versão 22.0. RESULTADOS: Foram avaliadas 18 crianças, sendo predomínio do sexo feminino $(55,6 \%)$, nascidas a termo, com exceção de uma que nasceu com 32 semanas, maioria originária de Ribeirão Preto $(66,7 \%)$, via de parto normal $(72,2 \%)$, ocorrido no Centro Obstétrico do HCFMRP - USP (83,3\%), todas as crianças tiveram APGAR maior que 7 . O peso de nascimento foi entre 1228 e 3200 gramas, com PC entre 26 e $31,5 \mathrm{~cm} .72,2 \%$ das crianças fizeram ultrassom transfontanela e $100 \%$ fizeram ressonância magnética de encéfalo, com associação entre os resultados encontrados neles (ambos com $\mathrm{p}<\mathrm{ou}=0,001)$. O score HINE-N foi baixo, porém não foram encontradas associações entre o score e as variáveis clínicas (ambos com p>0,05). Evidenciou-se associação entre a realização de pré-natal e a cidade de residência, local de nascimento, diagnóstico de microcefalia e de infecção pelo ZIKV no pré-natal, tipo de parto $(\mathrm{p}<\mathrm{ou}=0,001)$. A medida do PC apresentou associação direta com a presença de crise convulsiva $(\mathrm{p}<0,05)$ e houve associação entre crise convulsiva, ventriculomegalia e calcificação $(\mathrm{p}<\mathrm{ou}=0,001)$. CONCLUSÃO: O padrão de acometimento neurológico das crianças com microcefalia secundária à infecção congênita pelo ZIKV é muito severo, com presença de sinais precoces de paralisia cerebral desde o exame neonatal. Este estudo sugere seguimento prospectivo desses pacientes para melhor avaliação prognóstica e associação do score HINE com condições clínicas pré e perinatais.

Palavras-chave: Vírus Zika. Microcefalia. Exame neurológico neonatal. 
COELHO, Marili André. Neurological assessment of neonates with microcephaly due to congenital Zika vírus infection. 2018. 122p. Dissertation (Professional Master's degree) Ribeirão Preto Medical School, University of São Paulo, Ribeirão Preto, 2018.

\begin{abstract}
INTRODUCTION: There was an epidemic of Zika virus infection (ZIKV) in Brazil between 2015 and 2016, which reflected the increase in cases of neonatal microcephaly secondary to congenital ZIKV infection. A study was carried out for the Hospital das Clínicas of the University of São Paulo at Ribeirão Preto Medical School (HCFMRP-USP), and the followup of these patients was performed using the Neonatal Hammersmith Neurological Exam (HINE-N) aiming to understand the neurological involvement pattern of these children. OBJECTIVES: To evaluate patients with microcephaly secondary to ZIKV congenital infection using HINE-N, to describe the clinical and neuroimaging characteristics of the patients studied, and to identify prenatal, perinatal and demographic factors potentially related to the degree of impairment of neurological examination. METHODOLOGY: This study is part of the Center for Studies on Maternal, Perinatal and Child Infection (NEIMPI) of the HCFMRP-USP. It is a non-experimental, cross-sectional study aimed at correlating qualitative and quantitative variables. Children with microcephaly secondary to congenital ZKV infection born in the city of Ribeirão Preto and its Regional Health Department (DRS XIII), from October 2015 to December 2016, participated in the study. Data were collected in the period of October 2015 to January 2017. An evaluation of the cranial perimeter (PC), the application of HINE and data collection in medical records were performed. Data were processed and analyzed using the Statistical Package for Social Statistical Package (SPSS), version 22.0. RESULTS: A total of 18 children were evaluated, being 55,6\% female, all to term with the exception of one who was born at 32 weeks, most of them from Ribeirão Preto (66.7\%), normal delivery (72.2\%), occurred in the Obstetric Center of the HCFMRP - USP $(83.3 \%)$, all children had APGAR greater than 7. The birth weight was between 1228 and 3200 grams, with PC between 26 and $31.5 \mathrm{~cm}$. $72.2 \%$ of the children had transfontanel ultrasonography and $100 \%$ had brain magnetic resonance imaging, with an association between the results found in them (both with $\mathrm{p}<$ or $=0.001$ ). The HINE-N score was low, but no associations were found between the score and the clinical variables (both with $\mathrm{p}>0.05$ ). It was evidenced an association between prenatal and city of residence, place of birth, diagnosis of microcephaly and ZIKV infection in the prenatal period, type of delivery ( $\mathrm{p}<$ or $=0.001$ ). The PC measurement presented a direct association with the presence of seizures $(\mathrm{p}<0.05)$ and there was an association between seizure, ventriculomegaly and calcification ( $\mathrm{p}<\mathrm{or}=$ 0.001). CONCLUSION: The pattern of neurological involvement of children with microcephaly secondary to congenital ZIKV infection is very severe, with early signs of cerebral palsy since the neonatal examination. This study suggests a prospective follow-up of these patients for better prognostic evaluation and association of the HINE score with pre and perinatal clinical conditions.
\end{abstract}

Keywords: Zika virus. Microcephaly. Neonatal neurologic assessment. 


\section{LISTA DE SIGLAS E ABREVIATURAS}

\begin{tabular}{|c|c|}
\hline AIG & Adequado para Idade Gestacional \\
\hline BPN & Baixo Peso ao Nascer \\
\hline CDC & Centers for Disease Control and Prevention \\
\hline CEP & Comitê de Ética em Pesquisa \\
\hline CER & Centro Especializado De Reabilitação \\
\hline CMV & Citomegalovírus \\
\hline DRS & Departamento Regional de Saúde \\
\hline EBPN & Extremo Baixo Peso ao Nascer \\
\hline EHI & Encefalopatia Hipóxico-Isquêmica \\
\hline GIG & Grande para Idade Gestacional \\
\hline HCFMRP- USP & $\begin{array}{l}\text { Hospital das Clínicas da Faculdade de Medicina de Ribeirão Preto da } \\
\text { Universidade de São Paulo }\end{array}$ \\
\hline HINE & Exame Neurológico de Hammersmith \\
\hline HINE- N & Exame Neurológico de Hammersmith Neonatal \\
\hline IG & Idade Gestacional \\
\hline LCR & Líquido cefalorraquidiano \\
\hline MBPN & Baixo Peso ao Nascer \\
\hline MDC & Malformação do desenvolvimento cortical \\
\hline MDCSNC & Malformação cortical do sistema nervoso central \\
\hline MFSNC & Malformação do Sistema Nervoso Central \\
\hline MS & Ministério da Saúde \\
\hline NASF & Núcleo de Apoio à Saúde da Família \\
\hline NEIMPI & Núcleo de Estudos sobre Infecção Materna, Perinatal e Infantil \\
\hline OMS & Organização Mundial da Saúde \\
\hline $\mathbf{P C}$ & Perímetro craniano \\
\hline PCR & Reação em cadeia da polimerase \\
\hline PEATE & Potencial Evocado Auditivo de Tronco Encefálico \\
\hline PIG & Pequeno para Idade Gestacional \\
\hline PN & Peso de nascimento \\
\hline $\mathbf{R M}$ & Ressonância magnética \\
\hline
\end{tabular}


RN

RNPT

RNT

RT- PCR

SGB

SN

SNC

SUS

TCLE

US

USTF

ZIKV
Recém- nascido

Recém- nascido pré- termo

Recém- nascido a termo

Reação em cadeia da polimerase via transcriptase reversa

Síndrome de Guillain Barré

Sistema nervoso

Sistema nervoso central

Sistema Único de Saúde

Termo de Consentimento Livre e Esclarecido

Ultrassom

Ultrassom transfontanela

Vírus Zika 


\section{LISTA DE QUADROS}

Quadro 1. Apresentação das variáveis, unidade utilizada e categorização, Ribeirão Preto, 2018. 39

Quadro 2. Variáveis sua classificações e apresentação dos dados, Ribeirão Preto, 2018........40 


\section{LISTA DE TABELAS}

Tabela 1. Distribuição das medidas descritivas do perímetro cefálico de acordo com o sexo, Ribeirão Preto, 2018.

Tabela 2. Distribuição dos diagnósticos de microcefalia e infecção pelo vírus Zika no prénatal, Ribeirão Preto, 2018.

Tabela 3. Distribuição das alterações evidenciadas no exame de ultrassom transfontanela, Ribeirão Preto, 2018. 46

Tabela 4. Distribuição das alterações evidenciadas no exame de ressonância magnética, Ribeirão Preto, 2018.

Tabela 5. Distribuição do tipo de malformação do desenvolvimento cortical evidenciada por meio de ressonância magnética, Ribeirão Preto, 2018.

Tabela 6. Distribuição do Exame Neurológico de Hammersmith Neonatal em relação à postura e tônus, padrões e tônus, reflexos e movimentos de acordo com o sexo, Ribeirão Preto, 2018.

Tabela 7. Distribuição do Exame Neurológico de Hammersmith Neonatal em relação aos padrões e sinais anormais e comportamento de acordo com o sexo, Ribeirão Preto, 2018.....48

Tabela 8. Medidas descritivas dos domínios do Exame Neurológico de Hammersmith Neonatal, Ribeirão Preto, 2018.

Tabela 9. Associação entre o perímetro cefálico e as variáveis presença de crise, presença de ventriculomegalia, calcificação e malformações na ressonância magnética e no ultrassom transfontanela. Ribeirão Preto, 2018.

Tabela 10. Associação do pré-natal as variáveis cidade de residência, local de nascimento, diagnóstico de microcefalia no pré-natal, diagnóstico de infecção pelo vírus Zika no pré-natal, tipo de parto. Ribeirão Preto, 2018.

Tabela 11. Associação do pré-natal e as variáveis idade gestacional, peso de nascimento, tempo de internação e score total do Exame Neurológico de Hammersmith Neonatal. Ribeirão Preto, 2018.

Tabela 12. Associação da variável crise neonatal e suas categorias e as variáveis idade gestacional, peso de nascimento, tempo de internação e score total do Exame Neurológico de Hammersmith Neonatal. Ribeirão Preto, 2018.

Tabela 13. Associação entre crise neonatal e as variáveis local de nascimento, tipo de parto, ventriculomegalia, calcificação e malformação no ultrassom transfontanela. Ribeirão Preto, 
Tabela 14. Associação crise neonatal e as variáveis ventriculomegalia, calcificação e malformação na ressonância magnética. Ribeirão Preto, 2018.

Tabela 15. Associação entre diagnóstico pré- natal de infecção pelo vírus Zika e as variáveis idade gestacional, perímetro cefálico, tempo de internação e score total do Exame Neurológico de Hammersmith Neonatal. Ribeirão Preto, 2018.

Tabela 16. Associação entre diagnóstico de microcefalia no pré- natal e as variáveis idade gestacional, perímetro cefálico, tempo de internação e score total do Exame Neurológico de Hammersmith Neonatal. Ribeirão Preto, 2018. 53

Tabela 17. Associação entre diagnóstico pré- natal de infecção pelo vírus Zika e as variáveis: cidade de residência, local de nascimento e tipo de parto. Ribeirão Preto, 2018.

Tabela 18. Associação entre diagnóstico pré- natal de microcefalia e as variáveis cidade de residência, local de nascimento e tipo de parto. Ribeirão Preto, 2018.

Tabela 19. Correlação score total no Exame Neurológico de Hammersmith Neonatal e as variáveis idade gestacional, perímetro cefálico, peso de nascimento, APGAR e tempo de internação. Ribeirão Preto, 2018.

Tabela 20. Associação entre score total no Exame Neurológico de Hammersmith Neonatal e as variáveis: sexo, local de nascimento, tipo de parto, crise neonatal, prematuridade extrema, ventriculomegalia, calcificação e malformação na ressonância magnética e ultrassom transfontanela e tipo de malformação na ressonâncica magnética. Ribeirão Preto, 2018........55

Tabela 21. Associação entre crise convulsiva e os domínios do Exame Neurológico de Hammersmith Neonatal- postura e tônus, padrões de tônus, reflexos, movimentos, padrões e sinais anormais, comportamento e score total. Ribeirão Preto, 2018.

Tabela 22. Associação entre tipo de malformação do sistema nervoso central as variáveis: perímetro craniano, peso de nascimento, Exame Neurológico de Hammersmith Neonatal postura e tônus, padrões de tônus, reflexos, movimentos, padrões e sinais anormais, comportamento e score total. Ribeirão Preto, 2018.

Tabela 23. Associação entre as variáveis ventriculomegalia na ressonância magnética e no ultrassom transfontanela, calcificação na ressonância magnética e no ultrassom transfontanela e malformação na ressonância magnética e no ultrassom transfontanela, Ribeirão Preto, 2018.

Tabela 24. Associação entre score total no Exame Neurológico de Hammersmith Neonatal e o tipo de malformação (lisencefalia isolada, lisencefalia associada, polimicrogiria e outros). Ribeirão Preto, 2018. 


\section{LISTA DE FIGURAS}

Figura 1. Casos confirmados de Síndrome do Zika Vírus de 2015 a 03 de março de 2018, por estado brasileiro.

Figura 2. Fluxograma das etapas da coleta de dados. .36 


\section{LISTA DE IMAGENS}

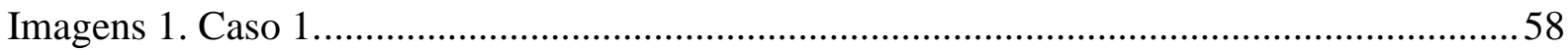

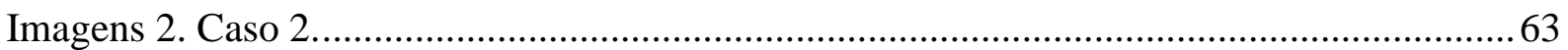

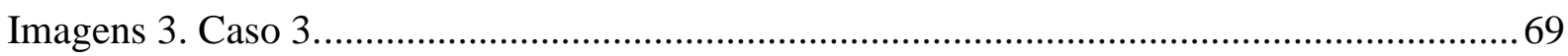




\section{LISTA DE GRÁFICOS}

Gráfico 1. Distribuição do perímetro craniano de acordo com o sexo, Ribeirão Preto,

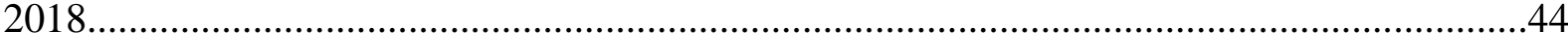

Gráfico 2. Dispersão do valor total do perímetro craniano, Ribeirão Preto, 2018 ................... 44

Gráfico 3. Dispersão do score total do Exame Neurol+ogico de Hammersmith Neonatal,

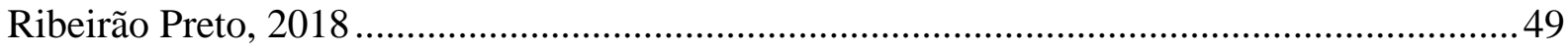




\section{SUMÁRIO}

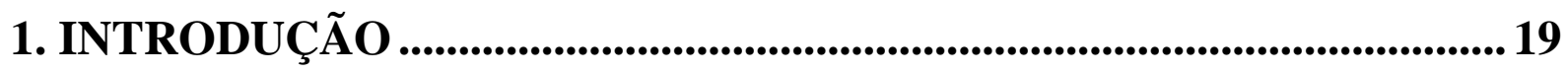

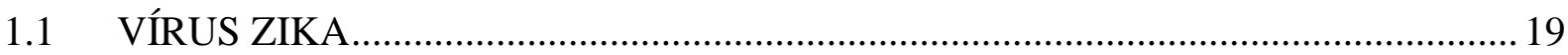

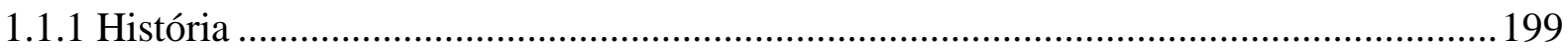

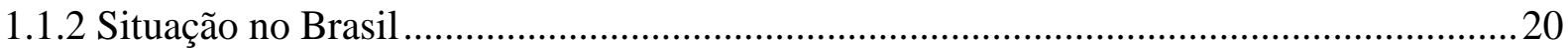

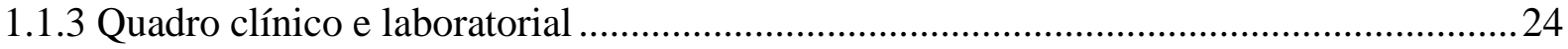

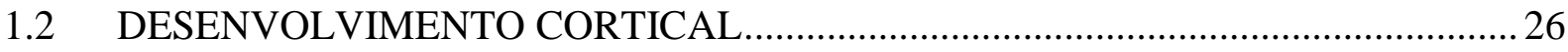

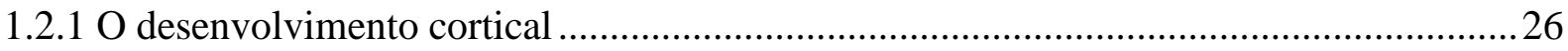

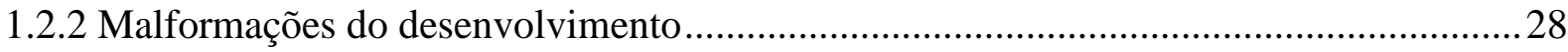

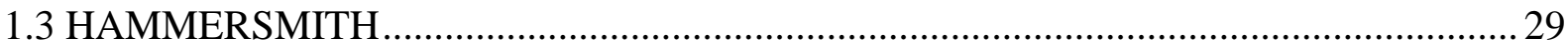

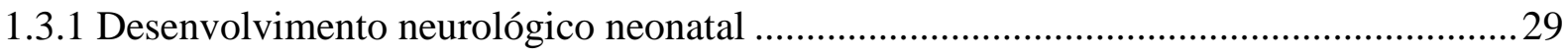

1.3.2 Escalas e instrumentos de avaliação neurológica neonatal ............................................ 30

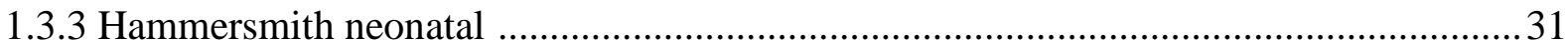

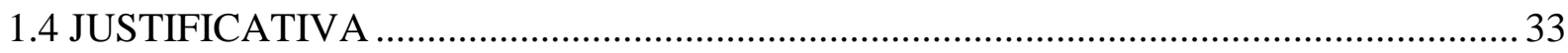

2. OBJETIVOS ......................................................................................................................... 34

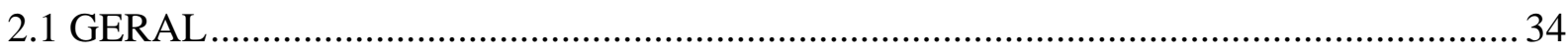

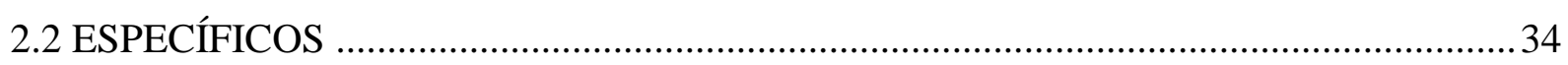

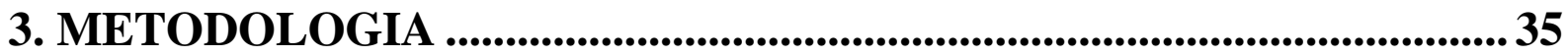

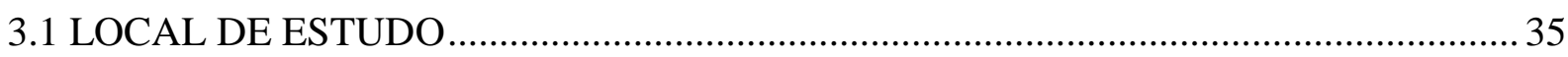

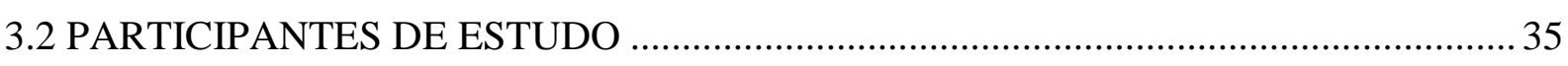

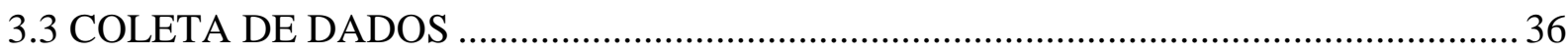

3.3.1 Avaliação do perímetro craniano............................................................................. 37

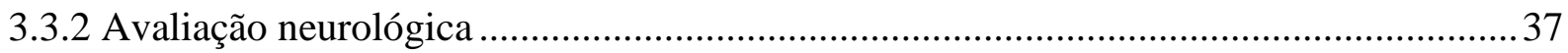

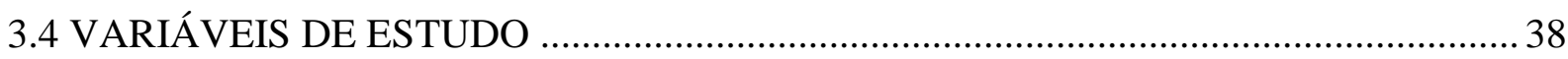

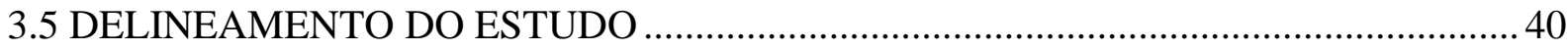

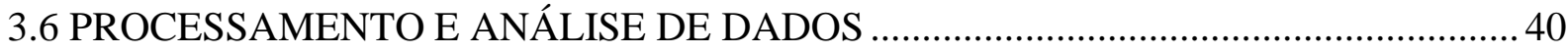

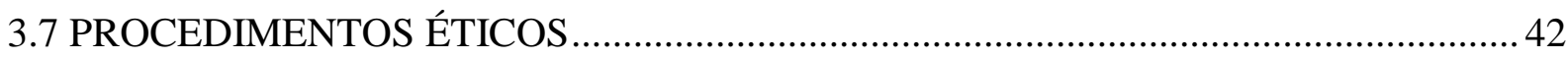

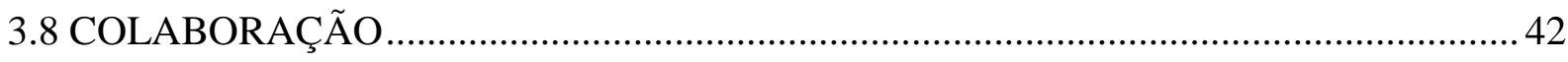




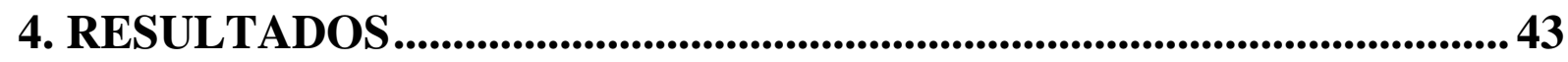

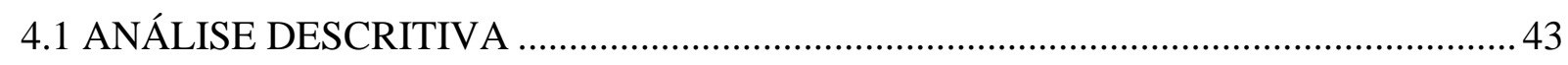

4.2 ANÁLISE DE SIGNIFICÂNCIA ESTATÍSTICA …………............................................ 50

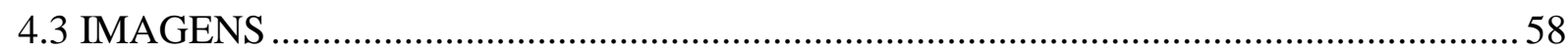

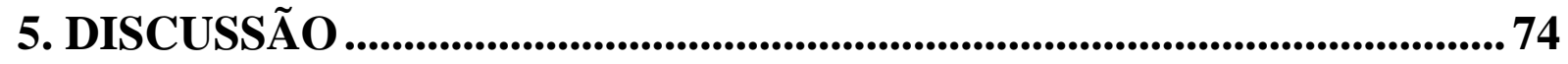

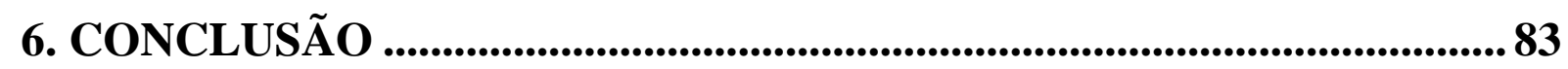

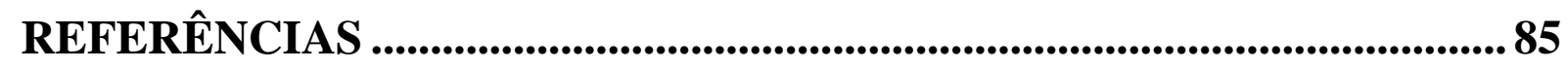

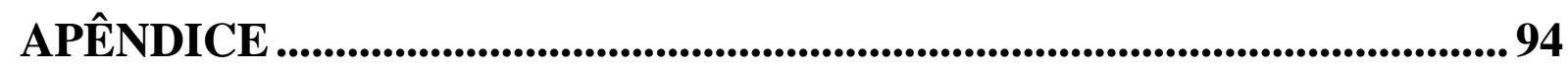

APÊNDICE I - Termo de Consentimento Livre e Esclarecido ................................................... 94

ANEXOS ........................................................................................................... 104

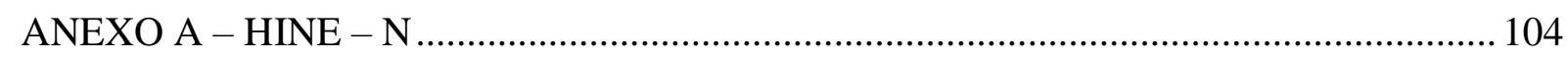

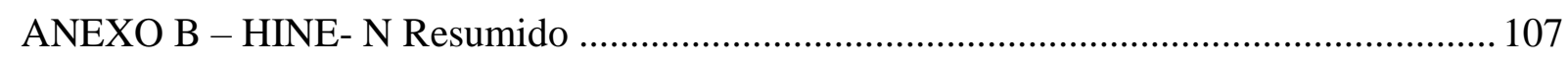

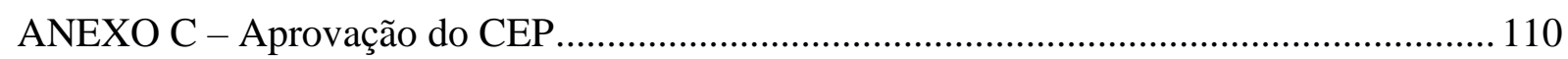




\section{INTRODUÇÃO}

\subsection{VÍRUS ZIKA}

\subsubsection{História}

$\mathrm{O}$ vírus Zika (em inglês zika vírus, abreviatura ZIKV) é um arbovírus pertencente ao gênero Flavivirus da família Flaviviridae, isolado pela primeira vez em Uganda, África, no ano de 1947, em macacos Rhesus, na floresta Zika. Posteriormente, foi encontrado também em mosquitos silvestres na mesma região e nos anos 1960 foram documentados os primeiros casos febris em humanos (ALVINO; MELLO; OLVEIRA, 2016; KUNO et al., 1998; DICK et al., 1952).

Em 1960, o ZIKV apareceu em mosquitos Aedes aegypti na Ásia, inicialmente na Malásia, o que evidenciou que este arbovírus também existia fora da África. Segundo Alvino, Mello e Oliveira (2016), este foi o marco para constatação da adaptação do vírus e de seu potencial epidêmico, uma vez que ele havia se associado a um vetor importante de doenças humanas, como a Febre Amarela Urbana, os quatro sorotipos da Dengue e a Chikungunya.

Poucos casos e sem gravidade foram documentados em humanos até que, em 2007, houve uma epidemia de febre exantemática relacionada ao ZIKV na Polinésia Francesa e em vários países da Oceania. Foram então documentadas cerca de 30000 infecções, as primeiras associações da infecção com a Síndrome de Guillain- Barré (SGB) e os primeiros casos de transmissão perinatal (MUSSO et al., 2014; BESNARD et al., 2014; BALM et al., 2012; LANCIOTTI et al., 2008).

Segundo o European Center for Disease Prevention and Control (2015), 17 casos de malformações do sistema nervoso central (MFSNC) em fetos e recém-nascidos (RN) foram encontrados entre março de 2014 e maio de 2015 na Polinésia, sem associação com sintomatologia materna. No entanto, foram encontrados anticorpos para esse vírus em sorologia de quatro gestantes testadas, sugerindo infecção assintomática.

A principal forma de transmissão do ZIKV é o vetor mosquito do gênero Aedes, A. albopictus no ciclo selvagem e A. aegypti no ciclo urbano, mas também foi descrita transmissão por via sexual e por contato de secreções (saliva, urina), bem como a via vertical (congênita) (NUNES et al., 2016). 


\subsubsection{Situação no Brasil}

Em maio de 2015, foram identificadas as primeiras ocorrências no Brasil por método de biologia molecular. (VARGAS, et al. 2016). A cepa isolada era asiática e, portanto, tais casos eram autóctones da Polinésia, com hipótese de terem chegado ao Brasil por ocasião da Copa do Mundo da Federação Internacional de Futebol de 2014 (ZANLUCA et al., 2015).

A estimativa inicial era de 440000 a 1,3 milhões de casos autóctones de infecções ZIKV relatados até dezembro de 2015 (EUROPEAN CENTER FOR DISEASE PREVENTION AND CONTROL, 2015).

O primeiro caso descrito, em outubro de 2015, foi uma gestante europeia de 25 anos que vivia no Brasil e teve uma doença febril com rash cutâneo no final do primeiro trimestre de gestação. O ultrassom (US) com 29 semanas evidenciou microcefalia com calcificações cerebrais e placentárias e a mãe solicitou término da gestação, que foi feito na Europa, com 32 semanas. Na autópsia fetal foi observada microcefalia com completa agiria, hidrocefalia e calcificações multifocais em região cortical e sucortical. O ZIKV foi encontrado no tecido fetal do cérebro (MLAKAR, 2016).

No segundo semestre de 2015, principalmente na região Nordeste do Brasil, houve um aumento no número de casos de microcefalia e a consequente busca por sua (CAMARGO Jr, 2016) etiologia, cujos estudos indicavam infecção materna pelo ZIKV. No Brasil, em 2015, a frequência de microcefalia foi maior em 20 vezes o número de casos ocorridos entre 2000 e 2014 (SILVA, 2018).

O Instituto Evandro Chagas apontou essa relação causal ao isolar o ZIKV do cérebro e o identificar no líquido cefalorraquidiano (LCR), cérebro e fragmentos de várias vísceras de um RN que foi a óbito logo após o nascimento (KINDHAUSER et al., 2016).

Após esse dado, foram detectados anticorpos IgM para ZIKV no LCR em 12 RN nascidos com microcefalia, nos quais as testagens sorológicas para toxoplasmose, rubéola, citomegalovírus, herpes simples 1 e 2, dengue e chikungunya eram negativas (FARIAS et al., 2016).

O aumento dos casos teve importância nacional, sendo decretada a microcefalia como emergência em Saúde Pública pelo Ministério da Saúde (MS). A média de casos de microcefalia entre 2010 e 2014 era de 156 casos ao ano, com crescimento para 1247 em 2015, sendo 646 no estado de Pernambuco (VARGAS et al., 2016). 
Diante disso, no Brasil, foi modificado o valor de perímetro craniano (PC) a ser notificado junto ao MS como microcefalia: o que era anteriormente considerado $33 \mathrm{~cm}$ passou a ser $32 \mathrm{~cm}$ para os RN com 37 semanas ou mais de IG, devido à alta sensibilidade do corte anterior (SOUZA et al., 2016).

Com o aumento dos casos cada vez mais evidente, o Centers for Disease Control and Prevention (CDC), junto com a Organização Mundial de Saúde (OMS), definiram diretrizes para o tratamento de gestantes durante o surto de ZIKV e estabeleceram um consenso, após novas revisões, para a definição de microcefalia. Para recém-nascidos a termo (RNT) masculino foi estabelecido PC $<32 \mathrm{~cm}$ e para RNT feminino, $\mathrm{PC}<31,5 \mathrm{~cm}$ (FARIAS et al., 2016).

Para os recém-nascidos pré-termo (RNPT) com menos de 36 semanas, foram utilizadas as curvas de dados antropométricos de referência Intergrowth 21 (PAPAGEORGHIOU et al., 2014, 2016).

Essa referência foi selecionada por representar várias populações, permitir avaliar fetos a partir da $14^{\mathrm{a}}$ semana gestacional, RNT e RNPT ao nascimento e em seu crescimento pós-natal, além de guardar boa associação com referências de crescimento da OMS.

Nesse contexto, de alteração do padrão de ocorrência de microcefalia nos $\mathrm{RN}$ do país, esta foi considerada um agravo emergencial em saúde pública, uma vez que interfere na qualidade de vida das crianças e suas famílias, além de poder aumentar a mortalidade infantil. O MS, em conjunto com outras instituições envolvidas, elaborou um Protocolo de Orientações para cuidado desses casos (BRASIL, 2016). Esse protocolo orientava como uma das ações prioritárias:

- O combate ao mosquito Aedes aegypti: eliminação de possíveis criadouros, limpeza de terrenos, descarte apropriado do lixo e materiais e utilização adequada da água;

- Ações de atenção à saúde sexual e reprodutiva: orientação do planejamento familiar e distribuição de métodos contraceptivos;

- Acompanhamento de gestantes: diagnóstico precoce da gestação com orientação sobre a prevenção da infecção pelo ZIKV principalmente no primeiro trimestre - por meio da utilização de telas em janelas e portas, uso de roupas compridas e uso de repelente;

- Seguimento de puérperas e RN com suspeita de microcefalia. 
As gestações eram seguidas como pré-natal de baixo risco, com consultas mensais até a $28^{\mathrm{a}}$ semana, quinzenal entre a $28^{\mathrm{a}}$ e $36^{\mathrm{a}}$ e semanal a partir da $36^{\mathrm{a}}$ semana, com recomendação de US obstétrico no primeiro trimestre, exames como eletroforese de hemoglobina, sorologia para toxoplasmose e os testes rápidos de sífilis e HIV, realização de vacinação conforme o calendário vacinal do MS, suplementação com ácido fólico e sulfato ferroso, abordagem do uso de medicamentos e substâncias tóxicas e registro da ocorrência de infecções, rash cutâneo, exantema ou febre.

Caso esses sintomas durassem cinco dias e fossem excluídas outras doenças infecciosas e não infecciosas, era coletado material para exame - sangue e urina - e notificado o caso, conforme Protocolo de Vigilância e Resposta à ocorrência de microcefalia secundária ao ZIKV.

Se houvesse diagnóstico laboratorial conclusivo, definia-se como caso confirmado para gestante. Caso houvesse, US obstétrico com microcefalia definia-se como caso suspeito. A indicação da via de parto continuava sendo obstétrica em ambos os casos.

No nascimento deveria ser realizada a medição do PC e, em caso de microcefalia, coletados os materiais para exame específico - sangue de cordão umbilical, placenta, sangue da mãe e LCR, além de triagem infecciosa, sorologias, exames laboratoriais inespecíficos. Eram realizados também exames de imagem e Potencial Evocado Auditivo de Tronco Encefálico (PEATE). Não havia contraindicação para amamentação em seio materno.

Além de serem encaminhadas para seguimento de puericultura, essas crianças deveriam realizar acompanhamento para estimulação precoce em serviço de reabilitaçãoCentro Especializado de Reabilitação (CER), Centro de Reabilitação em Medicina Física, Centro de Reabilitação Física, fisioterapeuta, fonoaudiólogo ou terapeuta ocupacional do Núcleo de Apoio à Saúde da Família (NASF) ou vinculados às equipes da Atenção Básica ou em um Ambulatório de Seguimento de RN de risco.

A princípio, os casos de ZIKV foram confirmados nos estados do Nordeste, em maio de 2015, com rápida dispersão para outras regiões do país, com o registro de 141 casos suspeitos de microcefalia em novembro de 2015 no Estado de Pernambuco (OLIVEIRA; VASCONCELOS, 2016).

A figura 1 demonstra os casos confirmados de Síndrome do Zika Vírus ocorridos entre os anos de 2015 a 2018, por estado brasileiro. 
Figura 1. Casos confirmados de Síndrome do Zika Vírus de 2015 a 03 de março de 2018, por estado brasileiro.

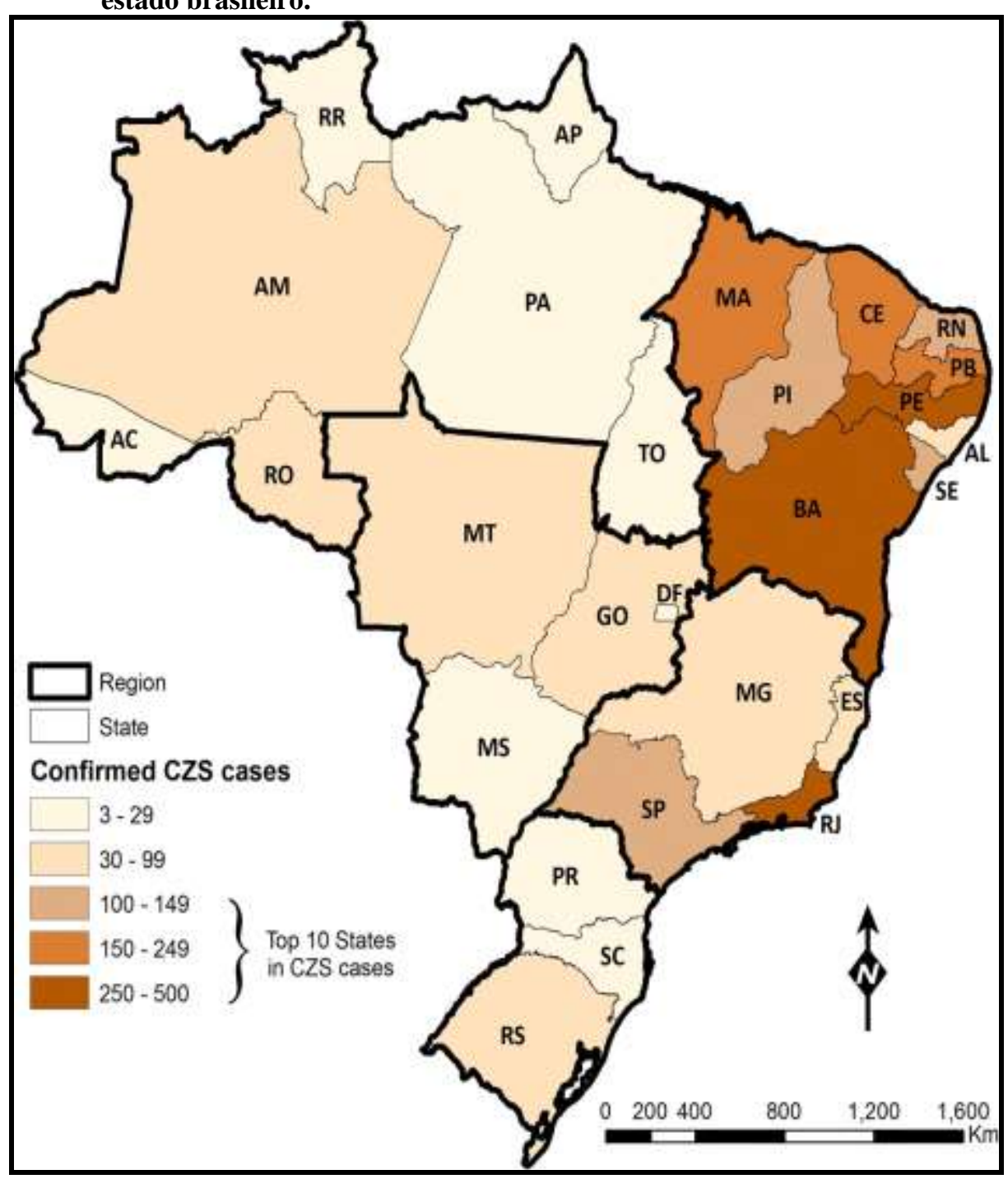

Fonte: CASTRO et al., 2018.

Em Ribeirão Preto, devido às condições climáticas que favoreciam a proliferação do vetor Aedes aegypti e as epidemias do vírus da dengue que a cidade estava vivenciando, houve uma preocupação geral dos profissionais de saúde e da população acerca da infecção congênita pelo ZIKV.

Segundo o Ribeirão Preto (2016), em seu boletim epidemiológico referente aos meses de janeiro e fevereiro de 2016, houve 2326 casos suspeitos de infecção pelo ZIKV, sendo 516 gestantes. Essas fizeram parte de uma coorte de mulheres com infecção diagnosticada e foram acompanhadas no projeto ZIG do Hospital das Clínicas da Faculdade de Medicina de Ribeirão Preto da Universidade de São Paulo (HCFMRP- USP), segundo as normas preconizadas pelo MS (MUSSI et al., 2016). 
O Brasil registrou um total de 3720 casos confirmados de infecção congênita pelo ZIKV na Organização Panamericana de Saúde até janeiro de 2018, destes, 1682 casos suspeitos eram do estado da Bahia, segundo informações do último Boletim Epidemiológico da Secretaria Estadual de Saúde da Bahia (PAN AMERICAN HEALTH ORGANIZATIO, 2017).

\subsubsection{Quadro clínico e laboratorial}

A infecção pelo ZIKV é um quadro usualmente autolimitado, que pode ser assintomático ou cursar com sintomas como rash maculopapular, frequentemente pruriginoso, edema de extremidades, febre baixa $\left(<38,5^{\circ} \mathrm{C}\right)$, mialgia, cefaleia, dor retro ocular, vertigem, hiperemia conjuntival e artralgia (VARGAS et al., 2016).

Usualmente o quadro agudo desaparece em aproximadamente cinco dias (CARDOSO et al., 2015; DUFFY et al., 2009). Porém, cerca de 80\% das pessoas acometidas pelo ZIKV são assintomáticas (DUFFY et al., 2009).

Apesar de haver pouco conhecimento acerca do padrão imunológico de resposta ao ZIKV, sabe- se que as manifestações clínicas e a gravidade do caso dependem da combinação da resposta imunológica desenvolvida pelo hospedeiro e de fatores de patogenicidade virais (MUSSI, 2016; WHITERHORN; SIMMONS, 2011).

Há relatos de manifestações pós-infecciosas, como a SGB e quadros de meningoencefalite (CARTEAUX et al., 2016; OEHLER et al., 2014).

Para confirmação diagnóstica da infecção pelo ZIKV, pode-se realizar a reação em cadeia da polimerase via transcriptase reversa (RT-PCR) em espécimes clínicos coletados, idealmente, até o $5^{\circ}$ dia - se amostra sérica - ou até o $11^{\circ}$ dia - se amostra urinária - do início dos sintomas, uma vez que o período de viremia parece curto (um a sete dias) (SULLIVAN, 2015; MUSSI, 2016).

Devido à ocorrência de reações cruzadas com diferentes flavovírus, não há testes sorológicos diagnósticos eficazes, o que dificulta a triagem de gestantes assintomáticas (DUARTE, 2016).

A transmissão viral se dá pela picada do mosquito do gênero Aedes, por via sexual, transplacentária, sanguínea e por meio da amamentação natural (CUNHA et al., 2016; HILLS et al., 2016; OSTER et al., 2016; MUSSO et al., 2015a; MUSSO et al., 2015b; BESNARD et al., 2014). 
Sabe-se que o ZIKV atravessa a barreira placentária, conseguindo atingir o líquido amniótico e os tecidos fetais, com potenciais danos ao embrião/feto (MLAKAR et al., 2016; BESNARD et al., 2013).

O acometimento fetal é tão mais severo quanto mais precoce for à infecção materna (primeiro trimestre), uma vez que o ZIKV apresenta tropismo pelas células nervosas em desenvolvimento, particularmente no período de mitose neuronal e glial, migração neuronal e organização do SNC, comprovado por necropsia fetal com isolamento viral por reação em cadeia da polimerase (PCR) em tecidos cerebrais (ALVINO; MELLO; OLVEIRA, 2016; MUSSI, 2016).

A microcefalia pode estar associada a um distúrbio da fase de proliferação neuronal, que ocorre por volta do $3^{\circ}$ e $4^{\circ}$ meses de gestação. Outras malformações do desenvolvimento cortical do sistema nervoso central (MDCSNC) fetal também podem estar presentes, como distúrbios da migração neuronal (3 a 5 meses de gestação) e calcificações difusas (morte neuronal) (VOLPE, 2011).

Com isso, os fetos acometidos por esta infecção podem nascer com microcefalia, MFSNC, alterações do desenvolvimento neuropsicomotor (DNPM), bem como deficiência intelectual e outros acometimentos neurológicos, sendo a epilepsia um dos mais prevalentes (SOUZA et al., 2016).

Outras alterações relacionadas à microcefalia são déficit intelectual, epilepsia, paralisia cerebral, hipertonia, irritabilidade, atraso no desenvolvimento de linguagem e/ou motor, estrabismo e outras desordens oftalmológicas, cardíacas, renais e do trato urinário (BRUNONI et al., 2016; FAUCI et al., 2016).

As crianças avaliadas apresentam em comum hiperreflexia e hipertonia, além de déficit na função manual. Os achados fonoaudiólogos evidenciam imaturidade e incoordenação das funções de sucção, deglutição e respiração inadequadas (BOTELHO et al., 2016).

As disfunções gástricas, como refluxo gastroesofágico, disfagia e aspiração broncopulmonar podem não ser claras desde o início, o que torna imperativa a monitorização das mamadas (RODRIGUES; RODRIGUES, 2017). O desenvolvimento da função visual é prejudicado devido à presença de lesão macular e perimacular, atrofia corriorretiniana e anormalidades no nervo óptico (URZÊDA et al., 2009).

Além dos casos de MFSNC, há outras malformações que podem estar associadas, sendo a artrogripose a mais recorrente, a qual leva a uma limitação da movimentação com 
alterações estruturais e/ou funcionais da cápsula articular e ligamentos (ALVINO; MELLO; OLVEIRA, 2016).

Em Recife (Pernambuco) foram avaliadas 106 crianças com diagnóstico provável ou confirmado de infecção congênita pelo ZIKV, das quais 40 (37,7\%) apresentavam crises epilépticas: $43,3 \%$ do tipo espasmo, 22,7\% crise generalizada tônica, 20,5\% parcial e 4,5\% inespecíficas (ALVES et al., 2016).

A associação de infecção pelo ZIKV e epilepsia é elevada, uma vez que a prevalência de epilepsia estimada na grande São Paulo é de 1,19\% (BORGES et al., 2004; MARINO JR. et al., 1986).

O US obstétrico é o método disponível para acompanhar o crescimento fetal e a presença de microcefalia, definida como PC menor que dois ou três desvios padrão abaixo da média para a IG (BARSUKO et al., 2009; TAN et al., 2008; WHO, 2007).

No entanto, devido à raridade da microcefalia congênita, não há dados da evolução do crescimento do PC no período gestacional. Nas séries relatadas, o achado mais prevalente é a microcefalia, seguido de ventriculomegalia, contorno craniano irregular, cisterna magna alargada, agenesia total e parcial do vermis cerebelar e um caso de macrocrania (SOUZA et al., 2016).

De acordo com Rodrigues e Rodrigues (2017), as principais alterações de neuroimagem encontradas são calcificações, ventriculomegalia, alteração geral como polimicrogiria, redução do volume cerebral, atrofia cortical e malformação, hipoplasia de cerebelo, vermis cerebelar e tronco, atraso da mielinização e hipoplasia do corpo caloso. $\mathrm{Na}$ avaliação ultrassonográfica fetal pode-se não encontrar essas alterações da síndrome ZIKV, o que torna necessária a realização de US transfontanelar ao nascimento, antes da alta hospitalar.

\subsection{DESENVOLVIMENTO CORTICAL}

\subsubsection{O desenvolvimento cortical}

O processo de formação do córtex cerebral tem etapas sucessivas e sobrepostas de proliferação, migração e organização celular, que são reguladas por múltiplos mecanismos moleculares, cascatas de sinalização e expressão de genes (MUÑOZ; LÓPES-MESAS; VALIENTE, 2010). 
A princípio, na embriogênese, o tubo neural formará o neuroeixo de forma precoce, seguido da condensação focal, expansão e diverticulação, que são desencadeadas pela expressão compartimentalizada de genes e eventos celulares. Rostralmente, as vesículas telencefálicas se formam e dão origem aos hemisférios cerebrais. O epitélio ventricular e os precursores estriatais dão origem aos neurônios que constituirão o neocórtex (RODRIGUES; RODRIGUES, 2016).

Os neurônios têm origem na matriz germinativa, que são as células germinativas da camada subependimária da parede dos ventrículos, a chamada matriz germinativa. Os neuroblastos, células dessa matriz com diferenciação neuronal não madura, iniciam o processo de migração. A partir da $8^{\mathrm{a}}$ semana, os neurônios da região periventricular migram para superfície do córtex cerebral, orientados pelas fibras radiais. Os núcleos e o córtex cerebelar também são formados nesse mesmo período. Primeiro migram as células que irão formar a camada 1 do córtex e depois as que formarão as camadas VI, V, IV, III e II, respectivamente (BIELAS et al., 2004).

Posteriormente, foram reconhecidas outras formas de migração neuronal, como o modelo tangencial, em que os neurônios podem migrar por grandes distâncias ao longo das zonas intermediárias, na dependência da expressão de moléculas de adesão específicas (BYSTRON; BLAKEMORE; RAKIC, 2008).

Após estarem organizados nessas diversas camadas, os neurônios se separam das fibras radiais e iniciam a formação dos dendritos e sinapses (RODRIGUES; RODRIGUES, 2016).

Antes do término da migração, inicia-se a maturação dos neurônios: formação e crescimento dos dendritos, desenvolvimento da excitabilidade e polaridade da membrana neuronal, sinaptogênese, síntese de neurotransmissores e mielinização dos axônios. As células gliais são formadas a partir das fibras radiais separadas dos neurônios após a migração. Já as conexões corticais são formadas muito precocemente e continuam a se desenvolver e levam ao desenvolvimento das substâncias cinzenta e branca (CAFFREY et al., 2014).

A organização dos neurônios no córtex cerebral ocorre em locais distantes daqueles que ocupavam a princípio. O neocórtex, cuja organização é extremamente complexa, parece ser mais suscetível a malformações uma vez que as distâncias a serem percorridas para o neocórtex são relativamente maiores (BIELAS et al., 2004; BRITANOVA et al., 2006).

A maior parte desse processo ocorre ao redor da $16^{a}$ semana de gestação, terminando por volta do $5^{\circ}$ mês de vida pós-natal (CRINO; MIYATA; VINTERS, 2002). Há aumento da superfície cortical, sem aumento equivalente de volume, com a sulcação e as circunvoluções 
cerebrais, que também estão diretamente relacionadas à migração neuronal, processo que se prolonga até o primeiro ano de vida (BIELAS et al., 2004).

\subsubsection{Malformações do desenvolvimento}

As três principais etapas de formação do córtex cerebral são proliferação celular, migração celular e organização celular, sendo que quaisquer alterações e interrupções em uma dessas fases ocasionam as malformações do desenvolvimento cortical (MDC) (TASSI et al., 2002).

Apesar de se tratar de um grupo bastante heterogêneo de transtornos anatômicos, as MDC podem ser classificadas em quatro grupos principais de acordo com critérios histológicos e de imagens estabelecidos por Barkovich (2010) e Barkovich e colaboradores (2001):

- Grupo I: malformações secundárias à proliferação neuronal anormal e glial ou apoptose. Este grupo é subdividido em três categorias: proliferação reduzida ou apoptose acelerada (microcefalias); aumento da proliferação ou diminuição da apoptose (megalencefalias) e proliferação anormal (displasia cortical focal ou difusa);

- Grupo II: malformações devidas à migração neuronal anormal que são subdivididas em quatro subcategorias: malformações no início do processo de migração; incluindo, principalmente, as heterotopias; complexo lisencefalia "cobblestone"; síndromes de distrofias musculares congênitas;

- Grupo III: MDC pós-migratórias, sendo subdivididas em três grupos: polimicrogiria e esquizencefalia; displasias corticais focais e microcefalia pósmigratória;

- Grupo IV: Malformações secundárias a erros inatos do metabolismo e outras malformações não classificáveis.

Do grupo II, destaca-se a lisencefalia, que é uma falha no desenvolvimento de sulcos e giros, ocorrendo entre a $12^{\mathrm{a}}$ e $24^{\mathrm{a}}$ semana gestacional devido a um defeito na migração neuronal de todos os neurônios, cuja consequência é uma superfície cerebral lisa, com ausência completa de giros na superfície cerebral, córtex desorganizado e volume da substância branca reduzida (BARKOVICH, 2010; BARKOVICH et al.,2001). 
Os autores ainda relatam que a paquigiria tem a mesma patogenia, mas é mais focal, restrita a alguns giros ou áreas corticais, com sulcos rasos. Geralmente essas alterações estão associadas a outras MFSNC, como a microcefalia.

Do grupo III, temos a polimicrogiria que é decorrente de alterações no processo final da migração neuronal e no início da organização cortical, usualmente no período pósmigratório, entre a 20 e $24^{\mathrm{a}}$ semana de vida intrauterina. Na maioria das vezes se situa no território de irrigação das artérias cerebrais médias. Sua superfície cortical é irregular à custa de múltiplos giros de tamanhos pequenos e circunvoluções anormais, o córtex é mais espesso e não há limites claros entre a substância branca e cinzenta (BARKOVICH et al.,2001; BARKOVICH, 2010;).

Já a esquizencefalia, que é um fenômeno pós- migratório, usualmente é associada à polimicrogiria ou a outras malformações, sendo caracterizada pela presença de uma fenda transcortical delineada por substância cinzenta desde a superfície ventricular até a superfície pial, que comunica as meninges com os ventrículos laterais. Dentre as MDC, é a mais grave. Pode ser dividida em tipo 1 e tipo 2 ou de lábios fechados e de lábios abertos, conforme alterações anatômicas presentes. O princípio dos eventos que levam a esta alteração ocorre no terceiro mês de gestação (RODRIGUES; RODRIGUES, 2017).

\subsection{HAMMERSMITH}

\subsubsection{Desenvolvimento neurológico neonatal}

O DNPM depende do processo de maturação do SNC em especial no primeiro ano de vida. Esse processo está relacionado com o grau de mielinização, arborização e formação de sinapses das células nervosas do SNC. Essas vão, progressivamente, inibir as atividades reflexas primitivas e assumir o controle voluntário dessas atividades em pacientes hígidos. Com a maturação do SNC há inibição da atividade reflexa primitiva presente no RN e o início das reações de retificação, proteção, equilíbrio, desenvolvimento intelectual e integração das funções sensoriais (OLHWEILER, 2005).

A investigação dos reflexos primitivos é importante para avaliar a integridade do sistema nervoso (SN); alguns desaparecem nos seus primeiros meses de vida para retornar como atividade motora voluntária no segundo semestre de vida, enquanto outros irão desaparecer em condições normais e sua presença indicará patologia do SN (OHLWEILER, 2005). 
A evolução das funções corticais superiores vai da recepção cortical primária sensitivo-sensorial às mais altas funções integrativas (gnosias) e dos reflexos motores à automatização da sequência de movimentos aprendidos (praxias) (FUNAYAMA, 2004).

Os primeiros meses do exame neurológico tem um pobre valor indicativo de ausência ou presença de lesão neurológica efetiva e, por esse motivo, devem ser associadas a um conjunto de elementos como história perinatal, convulsões neonatais, MFSNC, microcefalia, alterações nos exames de imagem, entre outros. No entanto, sabe-se que a avaliação da qualidade dos movimentos gerais dos RN, que envolve cabeça, tronco e membros, é um forte preditor do desenvolvimento neurológico dessas crianças (SERGIO; 2010; HADDERSALGRA 1996; PRECHTL et al.,1991; ALFORD et al., 1990).

Esses movimentos se iniciam durante a vida fetal, persistem até 3 ou 4 meses de idade pós termo, assim quando o exame neurológico habitual passa a ter maior valor preditivo (HOPKINS; PRECHTL 1984; VRIES et al., 1982).

\subsubsection{Escalas e instrumentos de avaliação neurológica neonatal}

Diante do acometimento neonatal pelo ZIKV no Brasil, foi feita revisão literária das formas de avaliação neurológica neonatal. Nas últimas cinco décadas houve diversas propostas para essa avaliação, sendo que todas avaliavam os mesmos aspectos - tônus de tronco e membros, reflexos e movimentação ativa - como preditivos de lesões neurológicas, porém analisados de maneiras diferentes (NASCIMENTO et al., 2011).

Apesar de a escola Francesa despontar como inovadora na avaliação neurológica neonatal a partir de 1952, desenvolvida por André Thomas, seguida de Saint- Anne Dargassies e Amiel- Tisson, sabe-se que o precursor do exame neurológico neonatal foi o Prof Antonio Branco Lefrève em 1950 (WUSTHOFF, 2013; DIAMENT; WELLER; BERNSTEIN, 1982; DUBOWITZ; DUBOWITZ; GOLBERG, 1970).

Lefrève (1916- 1981) se formou em 1941 pela Faculdade de Medicina da Universidade de São Paulo e desde a graduação manifestava seu interesse pela neurologia. Após realizar um curso de neurologia infantil com Professor Ary Borges Fortes, essa se tornou a linha mestra de toda sua especialização (DIAMENT; WELLER; BERNSTEIN, 1982; LEFRÈVE, 1950).

De agosto a outubro de 1950, em um curto período de tempo, defendeu suas duas teses- a de doutorado "Contribuição para o Estudo da Patologia da Afasia em Crianças" e a de livre- docência "Contribuição para a Padronização do Exame Neurológico do Recém- nascido 
Normal". Nesta, Lefrève disserta sobre as bases da semiologia clínica neurológica do RN, precedendo em 2 anos o livro de André Thomas sobre o exame neurológico do RN e do lactente (DIAMENT; WELLER; BERNSTEIN, 1982; LEFRÈVE, 1950).

A escola francesa focava sua avaliação no tônus e reflexos primitivos do RN enquanto Prechtl (1991) propôs a observação do "general movements", que avalia a mobilidade e estado comportamental da criança. No início dos anos 1970, Brazelton sugere a avaliação da interação do RN com seu cuidador com base em aspectos comportamentais, resposta auditiva, visual, tátil e dolorosa, irritabilidade e consolabilidade. Todas essas escalas trouxeram muitos avanços, mas necessitavam de profissionais experientes para realiza-las de forma adequada. (DUBOWITZ; DUBOWITZ; MERCURI, 1999; FUNAYAMA, 1996).

Em 1970 Dubowitz, Dubowitz e Golberg propuseram uma avaliação neurológica neonatal mais objetiva, que foi atualizada e revisada em 1998, hoje conhecida como Avaliação Neurológica de Hammersmith (HINE).

O HINE consiste em uma avaliação rápida, com instruções simples e sem necessidade de treinamento para ser aplicada. No entanto, um desafio da aplicação dessa avaliação é obter a melhor performance do $\mathrm{RN}$ - quando este está calmo e acordado, idealmente entre as mamadas (WUSTHOFF, 2013; (NASCIMENTO et al., 2011; MERCURI; DUNOWITZ, 1999).

\subsubsection{Hammersmith neonatal}

Este instrumento foi desenvolvido na Inglaterra, em 1981, por Dubowitz e colaboradores, com objetivo de identificar RNT e RNPT com risco para anormalidades neurológicas.

No Brasil, o mesmo está sendo submetida a um processo de tradução e validação por meio de um projeto de pesquisa da aluna Mayara Thais Correr, coordenado pela Profa. Dra. Luzia Iara Pfeifer do Departamento de Neurociências e Ciências do Comportamento - Divisão de Terapia Ocupacional.

O protocolo desta avaliação neonatal possui 34 tópicos subdivididos em seis categorias: tônus (dez itens), tipo de tônus (cinco itens), reflexos (seis itens), movimentos (três itens), sinais anormais (três itens) e comportamento (sete itens). As pontuações são calculadas pela soma de todos os itens, sendo a faixa de normalidade total de 30,5 a 34. Cada item pode pontuar 0,0, 0,5 ou 1,0 para anormal, intermediário ou normal, respectivamente (NASCIMENTO et al., 2011). 
A presença de um score global limítrofe não significa necessariamente que a criança avaliada apresente anormalidades neurológicas, mas identifica que esta deve manter seguimento neurológico regular (DUBOWITZ et al., 1999).

Segundo Dubowitz (1999), o exame pode ser aplicado mesmo no RN instável, com duração de 15 minutos. O desempenho em cada um dos itens é registrado em uma folha em sequência, sem a necessidade de seguir a sequência proposta na ficha de avaliação, que pode ser aplicada conforme o estado do bebê.

Segundo o Gupta et al. (2004) que estudou uma coorte de 66 RN com muito baixo peso com score menor de 30,5. Todas as crianças realizaram ressonância magnética (RM) de encéfalo. Quando estudada a relação dos achados do HINE, a sensibilidade encontrada foi de 88\% para identificar crianças com alterações na RM encéfalo.

Nascimento e colaboradores, em 2011, realizaram um estudo prospectivo transversal de 30 RN termo de baixo risco para lesões neurológicas no Hospital Estadual Mário Covas, em Santo André. Foi aplicada a avaliação de Dubowitz e as pontuações obtidas foram analisadas pela distribuição das frequências e valor numérico, com boa correlação com as propostas pelo método em questão. No entanto, neste estudo houve $15 \%$ a mais de score total abaixo do esperado, mostrando a necessidade de validação deste instrumento na população brasileira.

Em 2009, Golin, Souza e Sarni, compararam o resultado do exame aplicado em RNT com RNPT com idade corrigida de termo, concluindo que estes apresentavam pontuação menor que aqueles.

Devido ao grande volume de RN que necessita de avaliação ou do número reduzido de médicos disponíveis para realizá-la, Mercuri et al. (2005) propôs uma versão curta e simplificada do HINE- $\mathrm{N}$ para ser incluída na rotina de exame do RNT. Esta proforma é estruturada de forma que a primeira coluna seja sempre anormal. Crianças com dois ou mais itens listados nessas colunas ou com um ou mais dos sinais anormais listados ao final do exame devem ser reavaliados.

Caso mantenham alterações, o exame completo deve ser aplicado. A versão simplificada é composta por 13 itens, sendo eles: postura e tônus- postura, tração de braço e perna, controle da cabeça extensor e flexor, resposta à tração e suspensão ventral, reflexosreflexo de Moro, movimentos- movimentos espontâneos qualitativos, padrões e sinais anormais- tremor, orientação e comportamento- orientação auditiva, orientação visual e alerta (OLHWEILER et al., 2005). 
Em 2008, Romeo e colaboradores, sugeriram que o mesmo protocolo reduzido pode ser aplicado em RN pré- termo.

\subsection{JUSTIFICATIVA}

Frente a esse cenário, a avaliação neurológica dos RN acometidos pela infecção congênita por ZIKV, em especial os microcefálicos, tornou-se essencial para maior esclarecimento dessa patologia, bem como para controle clínico e o prognóstico neurológico. 


\section{OBJETIVOS}

\subsection{GERAL}

Avaliar pacientes com microcefalia secundária à infecção congênita pelo ZIKV por meio do HINE- N.

\subsubsection{Específicos}

- Descrever as características clínicas e de imagem dos pacientes estudados;

- Identificar fatores pré-natais, perinatais e demográficos potencialmente relacionados ao grau de comprometimento do exame neurológico. 


\section{METODOLOGIA}

\subsection{LOCAL DE ESTUDO}

O presente estudo faz parte do Núcleo de Estudos sobre Infecção Materna, Perinatal e Infantil (NEIMPI) do HCFMRP- USP.

Houve uma epidemia de ZIKV no ano de 2016, cujos dados foram publicados pelo Boletim Epidemiológico Mensal, editado pela Prefeitura Municipal de Ribeirão Preto e publicado em 01/03/2016, revelaram a existência de 2326 casos suspeitos de infecção pelo ZIKV, incluindo 516 gestantes, referente ao período janeiro e fevereiro de 2016.

Diante disso, as equipes de neonatologia, infecções congênita e obstetrícia uniram esforços para um projeto intitulado "HISTÓRIA NATURAL DA INFECÇÃO PELO VÍRUS ZIKA EM GESTANTES E CONSEQUÊNCIAS PARA A GESTAÇÃO, O FETO E A CRIANÇA (Projeto Zika na Gestação - ZIG)" (MUSSI et al., 2016).

À neurologia infantil coube a evolução neurológica dos RN expostos ao ZIKV durante o período gestacional. Essas crianças foram atendidas regularmente segundo o protocolo de atendimento em unidades ambulatoriais com equipes interdisciplinares, compostas por neuropediatria, pediatria, terapia ocupacional e fisioterapia.

\subsection{PARTICIPANTES DE ESTUDO}

A definição dos participantes do estudo foi baseada no número de gestantes expostas ao ZIKV que foram acompanhadas pelo serviço. Assim, participaram deste estudo crianças afetadas pelo ZIKV com microcefalia nascidos no município de Ribeirão Preto e seu Departamento Regional de Saúde (DRS) 13, no período de outubro de 2015 a dezembro de 2016.

Constituiu-se como critérios de inclusão:

- Mães terem sido acometidas por infecção pelo ZIKV durante a gestação (diagnóstico laboratorial ou presuntivo);

- $\mathrm{RN}$ apresentarem microcefalia ao nascimento.

Os critérios de exclusão estabelecidos foram:

- Não ter realizado o HINE- N;

- Não ter realizado RM. 


\subsection{COLETA DE DADOS}

A coleta de dados ocorreu no período outubro de 2015 a janeiro de 2017, mediante avaliações do PC e aplicação do HINE-N nas crianças que a pesquisadora certificou que se enquadraram nos critérios de inclusão estabelecidos.

Nos casos em que isso ocorreu, as genitoras ou responsáveis legais foram esclarecidas sobre os objetivos da pesquisa, riscos, benefícios e garantia de sigilo, e foi realizado o convite de participação, bem como apresentação e discussão do Termo de Consentimento Livre e Esclarecido (TCLE) (APÊNDICE I), para aquiescência quanto à participação, expressa pela assinatura em duas vias, sendo uma entregue a genitora ou responsável legal e outra mantida sob a guarda da equipe de pesquisa. Depois de oficializada a participação a equipe procedeu as avaliações. A pesquisadora participou na qualidade de integrante da equipe. As etapas da coleta de dados estão demonstradas na figura 2 .

Figura 2. Fluxograma das etapas da coleta de dados.

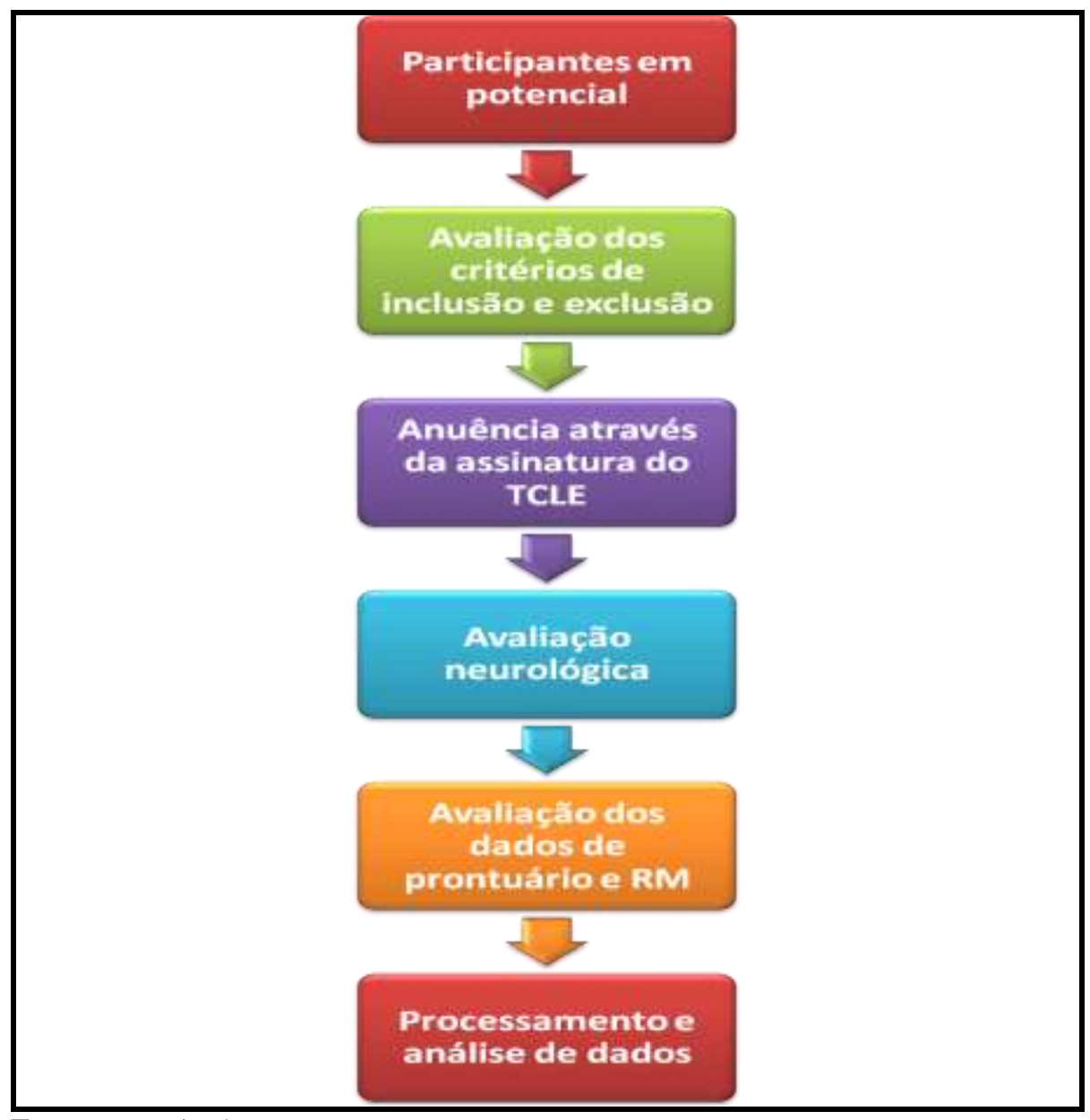

Fonte: Pesquisadora. 


\subsubsection{Avaliação do PC}

Para as crianças a termo, estabeleceu-se como parâmetro do PC menor ou igual a 32 $\mathrm{cm}$ para meninos e $31,5 \mathrm{~cm}$ para meninas.

Entretanto, para os RNPT com menos de 36 semanas, foram utilizadas as curvas de dados antropométricos de referência Intergrowth 21 (PAPAGEORGHIOU et al., 2014, 2016)

\subsubsection{Avaliação neurológica}

A ferramenta utilizada para a avaliação neurológica foi a avaliação sistematizada por meio HINE por se tratar de um exame completo e quantitativo, podendo ser utilizado para análises estatísticas.

O exame consiste em dois protocolos, um aplicado ao período neonatal e outro para o seguimento ambulatorial, de 3 a 24 meses. No presente estudo é apresentado apenas o trabalho realizado na fase neonatal com protocolo específico para essa faixa etária.

Este é composto por 34 tópicos subdivididos em seis categorias, sendo:

- Tônus (dez itens);

- Tipo de tônus (cinco itens);

- Reflexos (seis itens);

- Movimentos (três itens);

- Sinais anormais (três itens);

- Comportamento (sete itens).

As pontuações são calculadas pela soma de todos os itens, que podem pontuar $0,0,0,5$ ou 1,0 se anormal, intermediário ou normal, respectivamente, sendo a faixa de normalidade de 30,5 a 34 (ANEXO I) (NASCIMENTO et al., 2011). A versão simplificada é composta por 13 itens, sendo eles:

- Postura;

- Tração de braço;

- Tração de perna;

- Controle da cabeça extensor;

- Controle da cabeça flexor;

- Resposta à tração;

- Suspensão ventral; 
- Reflexo de Moro;

- Movimentos espontâneos qualitativos;

- Tremor;

- Orientação auditiva;

- Orientação visual;

- Alerta (ANEXO II).

As crianças foram avaliadas no período neonatal, tanto em unidade hospitalar quanto em unidades ambulatoriais dentro do primeiro mês de vida. A avaliação da imagem foi realizada por meio de ultrassom transfontanela (USTF) dentro dos primeiros 30 dias de vida e de RM de encéfalo. Esta foi realizada em aparelho de alto campo 3,0T, com o protocolo de aquisição de imagens de sequências ponderadas em T1, T2, Flair, T2 gradiente eco e/ou sequências de susceptibilidades magnéticas e tensor de difusão (MUSSI et al., 2016).

Os resultados foram categorizados para análise estatística da seguinte forma:

- Presença ou ausência de calcificação;

- Presença ou ausência de ventriculomegalia;

- Presença ou ausência de malformação do desenvolvimento cortical;

- Descrição de qual tipo de malformação, sendo: lisencefalia isolada, lisencefalia associada a outras malformações, polimicrogiria e outros.

\subsection{VARIÁVEIS DE ESTUDO}

As variáveis elencadas para realização do estudo foram: sexo, IG, prematuridade extrema, cidade de origem, local de nascimento, via de parto, peso ao nascer, $\mathrm{PC}$, tempo de internação, realização de pré-natal completo, diagnóstico de microcefalia no pré-natal, diagnóstico de infecção pelo ZIKV no pré-natal, presença de crise neonatal, dados da USTF e da RM, tipos de MFSNC, HINE- N- postura e tônus, padrões de tônus, reflexo, padrões e sinais anormais, comportamento e score total. O quadro 1 mostra as variáveis, unidade a ser utilizada e categorização. 
Quadro 1. Apresentação das variáveis, unidade a ser utilizada e categorização, Ribeirão Preto, 2018.

\begin{tabular}{|c|c|c|}
\hline Variável & Unidade & Categorização \\
\hline \multirow{2}{*}{ Sexo } & & Feminino \\
\hline & & Masculino \\
\hline Idade gestacional & Semanas & - \\
\hline \multirow{2}{*}{ Prematuridade extrema } & \multirow{2}{*}{-} & Sim \\
\hline & & Não \\
\hline \multirow{2}{*}{ Cidade de origem } & \multirow{2}{*}{-} & Ribeirão Preto \\
\hline & & Fora de Ribeirão Preto \\
\hline \multirow{2}{*}{ Local de nascimento } & \multirow{2}{*}{-} & Centro Obstétrico - HCRP \\
\hline & & Outras maternidades \\
\hline \multirow{2}{*}{ Via de parto } & \multirow{2}{*}{-} & Normal \\
\hline & & Cesariana \\
\hline Peso ao nascer & Gramas & - \\
\hline Perímetro cefálico & $\mathrm{Cm}$ & - \\
\hline Tempo de internação & Dias & - \\
\hline \multirow{2}{*}{ Realização de pré-natal } & \multirow{2}{*}{-} & Sim \\
\hline & & Não \\
\hline \multirow{2}{*}{ Diagnóstico de microcefalia no pré-natal } & \multirow[b]{2}{*}{ - } & Sim \\
\hline & & Não \\
\hline \multirow{2}{*}{ Diagnóstico de ZIKA no pré-natal } & \multirow[b]{2}{*}{ - } & Sim \\
\hline & & Não \\
\hline \multirow{2}{*}{ Crise neonatal } & \multirow{2}{*}{ - } & Sim \\
\hline & & Não \\
\hline \multirow{3}{*}{ Ultrassonografia } & \multirow{3}{*}{-} & Calcificação \\
\hline & & Malformação \\
\hline & & Ventriculomegalia \\
\hline \multirow{3}{*}{ Ressonância magnética } & \multirow{3}{*}{-} & Calcificação \\
\hline & & Malformação \\
\hline & & Ventriculomegalia \\
\hline \multirow{4}{*}{$\begin{array}{l}\text { Tipo de malformação do sistema nervoso } \\
\text { central }\end{array}$} & & Lisencefalia isolada \\
\hline & & Lisencefalia associada \\
\hline & & Polimicrogiria \\
\hline & & Outros \\
\hline \multirow{6}{*}{ Exame Neurológico de Hammersmith Neonatal } & \multirow{6}{*}{-} & Postura e tônus \\
\hline & & Padrões de tônus \\
\hline & & Reflexo \\
\hline & & Padrões e sinais anormais \\
\hline & & Comportamento \\
\hline & & Score total \\
\hline
\end{tabular}

Fonte: Pesquisadora 


\subsection{DELINEAMENTO DO ESTUDO}

Trata-se de um estudo não experimental transversal, com intuito de correlacionar variáveis qualitativas e quantitativas.

As variáveis mencionadas foram relacionadas à realização de pré-natal, medida do PC, crise neonatal, score de HINE total e quanto aos subdomínios, bem como achados de imagem.

\subsection{PROCESSAMENTO E ANÁLISE DE DADOS}

Elaborou-se inicialmente um banco de dados com auxílio do programa Excel 2017 da Microsoft, possibilitando a organização dos dados por meio de dicionário (codebook), validado por dupla digitação. Posteriormente, os dados foram exportados para o Pacote Estatístico Statistical Pacckage for the Social Sciences (SPSS), versão 22.0. Analisaram-se os dados com utilização dos fundamentos da estatística descritiva, correlação e teste de hipóteses.

Em relação à estatística descritiva, para as variáveis qualitativas os dados foram apresentados com a utilização de tabelas de frequência absoluta e relativa e, para as variáveis quantitativas, tabelas de frequência absoluta e relativa, medidas de tendência central, sendo média, mediana e moda e medidas de dispersão, sendo desvio padrão, mínimo e máximo, conforme mostra o quadro 2 .

Quadro 2. Variáveis sua classificação e apresentação dos dados, Ribeirão Preto, 2018.

Continua

\begin{tabular}{|c|c|c|c|}
\hline \multicolumn{2}{|c|}{ Variável } & Classificação & Descrição dos dados \\
\hline \multirow{2}{*}{ Sexo } & Feminino & \multirow{2}{*}{ Qualitativa } & \multirow{2}{*}{ Tabela de frequência } \\
\hline & Masculino & & \\
\hline Idade gestacional & - & Quantitativa & $\begin{array}{l}\text { Medidas descritivas e tabela de } \\
\text { frequência }\end{array}$ \\
\hline \multirow{2}{*}{$\begin{array}{l}\text { Prematuridade } \\
\text { extrema }\end{array}$} & Sim & \multirow{2}{*}{ Qualitativa } & \multirow{8}{*}{ Tabela de frequência } \\
\hline & Não & & \\
\hline \multirow{2}{*}{ Cidade de origem } & Ribeirão Preto & \multirow{2}{*}{ Qualitativa } & \\
\hline & Fora de Ribeirão & & \\
\hline \multirow{2}{*}{ Local de nascimento } & $\mathrm{CO}-\mathrm{HCRP}$ & \multirow{2}{*}{ Qualitativa } & \\
\hline & Outras maternidades & & \\
\hline \multirow{2}{*}{ Via de parto } & Normal & \multirow{2}{*}{ Qualitativa } & \\
\hline & Cesarian & & \\
\hline Peso ao nascer & - & Quantitativa & \multirow{3}{*}{$\begin{array}{l}\text { Medidas descritivas e tabela de } \\
\text { frequência }\end{array}$} \\
\hline Perímetro cefálico & - & Quantitativa & \\
\hline Tempo de internação & - & Quantitativa & \\
\hline
\end{tabular}


Continuação

\begin{tabular}{|c|c|c|c|}
\hline \multicolumn{2}{|c|}{ Variável } & Classificação & Descrição dos dados \\
\hline \multirow{2}{*}{$\begin{array}{l}\text { Realização de pré-natal } \\
\text { completo }\end{array}$} & Sim & \multirow{2}{*}{ Qualitativa } & \multirow{11}{*}{ Tabela de frequência } \\
\hline & Não & & \\
\hline \multirow{2}{*}{$\begin{array}{l}\text { Diagnóstico de microcefalia } \\
\text { no pré- natal }\end{array}$} & Sim & \multirow{2}{*}{ Qualitativa } & \\
\hline & Não & & \\
\hline \multirow{2}{*}{$\begin{array}{l}\text { Diagnóstico de ZIKA no pré- } \\
\text { natal }\end{array}$} & Sim & \multirow{2}{*}{ Qualitativa } & \\
\hline & Não & & \\
\hline \multirow{2}{*}{ Crise neonatal } & Sim & \multirow{2}{*}{ Qualitativa } & \\
\hline & Não & & \\
\hline \multirow{3}{*}{ Ultrassom Transfontanela } & Calcificação & \multirow{3}{*}{ Qualitativa } & \\
\hline & Malformação & & \\
\hline & Ventriculomegalia & & \\
\hline \multirow{3}{*}{ Ressonância magnética } & Calcificação & \multirow{3}{*}{ Qualitativa } & \multirow{7}{*}{ Tabela de frequência } \\
\hline & Malformação & & \\
\hline & Ventriculomegalia & & \\
\hline \multirow{4}{*}{ Tipo de malformação } & Lisencefalia isolada & \multirow{4}{*}{ Qualitativa } & \\
\hline & Lisencefalia associada & & \\
\hline & Polimicrogiria & & \\
\hline & Outros & & \\
\hline \multirow{6}{*}{$\begin{array}{l}\text { Exame Neurológico de } \\
\text { Hammersmith Neonatal } \\
(\text { HINE- N) }\end{array}$} & Postura e tônus & \multirow{6}{*}{ Quantitativa } & \multirow{6}{*}{$\begin{array}{l}\text { Medidas descritivas } \mathrm{e} \\
\text { tabela de frequência }\end{array}$} \\
\hline & Padrões de tônus & & \\
\hline & Reflexo & & \\
\hline & $\begin{array}{l}\text { Padrões e sinais } \\
\text { anormais }\end{array}$ & & \\
\hline & Comportamento & & \\
\hline & Score total & & \\
\hline
\end{tabular}

Fonte: Pesquisadora.

Conclusão

Para realização da correlação e teste de hipóteses, os dados foram submetidos ao teste de normalidade através do Teste Kolmogorov-Smirnov, o mesmo apontou para uma distribuição anormal dos dados. Assim, para a análise de significância estatística utilizou-se os testes não paramétricos: Spearman's, Teste Qui Quadrato (Teste $X^{2}$ ), Teste de Mann-Whitney (Teste U), para ambas as provas estatísticas aplicadas (Spearman's, Teste $\mathrm{X}^{2}$ e Teste U), considerou-se o intervalo de confiança de $95 \%$. 


\subsection{PROCEDIMENTOS ÉTICOS}

Conforme Resolução 466/12 do Conselho Nacional de Saúde, este estudo foi aprovado pelo Comitê de Ética em Pesquisa (CEP) do HCFMRP- USP em 24 de junho de 2016. Processo 7404- 2016 (ANEXO III) (NOVOA, 2014).

\subsection{COLABORAÇÃO}

Esse trabalho foi realizado com a colaboração das equipes médicas da obstetrícia, pediatria (infecções congênitas e neonatologia), neuroradiologia e neurologia infantil do HCFMRP-USP. 


\section{RESULTADOS}

Participaram deste estudo 30 crianças, que foram acompanhadas pela neurologia infantil do HCFMRP-USP. Destas excluíram-se 12 crianças, 11 crianças em decorrência de não terem sido submetidas à realização do exame neurológico neonatal e uma por não ter realizado RM. Assim, incluíram-se 18 crianças nesta análise de resultados.

\subsection{ANÁLISE DESCRITIVA}

Das 18 crianças, $10(55,6 \%)$ eram do sexo feminino e $8(44,4 \%)$ do sexo masculino. As crianças nasceram de mães com idade gestacional (IG) entre 32 e 42 semanas, média de 38 semanas e seis dias (desvio padrão $\pm 2,26$ ), moda 38 semanas e 8 dias e mediana de 38 semanas e 9 dias. Destas somente uma nasceu pré-termo com 32 semanas, representando $5,6 \%$ da amostra, sendo do sexo feminino e cujo PC era $26,5 \mathrm{~cm}$. Sua idade foi corrigida para aplicação do HINE- N.

Em relação à cidade de origem das genitoras, $12(66,7 \%)$ são do município de Ribeirão Preto e $6(33,3 \%)$ de outros municípios da região, sendo esses: Jardinópolis, Barrinha, São Joaquim da Barra, Nuporanga, Santa Rosa do Viterbo e Serrana.

Identificou-se que o local do nascimento da maioria das crianças, $15(83,3 \%)$ foi o Centro Obstétrico (CO) do HCFMRP-USP e o restante em outros locais, sendo: Maternidade Sinhá Junqueira; Centro de Referência em Saúde da Mulher- MATER; Maternidade de São Joaquim da Barra.

A via de parto predominante no nascimento foi o parto normal $13(72,2 \%)$. O APGAR apresentado pelas $18(100,0 \%)$ crianças nos primeiros cinco minutos pós-parto foi acima de sete.

O peso de nascimento (PN) das crianças foi entre 1228 e 3200 g, média de 2629,9 (desvio padrão $\pm 436,1$ ), moda 2775 e mediana 2682,5. No que se refere ao PC avaliado no momento do nascimento, a medida foi entre 26 e $31,5 \mathrm{~cm}$, média de 28,3 (desvio padrão \pm $1,7)$, moda 30 e mediana 28,5 .

Observou-se que a distribuição dos valores de PC no sexo masculino são superiores aos valores observados no sexo feminino, enquanto o valor total de ambos demonstra tendência decrescente, conforme mostram o gráfico 1 e 2 . 
Gráfico 1. Distribuição do perímetro cefálico (PC) de acordo com o sexo, Ribeirão Preto, 2018.

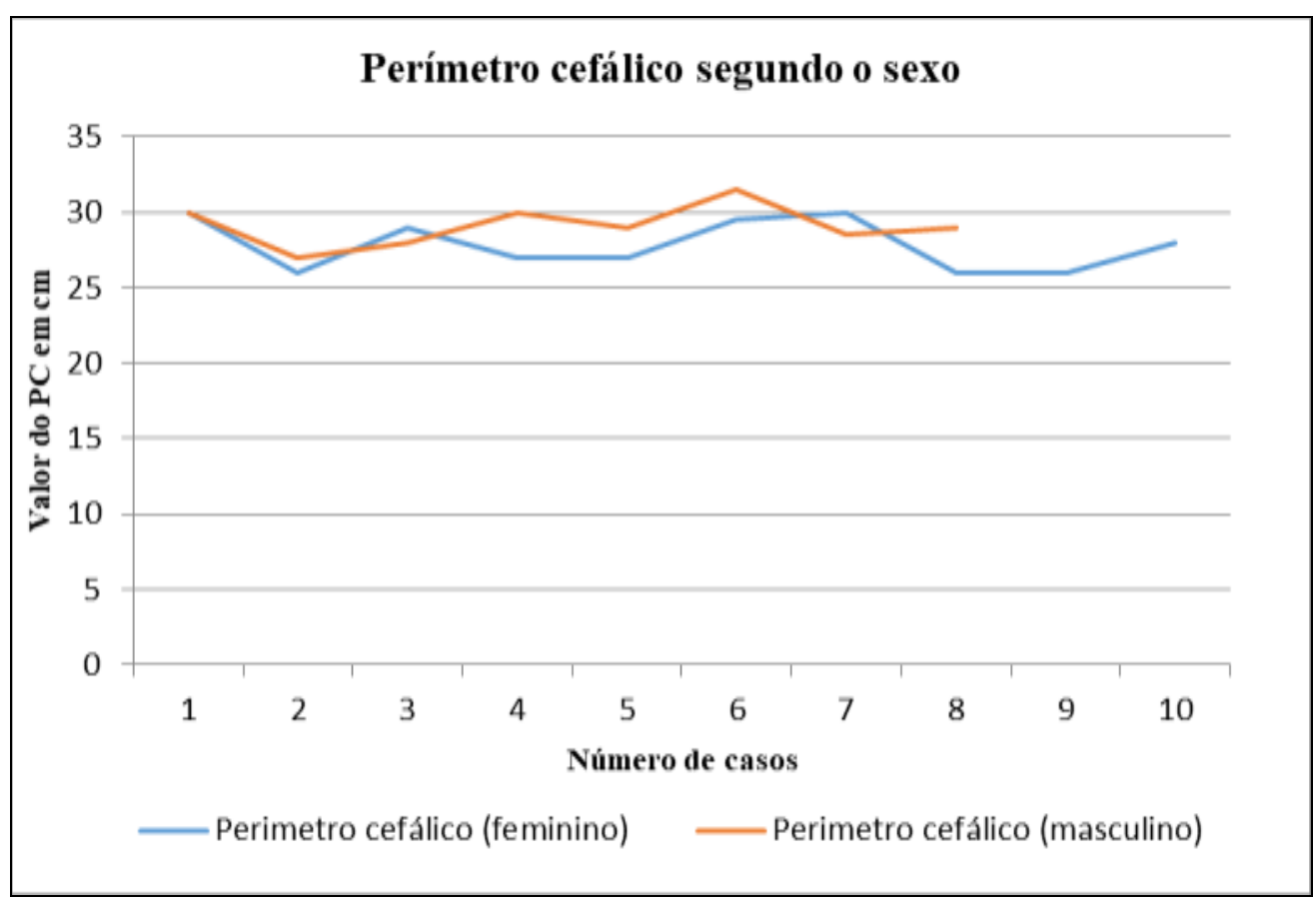

Fonte: Pesquisadora.

Gráfico 2. Dispersão do valor total do perímetro cefálico (PC), Ribeirão Preto, 2018.

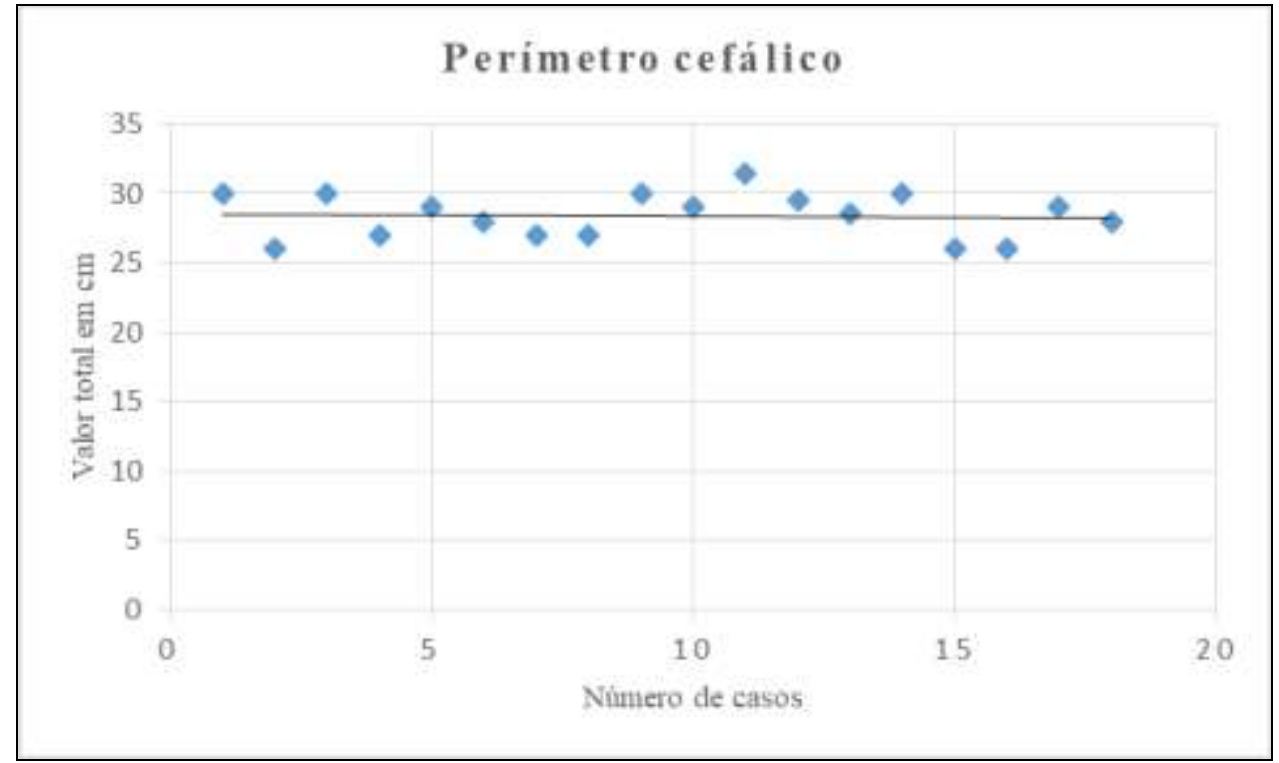

Fonte: Pesquisadora.

Ainda, a superioridade dos valores de PC no sexo masculino é evidenciada conforme as medidas descritivas demonstradas na tabela 1. 
Tabela 1. Distribuição das medidas descritivas do perímetro cefálico (PC) de acordo com o sexo, Ribeirão Preto, 2018.

\begin{tabular}{|c|c|c|c|}
\hline \multicolumn{4}{|c|}{ Perímetro cefálico (PC) } \\
\hline \multicolumn{2}{|c|}{ Masculino } & \multicolumn{2}{|c|}{ Feminino } \\
\hline Mínimo & 27,0 & Mínimo & 26,0 \\
\hline Máximo & 31,5 & Máximo & 30,0 \\
\hline Média & 29,1 & Média & 27,7 \\
\hline Desvio padrão & $\pm 1,4$ & Desvio padrão & $\pm 1,7$ \\
\hline Moda & 30,0 & Moda & 26,0 \\
\hline Mediana & 29,0 & Mediana & 27,0 \\
\hline
\end{tabular}

Fonte: Pesquisadora.

Identificou-se que $15(83,3 \%)$ genitoras realizaram o pré-natal completo.

Durante o pré-natal foi diagnosticado microcefalia e infecção pelo ZIKV, conforme mostra a tabela 2 .

Tabela 2. Distribuição dos diagnósticos de microcefalia e infecção por ZIKA vírus no pré-natal, Ribeirão Preto, 2018.

\begin{tabular}{cccccc}
\hline \multirow{2}{*}{ Descrição } & \multicolumn{2}{c}{ Diagnóstico pré-natal } & & \multicolumn{2}{c}{ Diagnóstico pré-natal } \\
& $\mathbf{2}$ & microcefalia & & \multicolumn{2}{c}{ ZIKA } \\
& $\mathbf{N}$ & 72,2 & 12 & $\%$ \\
\hline Sim & 13 & 27,8 & 06 & 66,7 \\
Não & 05 & $\mathbf{n}$ & 33,3 \\
Total & $\mathbf{1 8}$ & $\mathbf{1 0 0 , 0}$ & $\mathbf{1 8}$ & $\mathbf{1 0 0 , 0}$ \\
\hline
\end{tabular}

n=frequência e \% porcentagem

Fonte: Pesquisadora.

Houve crise neonatal em $14(77,8 \%)$ das crianças. O tempo de internação dessas variou entre 3 e 53 dias, média de 12,5 (desvio padrão \pm 13,2), moda 5 e mediana 8,5.

Pelo exame de US verificaram-se as seguintes alterações: calcificação, malformação e ventriculomegalia, distribuídas conforme mostra a tabela 3 . 
Tabela 3. Distribuição das alterações evidenciadas no exame de ultrassom, Ribeirão Preto, 2018.

\begin{tabular}{lcc}
\hline Alterações & $\mathbf{n}$ & $\mathbf{\%}$ \\
\hline Calcificação & 13 & 72,2 \\
Sim & 05 & 27,8 \\
Ignorado & $\mathbf{1 8}$ & $\mathbf{1 0 0 , 0}$ \\
Total & & \\
Malformação & 11 & 61,1 \\
Sim & 02 & 11,1 \\
Não & 05 & 27,8 \\
Ignorado & $\mathbf{1 8}$ & $\mathbf{1 0 0 , 0}$ \\
Total & & \\
Ventriculomegalia & 12 & 66,7 \\
Sim & 01 & 5,6 \\
Não & 05 & 27,8 \\
Ignorado & $\mathbf{1 8}$ & $\mathbf{1 0 0 , 0}$ \\
Total & & \\
\hline
\end{tabular}

n=frequência e \% porcentagem

Fonte: Pesquisadora.

Pela RM foram identificadas alterações, conforme mostra a tabela 4.

Tabela 4. Distribuição das alterações evidenciadas no exame de ressonância magnética, Ribeirão Preto, 2018.

\begin{tabular}{lrr}
\hline Alterações & n & \multicolumn{1}{c}{$\%$} \\
\hline Calcificação & 16 & 88,9 \\
Sim & 02 & 11,1 \\
Mão & $\mathbf{1 8}$ & $\mathbf{1 0 0 , 0}$ \\
Total & & \\
Ventriculomegalia & 17 & 94,44 \\
Sim & 01 & 5,56 \\
Não & $\mathbf{1 8}$ & $\mathbf{1 0 0 , 0}$ \\
Total & & \\
Malformação cortical & & \\
Sim & 18 & 100,00 \\
Total & $\mathbf{1 8}$ & $\mathbf{1 0 0 , 0}$ \\
\hline
\end{tabular}

n=frequência e \% porcentagem

Fonte: Pesquisadora. 
Os tipos de MDC identificados pela ressonância estão demonstrados na tabela 5.

Tabela 5. Distribuição do tipo de malformação do desenvolvimento cortical evidenciada por meio de ressonância magnética, Ribeirão Preto, 2018.

\begin{tabular}{lcc}
\hline Tipo de malformação & $\mathbf{n}$ & $\mathbf{\%}$ \\
\hline Lisencefalia isolada & 08 & 44,4 \\
Lisencefalia associada & 06 & 33,3 \\
Polimicrogiria & 02 & 11,1 \\
Outros & 02 & 11,1 \\
Total & $\mathbf{1 8}$ & $\mathbf{1 0 0 , 0}$ \\
\hline
\end{tabular}

n=frequência e \% porcentagem

Fonte: Pesquisadora.

Na avaliação HINE- N, identificou-se oscilações nas avaliações em relação ao gênero. No HINE N- postura e tônus, e padrões de tônus, padrões e sinais anormais e comportamento o sexo masculino obteve melhores resultados que o sexo feminino, enquanto no HINE N- reflexo e movimentos o sexo feminino teve maior pontuação.

A tabela 6 e 7 mostram as distribuições do HINE N nos domínios postura e tônus, padrões de tônus, reflexos, movimentos, padrões e sinais anormais e comportamento distribuídos por sexo.

Tabela 6. Distribuição do Exame Neurológico de Hammersmith Neonatal em relação à postura e tônus, padrões e tônus, reflexos e movimentos de acordo com o sexo, Ribeirão Preto, 2018.

Continua

\begin{tabular}{lcccc}
\hline \multirow{2}{*}{ SEXO } & \multicolumn{4}{c}{ HINE- N } \\
\cline { 2 - 5 } & $\begin{array}{c}\text { Postura e } \\
\text { tônus }\end{array}$ & $\begin{array}{c}\text { Padrões de } \\
\text { tônus }\end{array}$ & Reflexos & Movime \\
\hline Feminino & & & & \\
Avaliados & 10 & 10 & 10 & 10 \\
Minímo & 01 & 03 & 00 & 00 \\
Máximo & 9,5 & 05 & 01 & 03 \\
Média & 6,3 & 4,0 & 0,8 & 1,7 \\
Desvio padrão & $\pm 2,8$ & $\pm 0,7$ & $\pm 0,4$ & $\pm 1,1$ \\
Mediana & 07 & 04 & 01 & 1,7 \\
Moda & 8,5 & 04 & 01 & 0,5
\end{tabular}


Continuação

\begin{tabular}{lcccc}
\hline \multirow{2}{*}{ SEXO } & \multicolumn{4}{c}{ HINE N } \\
\cline { 2 - 5 } & $\begin{array}{c}\text { Postura e } \\
\text { tônus }\end{array}$ & $\begin{array}{c}\text { Padrões de } \\
\text { tônus }\end{array}$ & Reflexos & Movimentos \\
\hline Maculino & 08 & 08 & 08 & 08 \\
Avaliados & 2,5 & 03 & 00 & 00 \\
Minímo & 08 & 05 & 01 & 03 \\
Máximo & 06 & 4,25 & 0,75 & 1,44 \\
Média & $\pm 2,00$ & $\pm 0,71$ & $\pm 0,46$ & $\pm 0,86$ \\
Desvio padrão & 6,5 & 04 & 01 & 1,5 \\
Mediana & 6,5 & 04 & 01 & 1,5 \\
Moda & & & 01 & \\
\hline
\end{tabular}

Score HINE- N: mínimo 5; máximo 26; média de 17,2 (desvio padrão $\pm 6,21$ ); moda (não calculada, pois não houve score de igualdade); mediana 17.

Fonte: Pesquisador.

Conclusão

Pode- se observar que a média de pontuação com relação aos reflexos tendíneos foi de $80 \%$ do esperado para meninas e $75 \%$ para meninos, à custa da presença de reflexos muito ativos ou clônus. Não houve nenhum caso de artrogripose nesta série.

Tabela 7. Distribuição do Exame Neurológico de Hammersmith Neonatal em relação aos padrões e sinais anormais e comportamento de acordo com o sexo, Ribeirão Preto, 2018.

Continua

\begin{tabular}{lcc}
\hline & \multicolumn{2}{c}{ HINE N } \\
\cline { 2 - 3 } \multicolumn{1}{c}{ SEXO } & Padrões e sinais anormais & Comportamento \\
\hline Feminino & 10 & 10 \\
Avaliados & 00 & 00 \\
Minímo & 03 & 6,5 \\
Máximo & 1,2 & 3,2 \\
Média & $\pm 1,2$ & $\pm 2,2$ \\
Desvio padrão & 01 & 03 \\
Mediana & 00 & 03 \\
Moda & &
\end{tabular}




\section{HINE N}

\section{SEXO}

Padrões e sinais anormais

\section{Comportamento}

\section{Maculino}

Avaliados

08

08

Minímo

00

00

Máximo

03

6,5

Média

1,6

04

Desvio padrão

$\pm 1,1$

$\pm 2,2$

Mediana

1,5

4,2

Moda

01

6,5

Score HINE- N: mínimo 5; máximo 26; média de 17,2 (desvio padrão $\pm 6,21$ ); moda (não calculada, pois não houve score de igualdade); mediana 17.

Fonte: Pesquisador.

Conclusão

As oscilações do score HINE- N- total apresentam são apresentados no gráfico 3.

Gráfico 3. Dispersão do score total do Exame Neurológico de Hammersmith Neonatal, Ribeirão Preto, 2018.

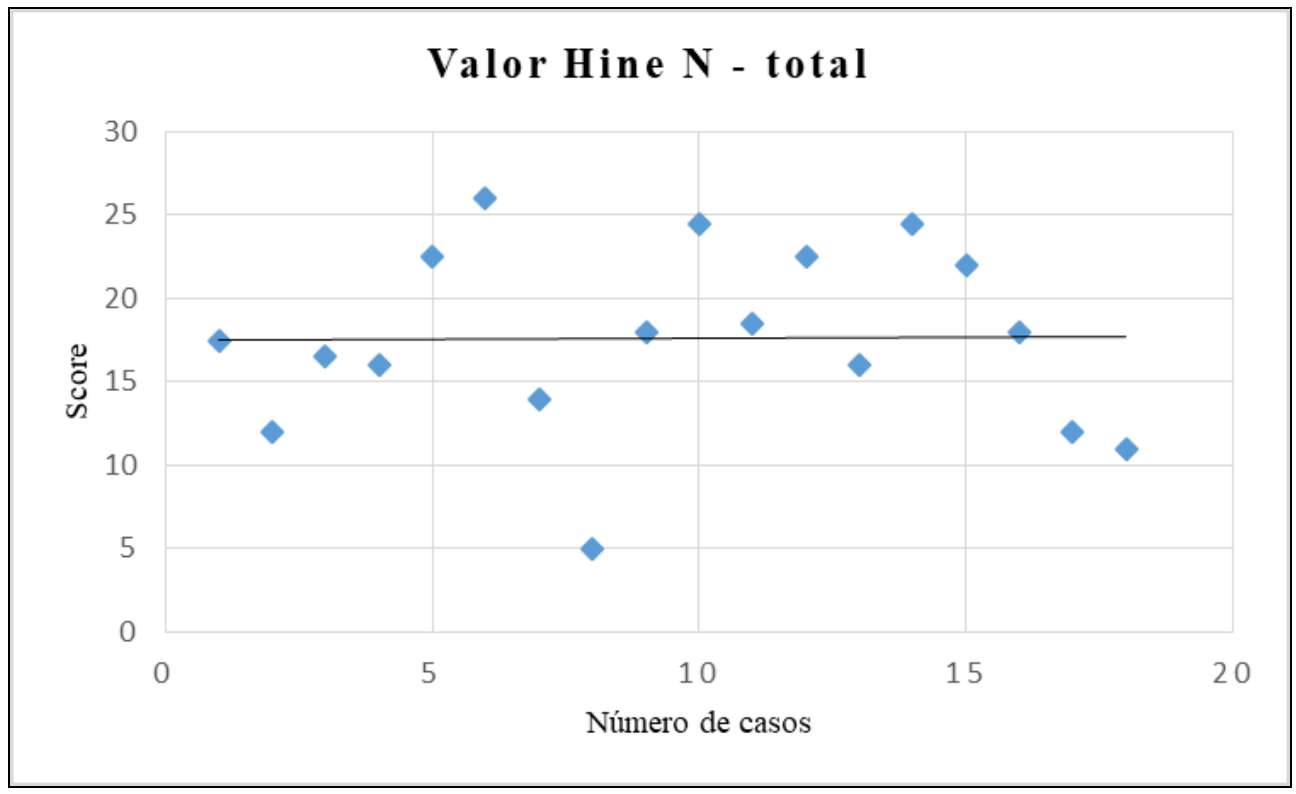

Fonte: Pequisadora

As medidas descritivas dos valores dos domínios HINE- N - postura e tônus, padrões de tônus, reflexos, movimentos, padrões e sinais anormais e comportamento estão demonstradas na tabela 8 . 
Tabela 8. Medidas descritivas dos domínios do Exame Neurológico de Hammersmith Neonatal, Ribeirão Preto, 2018.

\begin{tabular}{lcccccc}
\hline \multicolumn{1}{c}{ Domínio HINE- N } & Mínimo & Máximo & Média & $\begin{array}{c}\text { Desvio } \\
\text { padrão }\end{array}$ & Moda & Mediana \\
& & \multicolumn{3}{c}{} & & \\
\hline Postura e tônus & 1,0 & 9,5 & 6,4 & $\pm 2,4$ & 6,5 & 6,5 \\
Padrões de tônus & 3,0 & 5,0 & 4,1 & $\pm 0,7$ & 4,0 & 4,0 \\
Reflexos & 0 & 1,0 & 0,8 & $\pm 0,4$ & 1,0 & 1,0 \\
Movimentos & 0 & 3,0 & 1,6 & $\pm 0,1$ & 1,5 & 1,5 \\
Padrões e sinais anormais & 0 & 3,0 & 1,4 & $\pm 1,2$ & 1,0 & 1,0 \\
Comportamento & 0 & 6,5 & 3,6 & $\pm 2,2$ & 3,0 & 3,5 \\
\hline
\end{tabular}

Fonte: Pesquisadora.

\subsection{ANÁLISE DE SIGNIFICÂNCIA ESTATÍSTICA}

$\mathrm{Na}$ análise de correlações não se identificou significância estatística na avaliação do PC e das variáveis HINE- N - total, PN, APGAR e tempo de internação, indicando ausência de relação entre as variáveis.

Verificou-se associação entre a variável PC e presença de crise neonatal $(\mathrm{p}=0,046<0,05)$ e ausência e associação entre o PC e presença de ventriculomegalia, calcificação e malformações na RM ou no USTF, conforme mostra a tabela 9.

Tabela 9. Associação entre o perímetro cefálico e as variáveis: presença de crise, presença de ventriculomegalia, calcificação e malformações na ressonância magnética e no ultrassom transfontanela. Ribeirão Preto, 2018.

\begin{tabular}{lc}
\hline \multicolumn{1}{c}{ Variáveis } & p-valor \\
\hline PC X Crise convulsiva & $0,046^{*}$ \\
PC X RM ventriculomegalia & 0,222 \\
PC X RM calcificação & 0,118 \\
PC X RM malformações & Constante \\
PC X US ventriculomegalia & 0,335 \\
PC X US calcificação & 0,849 \\
PC X US malformações & 0,791 \\
\hline
\end{tabular}

* Teste $U$, significância valor de $p<$ ou $=0,05$.

Fonte: Pesquisadora.

Houve ausência de associação entre o PC e diagnóstico pré-natal de infecção congênita pelo ZIKV ( $\mathrm{p}=0,494>0,05)$. No entanto, há associação entre o pré-natal completo e 
incompleto e as variáveis: cidade de residência, local de nascimento, diagnóstico de microcefalia no pré-natal, diagnóstico de infecção por ZIKV no pré-natal e tipo de parto, conforme mostra a tabela 10 .

Tabela 10. Associação do pré-natal as variáveis: cidade de residência, local de nascimento, diagnóstico de microcefalia no pré-natal, diagnóstico de Zika no pré-natal, tipo de parto. Ribeirão Preto, 2018.

\begin{tabular}{lc}
\hline \multicolumn{1}{c}{ Variáveis } & p- valor \\
\hline Pré-natal X Cidade de residência & $0,000^{*}$ \\
Pré-natal X Local de nascimento & $0,001^{*}$ \\
Pré-natal X Diagnóstico de microcefalia no pré-natal & $0,000^{*}$ \\
Pré-natal X Diagnóstico de infecção pelo ZIKV no pré-natal & $0,000^{*}$ \\
Pré-natal X Tipo de parto & $0,001^{*}$
\end{tabular}

* Teste $\mathrm{X}^{2}$, significância valor de $\mathbf{p}<\mathrm{ou}=\mathbf{0 , 0 0 1}$.

Fonte: Pesquisadora.

Não houve associação entre o pré-natal completo e incompleto e as variáveis: IG, PN, tempo de internação e HINE- N-total, conforme mostra a tabela 11.

Tabela 11. Associação do pré-natal e as variáveis: idade gestacional, peso de nascimento, tempo de internação, Exame Neurológico de Hammersmith Neonatal- total. Ribeirão Preto, 2018.

\begin{tabular}{lc}
\hline \multicolumn{1}{c}{ Variáveis } & p- valor \\
\hline Pré-natal X Idade gestacional & 0,127 \\
Pré-natal X Peso de nascimento & 0,654 \\
Pré-natal X Tempo de internação & 0,738 \\
Pré-natal X Hine N - total & 0,498
\end{tabular}

* Teste U, significância valor de $\mathbf{p}<$ ou $=0,05$.

Fonte: Pesquisadora.

Na tabela 12, observa-se a ausência de associação entre a presença ou não de crise neonatal e variáveis: IG, PN, tempo de internação, HINE- N - total. Logo, manteve-se a significância estatística já evidenciada entre presença ou não de crise neonatal o $P C(p=0,46$, ou seja, $\mathrm{p}<0,05)$. 
Tabela 12. Associação da variável crise neonatal e suas categorias e as variáveis: idade gestacional, peso de nascimento, tempo de internação e Exame Neurológico de Hammersmith Neonatal - total. Ribeirão Preto, 2018.

\begin{tabular}{lc}
\hline \multicolumn{1}{c}{ Variáveis } & p- valor \\
\hline Crise neonatal X Idade gestacional & 0,127 \\
Crise neonatal X Peso de nascimento & 0,878 \\
Crise neonatal X Tempo de internação & 0,192 \\
Crise neonatal X Hine N - total & 1,000 \\
\hline
\end{tabular}

* Teste $\mathrm{U}$, significância valor de $\mathrm{p}<\mathrm{ou}=\mathbf{0 , 0 5}$.

Fonte: Pesquisadora.

Não houve associação entre crise neonatal e as variáveis: local de nascimento, tipo de parto, ventriculomegalia, calcificação e malformação no USTF, conforme mostra a tabela 13.

Tabela 13. Associação entre crise neonatal e as variáveis: local de nascimento, tipo de parto, ventriculomegalia, calcificação e malformação no ultrassom transfontanela. Ribeirão Preto, 2018.

\begin{tabular}{lc}
\hline \multicolumn{1}{c}{ Variáveis } & p-valor \\
\hline Crise neonatal X Local de nascimento & 0,005 \\
Crise neonatal X Tipo de parto & 0,059 \\
Crise neonatal X US ventriculomegalia & 0,157 \\
Crise neonatal X US calcificação & 0,059 \\
Crise neonatal X US malformação & 0,346
\end{tabular}

* Teste $\mathrm{X}^{2}$, significância valor $\mathrm{de} \mathbf{p}<\mathrm{ou}=0,001$.

Fonte: Pesquisadora.

Houve associação entre crise convulsiva neonatal e a presença de ventriculomegalia na RM e calcificação na RM, conforme mostra a tabela 14 .

Tabela 14. Associação crise neonatal e as variáveis: ventriculomegalia, calcificação e malformação na ressonância magnética. Ribeirão Preto, 2018.

\begin{tabular}{lc}
\hline \multicolumn{1}{c}{ Variáveis } & p-valor \\
\hline Crise convulsiva X RM ventriculomegalia & $0,000^{*}$ \\
Crise convulsiva X RM calcificação & $0,001^{*}$ \\
Crise convulsiva X RM malformação & Constante
\end{tabular}

* Teste $X^{2}$, significância valor de $p<o u=0,001$.

Fonte: Pesquisadora.

Não houve associação entre diagnóstico pré- natal de infecção pelo ZIKV ou de microcefalia no pré-natal e as variáveis: IG, perímetro cefálico, tempo de internação, score HINE- N - total, conforme as tabelas 15 e 16. 
Tabela 15. Associação entre diagnóstico pré- natal de infecção pelo vírus da ZIKA e as variáveis: idade gestacional, perímetro cefálico, tempo de internação e score total do Exame Neurológico de Hammersmith Neonatal. Ribeirão Preto, 2018.

\begin{tabular}{lc}
\hline \multicolumn{1}{c}{ Variáveis } & p-valor \\
\hline Diagnóstico de infecção pelo ZIKV X IG & 0,385 \\
Diagnóstico de infecção pelo ZIKV X PC & 0,494 \\
Diagnóstico de infecção pelo ZIKV X Tempo de internação & 0,964 \\
Diagnóstico de infecção pelo ZIKV X Score Hine N - total & 0,892
\end{tabular}

* Teste $\mathrm{U}$, significância valor de $\mathrm{p}<\mathrm{ou}=0,05$.

Fonte: Pesquisadora.

Tabela 16. Associação entre diagnóstico pré- natal de microcefalia e as variáveis: idade gestacional, perímetro cefálico, tempo de internação e score total no Exame Neurológico de Hammersmith Neonatal. Ribeirão Preto, 2018.

\begin{tabular}{lc}
\hline \multicolumn{1}{c}{ Variáveis } & p-valor \\
\hline Diagnóstico de microcefalia X IG & 0,246 \\
Diagnóstico de microcefalia X PC & 0,143 \\
Diagnóstico de microcefalia X Tempo de internação & 0,849 \\
Diagnóstico de microcefalia X Score Hine N - total & 0,703 \\
\hline
\end{tabular}

*Teste U, significância valor de $\mathrm{p}<\mathrm{ou}=0,05$.

Fonte: Pesquisadora.

Não se observou associação entre diagnóstico pré- natal de infecção pelo ZIKV ou de microcefalia no pré-natal e as variáveis: cidade de residência, local de nascimento e tipo de parto, conforme mostra as tabelas 17 e 18 .

Tabela 17. Associação entre diagnóstico pré- natal de infecção pelo vírus da ZIKA e as variáveis: cidade de residência, local de nascimento e tipo de parto. Ribeirão Preto, 2018.

\begin{tabular}{lc}
\hline \multicolumn{1}{c}{ Variáveis } & p-valor \\
\hline Diagnóstico de infecção pelo ZIKV X Cidade de residência & 0,157 \\
Diagnóstico de infecção pelo ZIKV X Local de nascimento & 0,005 \\
Diagnóstico de infecção pelo ZIKV X Tipo de parto & 0,059 \\
\hline
\end{tabular}

* Teste $\mathrm{X}^{2}$, significância valor de $\mathrm{p}<\mathrm{ou}=0,001$.

Fonte: Pesquisadora. 
Tabela 18. Associação entre o diagnóstico pré- natal de microcefalia e as variáveis: cidade de residência, local de nascimento e tipo de parto. Ribeirão Preto, 2018.

\begin{tabular}{lc}
\hline \multicolumn{1}{c}{ Variáveis } & p-valor \\
\hline Diagnóstico de microcefalia X Cidade de residência & 0,157 \\
Diagnóstico de microcefalia X Local de nascimento & 0,005 \\
Diagnóstico de microcefalia X Tipo de nascimento & 0,059 \\
\hline
\end{tabular}

* Teste $\mathrm{X}^{2}$, significância valor de $\mathrm{p}<\mathrm{ou}=0,001$.

Fonte: Pesquisadora.

Não houve correlação entre HINE- N - total e as variáveis: IG, PC, PN e tempo de internação, conforme mostra a tabela 19.

Tabela 19. Correlação score total no Exame Neurológico de Hammersmith Neonatal e as variáveis: idade gestacional, perímetro cefálico, peso de nascimento, APGAR e tempo de internação. Ribeirão Preto, 2018.

\begin{tabular}{lc}
\hline \multicolumn{1}{c}{ Variáveis } & p- valor \\
\hline Hine N- total X IG & 0,514 \\
Hine N- total X PC & 0,337 \\
Hine N- total X PN & 0,930 \\
Hine N- total X APGAR & Constante \\
Hine N- total X Tempo de internação & 0,210 \\
\hline * Teste de Spearman, significância valor de $\mathbf{p}<\mathbf{o u}=\mathbf{0 , 0 0 1 .}$ \\
Fonte: Pesquisadora
\end{tabular}

Não houve associação entre HINE- N - total e as variáveis: sexo, local de nascimento, tipo de parto, presença de crise neonatal, prematuridade extrema, ventriculomegalia, calcificação e malformação na RM ou USTF e tipo de malformação na RM, conforme mostra tabela 20 . 
Tabela 20. Associação entre o score total do Exame Neurológico de Hammersmith Neonatal e as variáveis: sexo, local de nascimento, tipo de parto, presença de crise neonatal, prematuridade extrema, ventriculomegalia, calcificação e malformação na ressonância magnética ou ultrassom transfontanela e tipo de malformação na ressonância magnética. Ribeirão Preto, 2018.

\begin{tabular}{lc}
\hline \multicolumn{1}{c}{ Variáveis } & p- valor \\
\hline Hine N- total X Sexo & 0,829 \\
Hine N- total X Local de nascimento & 0,912 \\
Hine N- total X Tipo de parto & 0,143 \\
Hine N- total X Crise neonatal & 1,000 \\
Hine N- total X Prematuridade extrema & 0,556 \\
Hine N- total X Ventriculomegalia & 0,111 \\
Hine N- total X Calcificação & 0,732 \\
Hine N- total X Malformação & Constante \\
Hine N- total X Tipo de malformação & 0,616 \\
\hline
\end{tabular}

* Teste $\mathbf{X}^{2}$, significância valor de $\mathbf{p}<0 u=0,001$.

Fonte: Pesquisadora.

Não houve associação entre crise convulsiva e os domínios do HINE- N postura e tônus, padrões de tônus, reflexos, movimentos, padrões e sinais anormais, comportamento e score total, conforme mostra a tabela 21.

Tabela 21. Associação entre crise convulsiva e os domínios do Exame Neurológico de Hammersmith Neonatal- postura e tônus, padrões de tônus, reflexos, movimentos, padrões e sinais anormais, comportamento e total. Ribeirão Preto, 2018.

\begin{tabular}{lc}
\hline \multicolumn{1}{c}{ Variáveis } & p- valor \\
\hline Crise convulsiva X HINE - N postura e tônus & 1,000 \\
Crise convulsiva X HINE - N padrão de tônus & 0,721 \\
Crise convulsiva X HINE - N reflexos & 0,442 \\
Crise convulsiva X HINE - N movimentos & 0,798 \\
Crise convulsiva X HINE - N padrões e sinais anormais & 0,798 \\
Crise convulsiva X HINE - N comportamento & 0,959 \\
Crise convulsiva X HINE - N score total & 1,000 \\
\hline
\end{tabular}

*Teste U, significância valor de $p<$ ou $=0,05$.

Fonte: Pesquisadora.

Não houve associação entre o tipo de MFSNC e crise neonatal após aplicação do teste $\mathrm{X}^{2}(\mathrm{p}=0,027>0,001)$.

Não foi observada relação entre tipo de malformação MFSNC e as variáveis: PC, PN, HINE- N - score total e os domínios postura e tônus, padrões de tônus, reflexos, movimentos, padrões e sinais anormais, comportamento, conforme mostra a tabela 22. 
Tabela 22. Associação entre tipo de malformação do sistema nervoso central as variáveis: PC, PN, Exame Neurológico de Hammersmith Neonatal- score total e os dominios postura e tônus, padrões de tônus, reflexos, movimentos, padrões e sinais anormais, comportamento. Ribeirão Preto, 2018.

\begin{tabular}{lc}
\hline \multicolumn{1}{c}{ Variáveis } & p- valor \\
\hline Tipo de malformação X PC & 1,000 \\
Tipo de malformação X PN & 0,563 \\
Tipo de malformação X HINE - N score total & 0,228 \\
Tipo de malformação X HINE - N postura e tônus & 0,428 \\
Tipo de malformação X HINE - N padrão de tônus & 0,365 \\
Tipo de malformação X HINE - N reflexos & 0,349 \\
Tipo de malformação X HINE - N movimentos & 0,285 \\
Tipo de malformação X HINE - N padrões e sinais & \\
anormais & 0,441 \\
Tipo de malformação X HINE - N comportamento & 0,630 \\
\hline
\end{tabular}

*Teste $U$, significância valor de $p<o u=0,05$.

Fonte: Pesquisadora.

Identificou-se relação entre as variáveis ventriculomegalia na RM e no USTF, calcificação na RM e no USTF e malformação na RM e no USTF, conforme mostram os valores de p na tabela 23.

Tabela 23. Associação entre as variáveis ventriculomegalia na ressonância magnética e no ultrassom transfontanela, calcificação na ressonância magnética e no ultrassom transfontanela e malformação na ressonância magnética e no ultrassom transfontanela, Ribeirão Preto, 2018.

\begin{tabular}{lc}
\hline \multicolumn{1}{c}{ Variáveis } & p-valor \\
\hline RM ventriculomegalia X US ventriculomegalia & 0,001 \\
RM calcificação X US calcificação & 0,000 \\
RM malformação X US malformação & 0,000
\end{tabular}

*Teste $\mathrm{X}^{2}$ Sigificância valor de $\mathrm{p}<\mathrm{ou}=0,001$.

Fonte: Pesquisadora.

Não se evidenciou relação entre HINE N- score total e o tipo de malformação, conforme mostra a tabela 24 . 
Tabela 24. Associação entre Exame Neurológico de Hammersmith Neonatal - total e o tipo de malformação (lisencefalia isolada, lisencefalia associada, polimicrogiria e outros). Ribeirão Preto, 2018.

\begin{tabular}{lc}
\hline \multicolumn{1}{c}{ Variáveis } & p-valor \\
\hline HINE N-total X Lisencefalia isolada & 0,560 \\
HINE N-total X Lisencefalia associada & 0,573 \\
HINE N-total X Polimicrogiria & 0,121 \\
HINE N-total X Outros & 0,333
\end{tabular}

*Teste $U$, significância valor de $p<$ ou $=0,05$.

Fonte: Pesquisadora.

Avaliando o score HINE- N, com 0 para ruim, 0,5 para regular e 1 para bom, realizouse uma relação de percentuais e foi aplicado o parâmetro de comparação dentro de cada subitem.

Considerou-se como fator de risco, os itens cujo número de crianças que pontuaram 0 foi maior ou igual àquelas que pontuaram 0,5 e 1 .

Assim, os domínios encontrados foram reflexos tendíneos, movimentos espontâneosqualitativo, tremor, susto, alerta, irritabilidade, tônus flexor 2, orientação visual e choro, sendo este um achado significativo nos resultados. 


\subsection{IMAGENS}

Imagens 1. Caso 1, sexo masculino. Ausência de calcificações, presença de ventriculomegalia, lisencefalia e paquigiria. Ribeirão Preto, 2018.

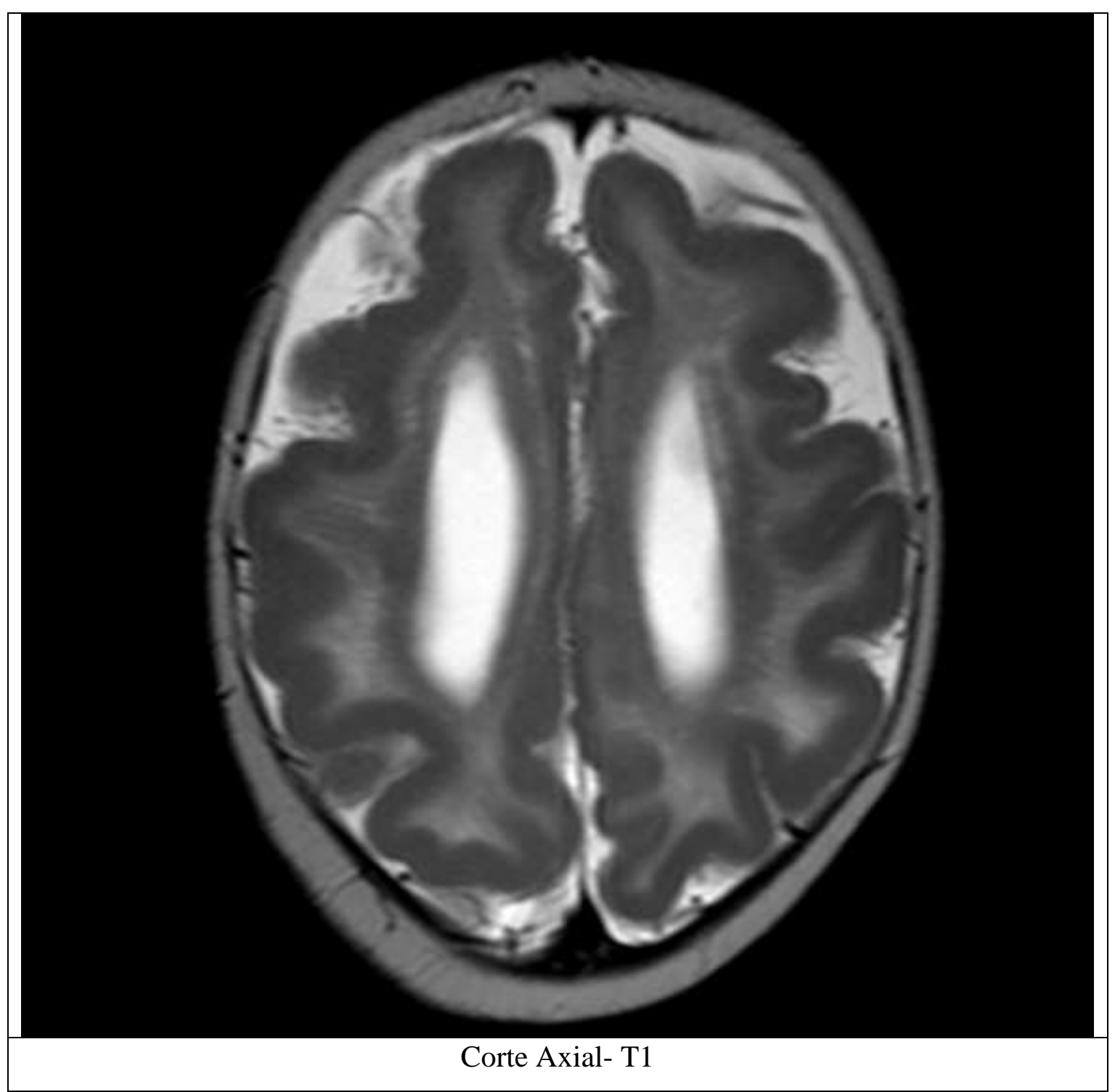




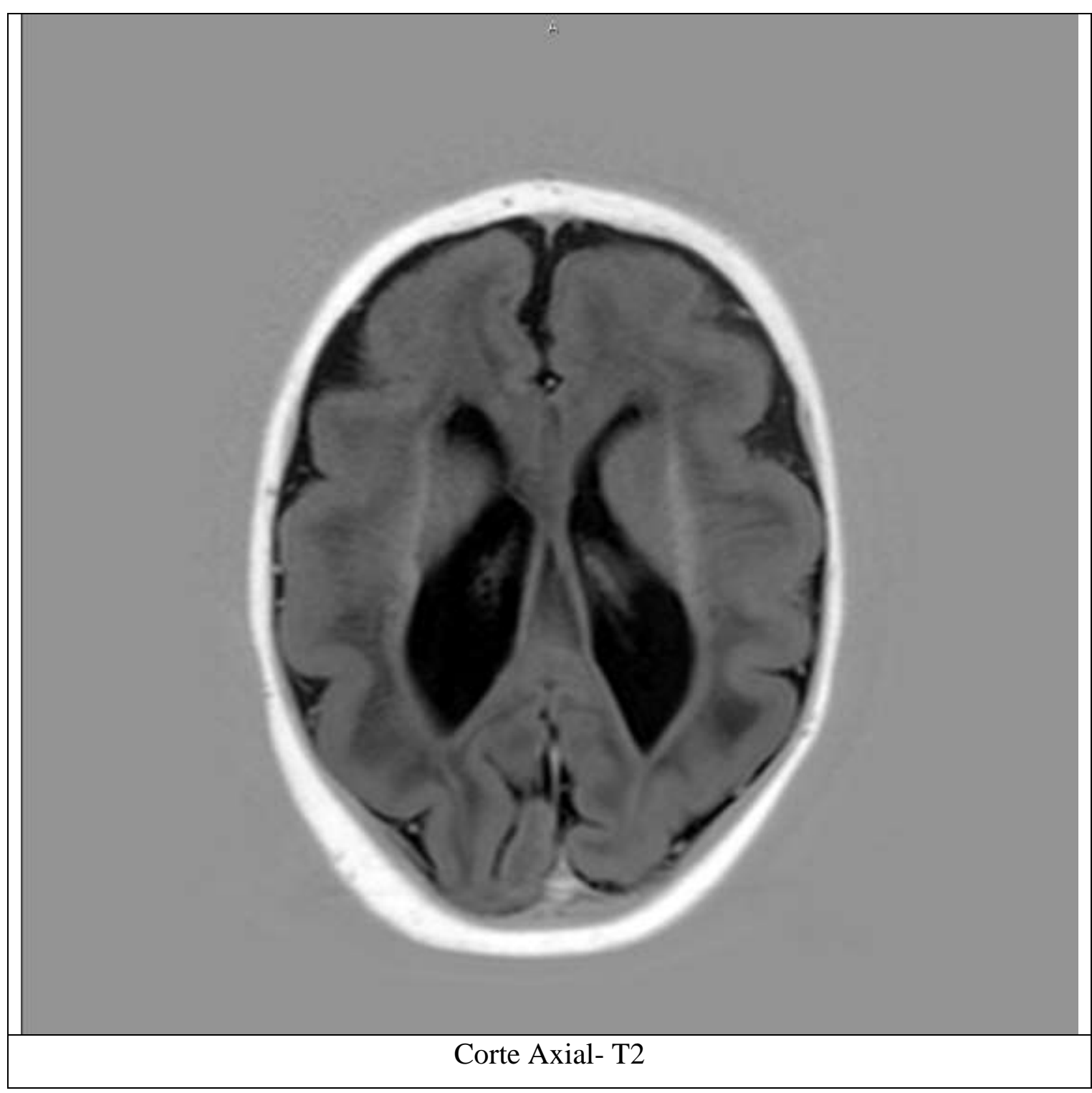




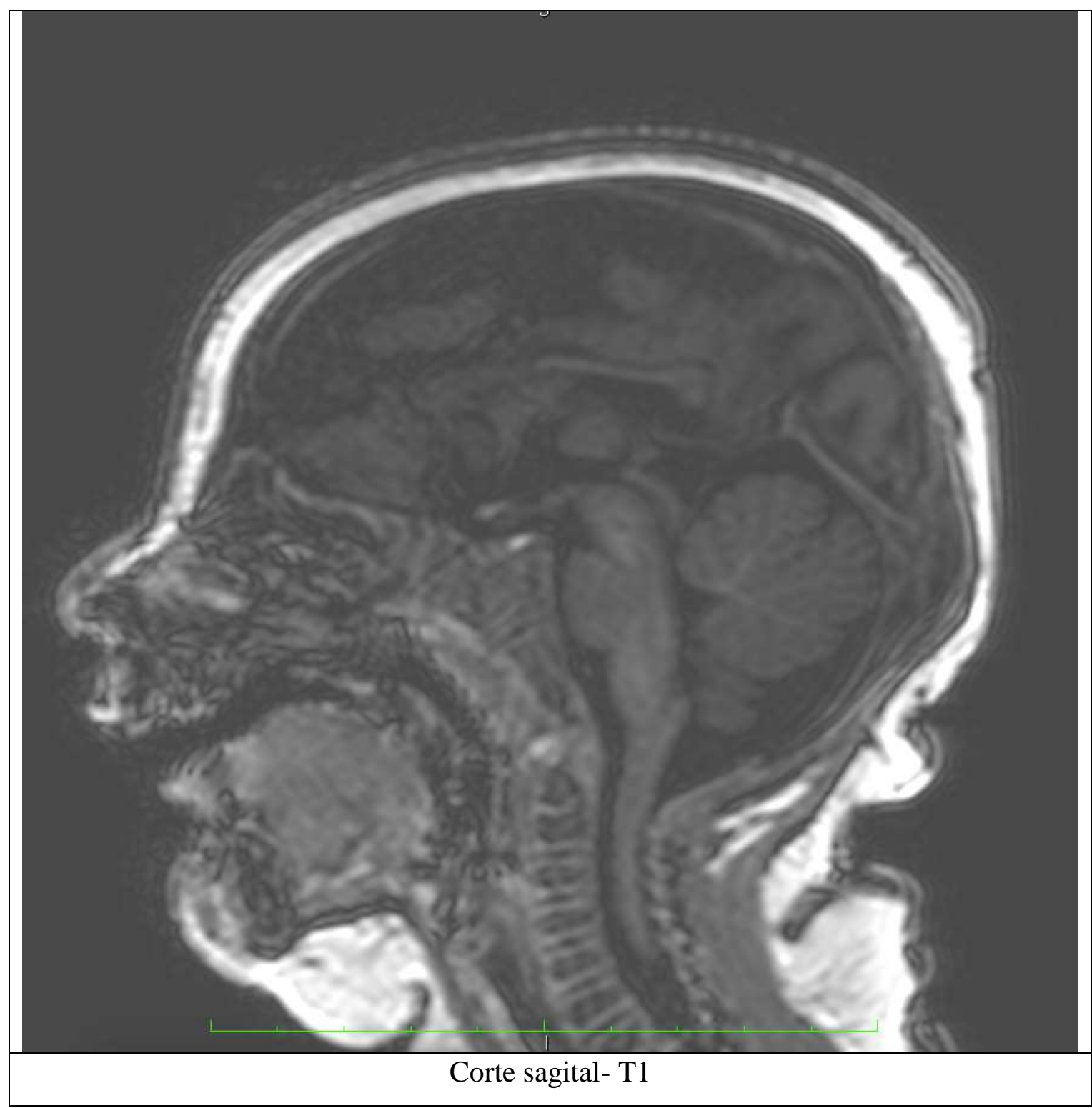




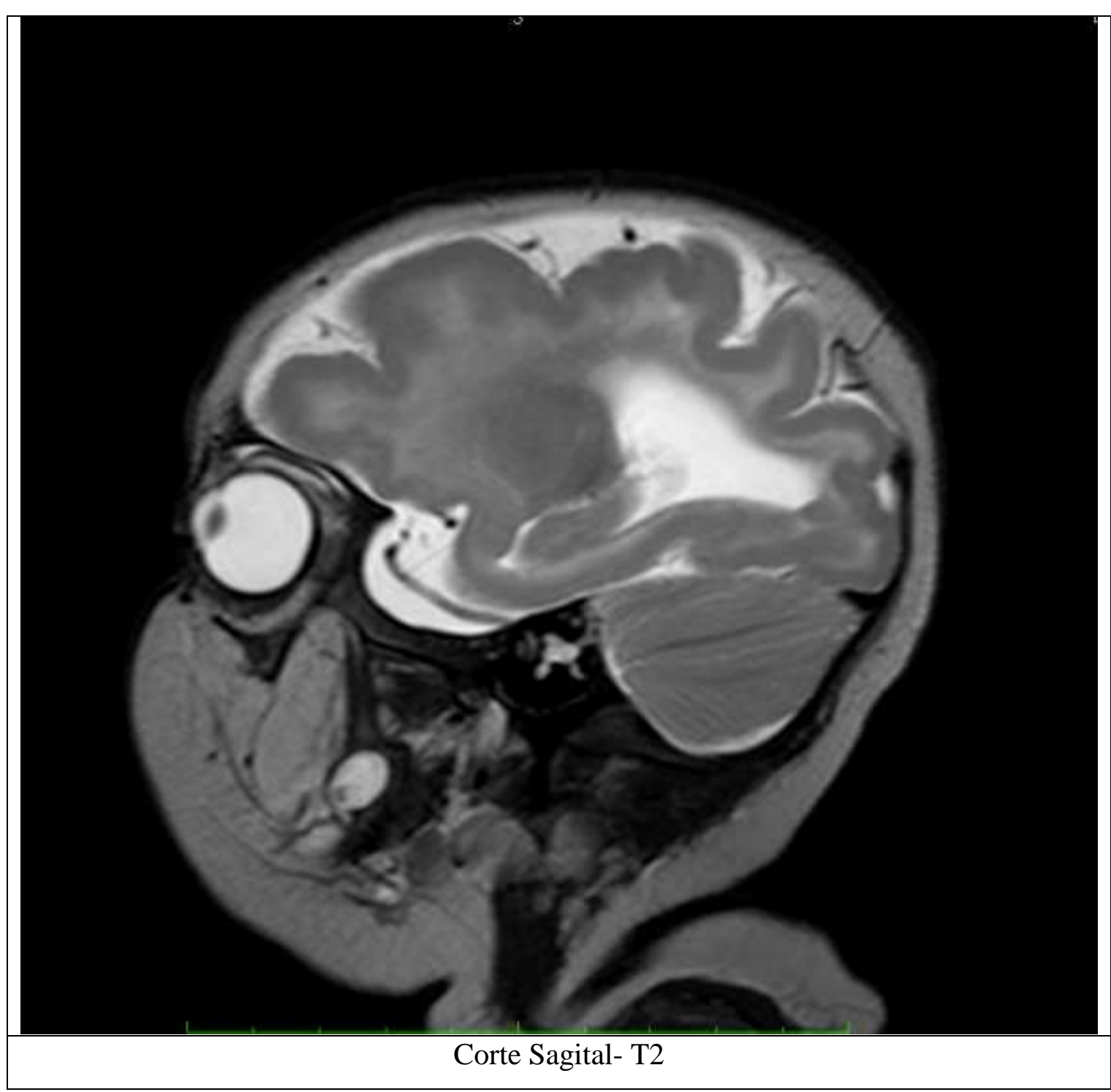




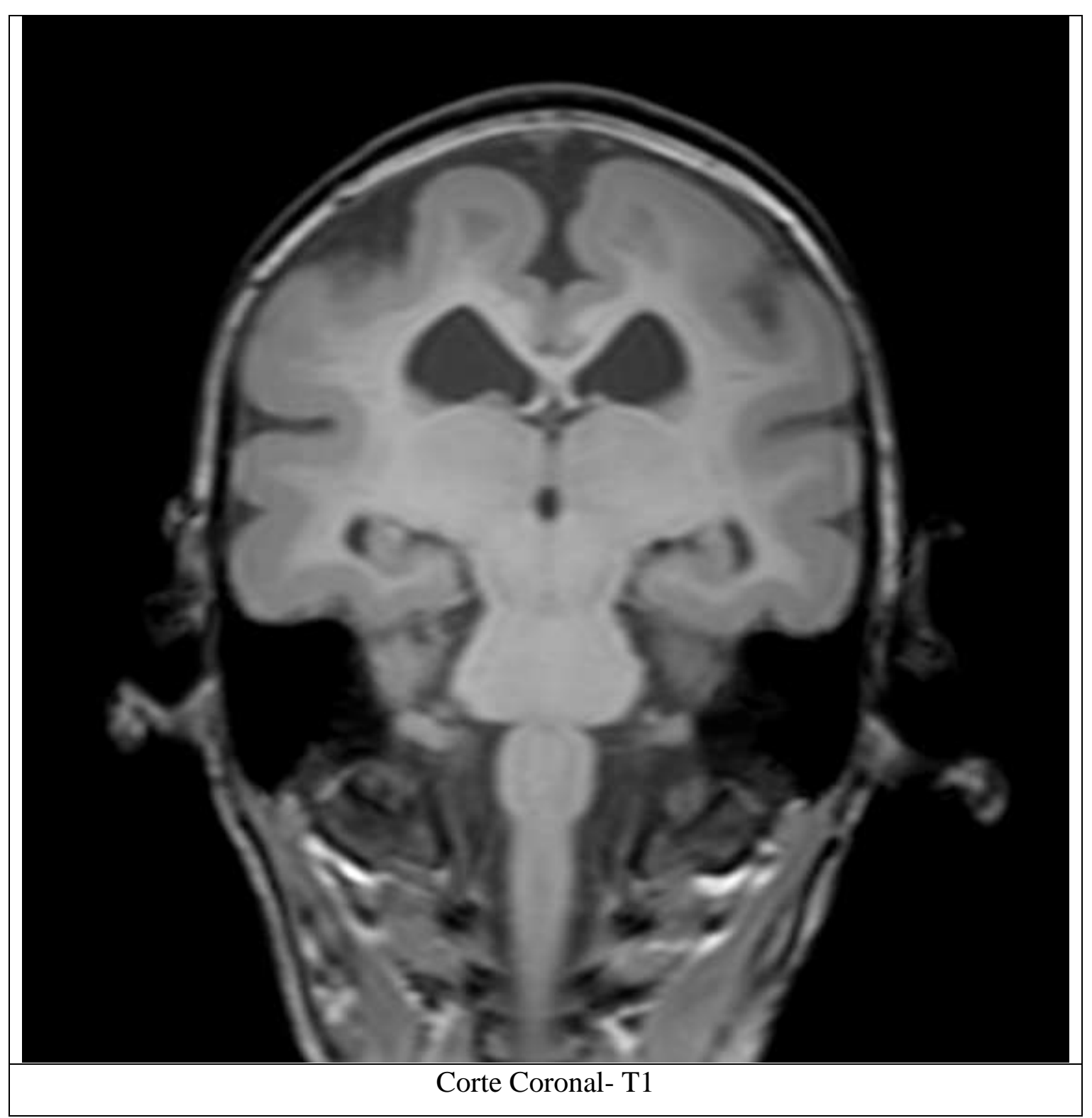


Imagens 2. Caso 2, sexo feminino. Presença de calcificações, ventriculomegalia e lisencefalia. Ribeirão Preto, 2018.

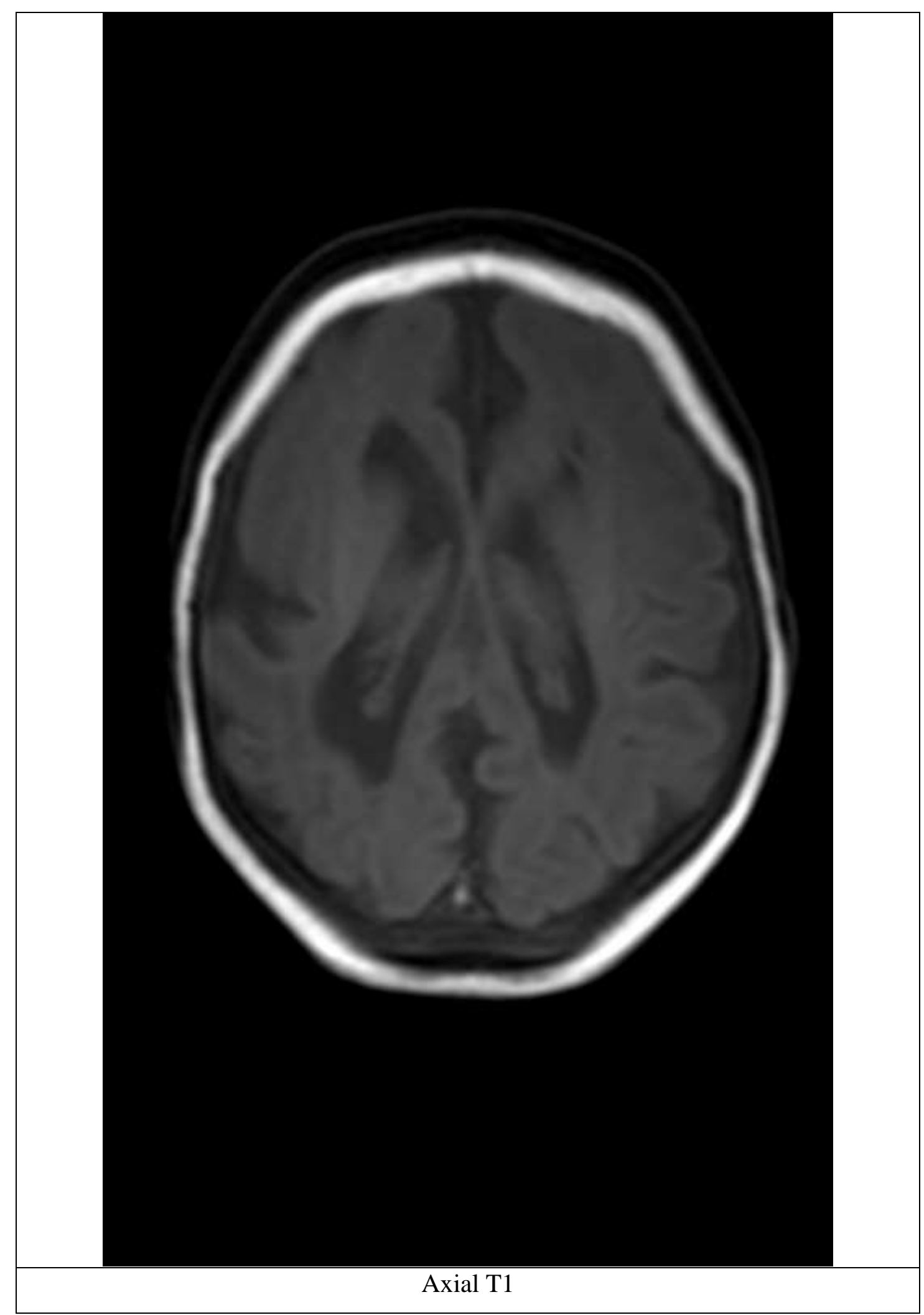




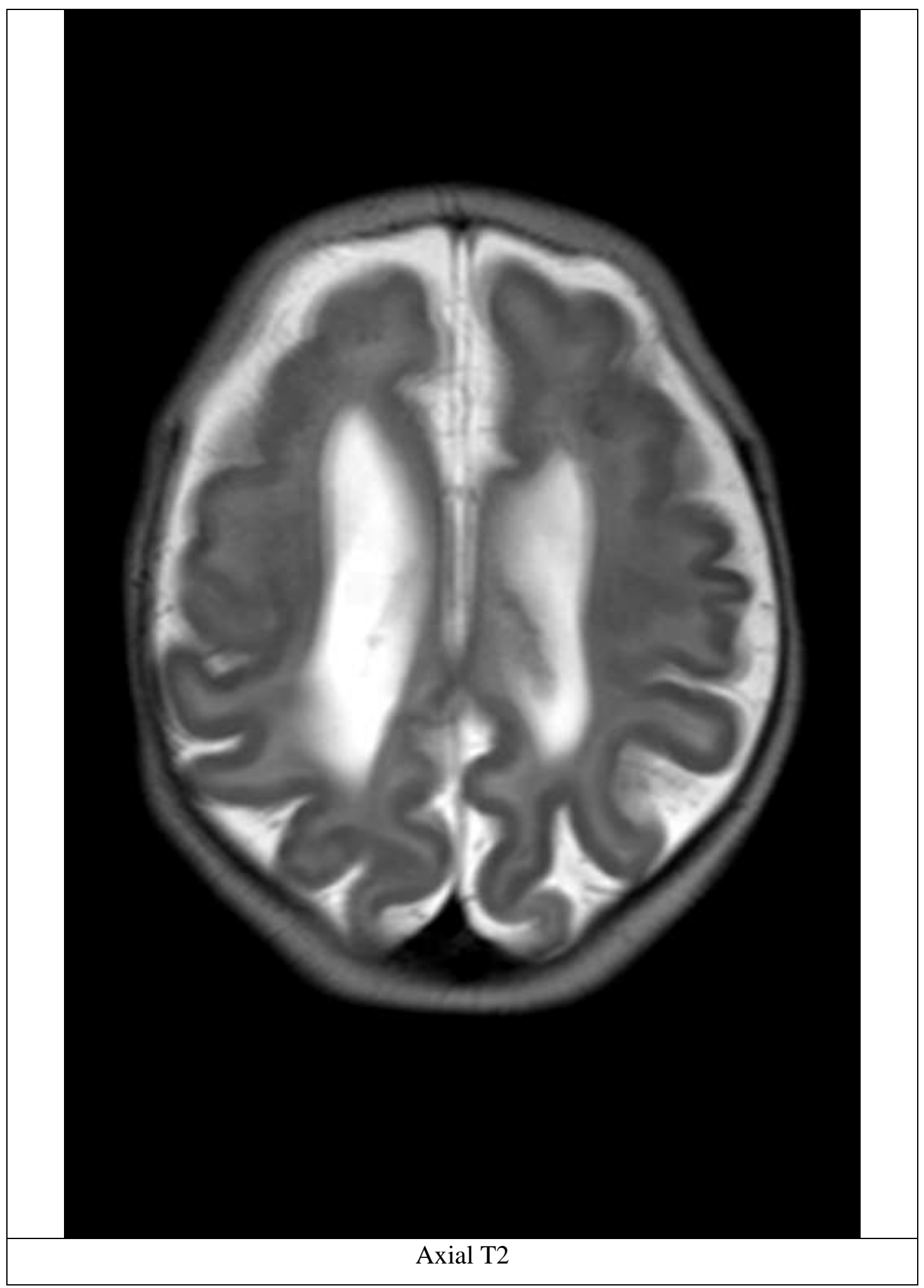




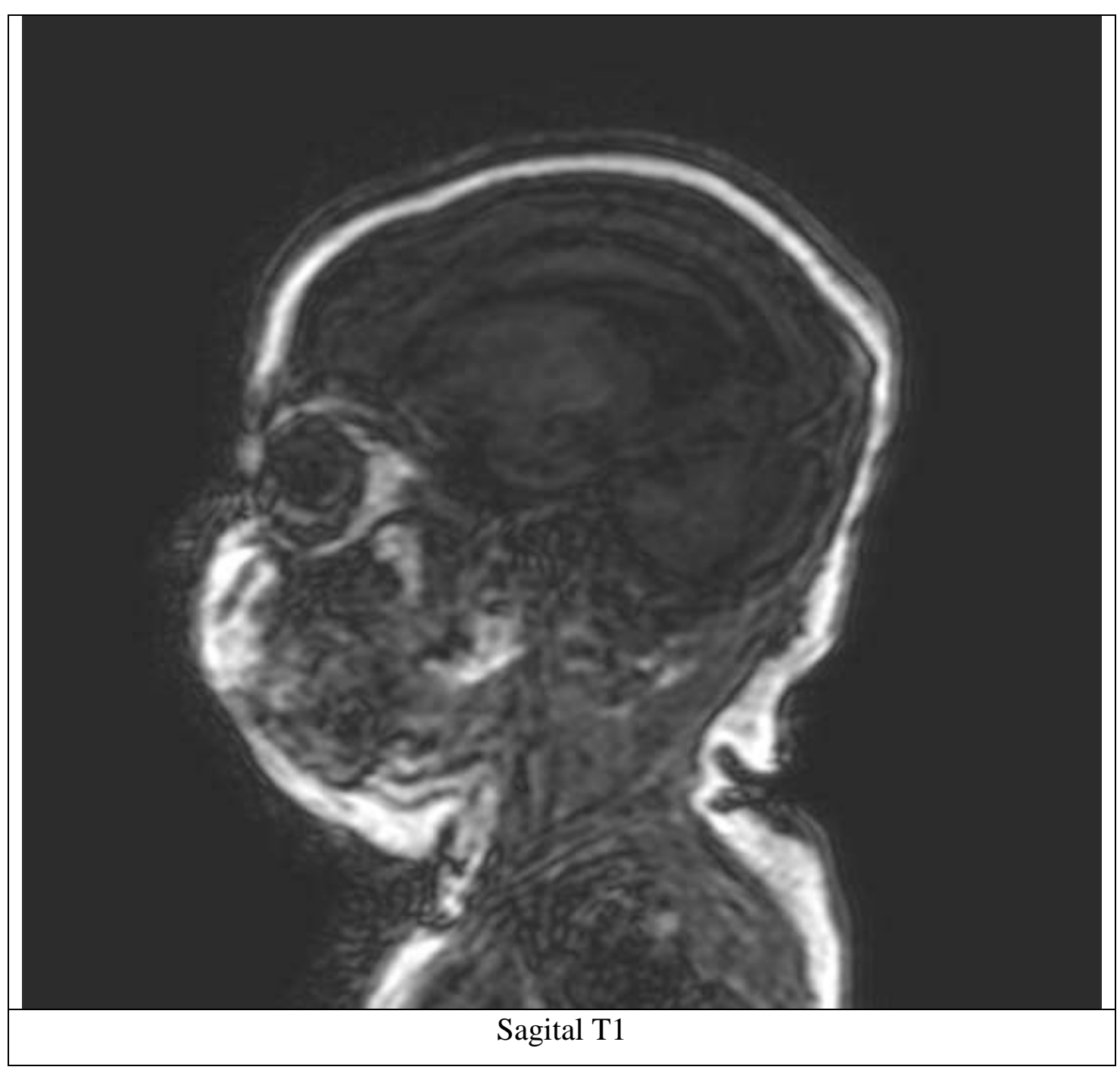




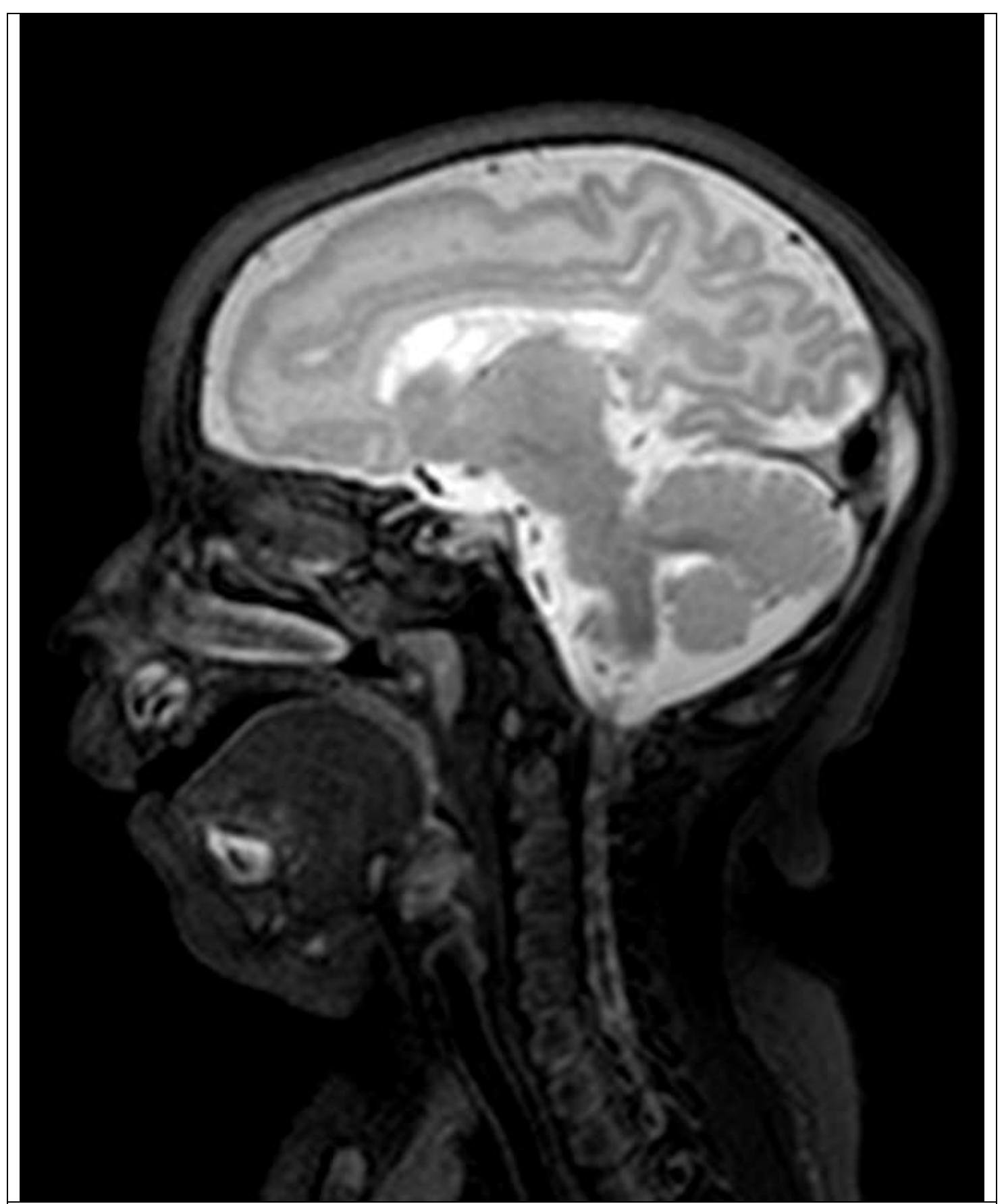

Sagital T2 


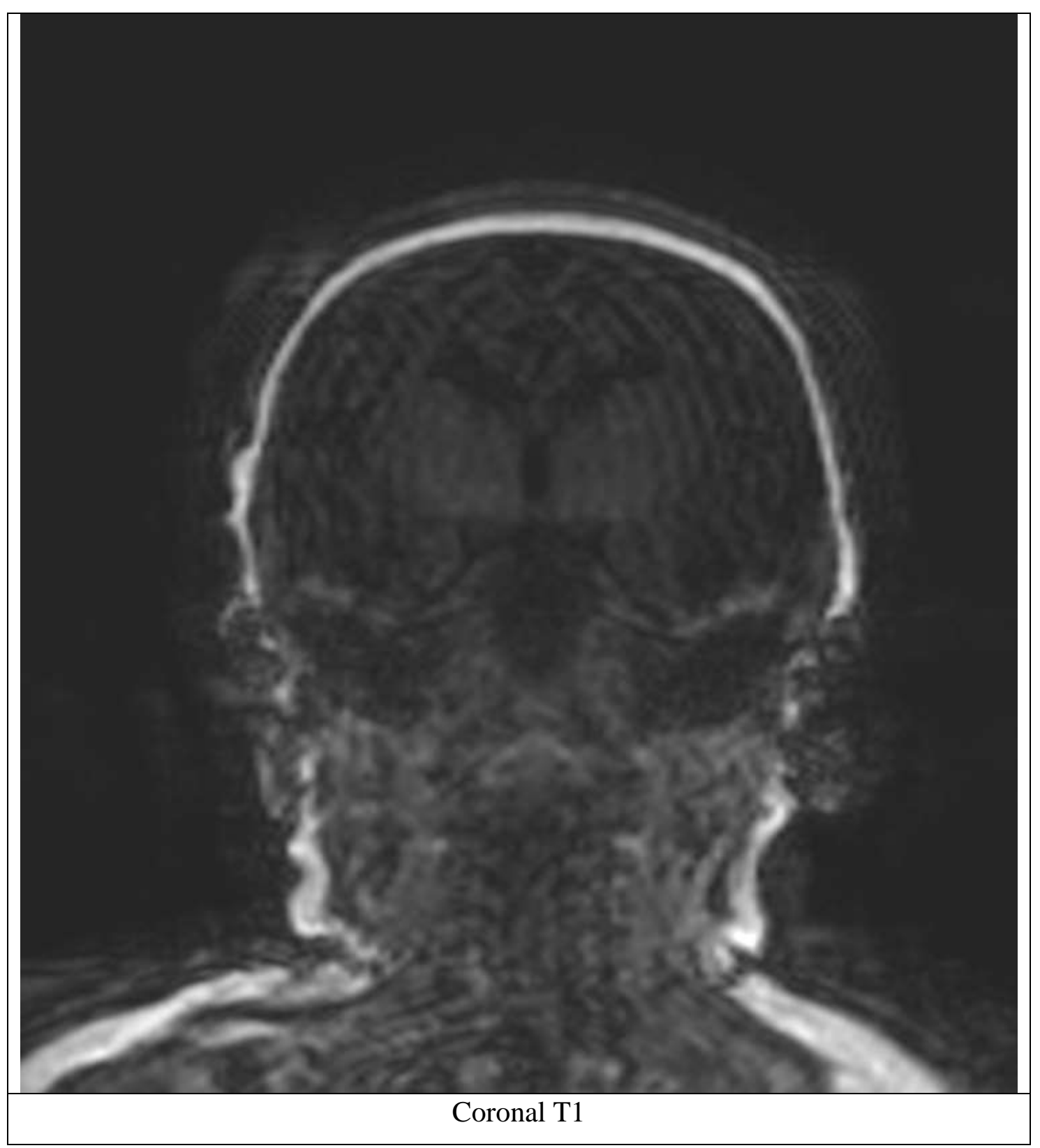




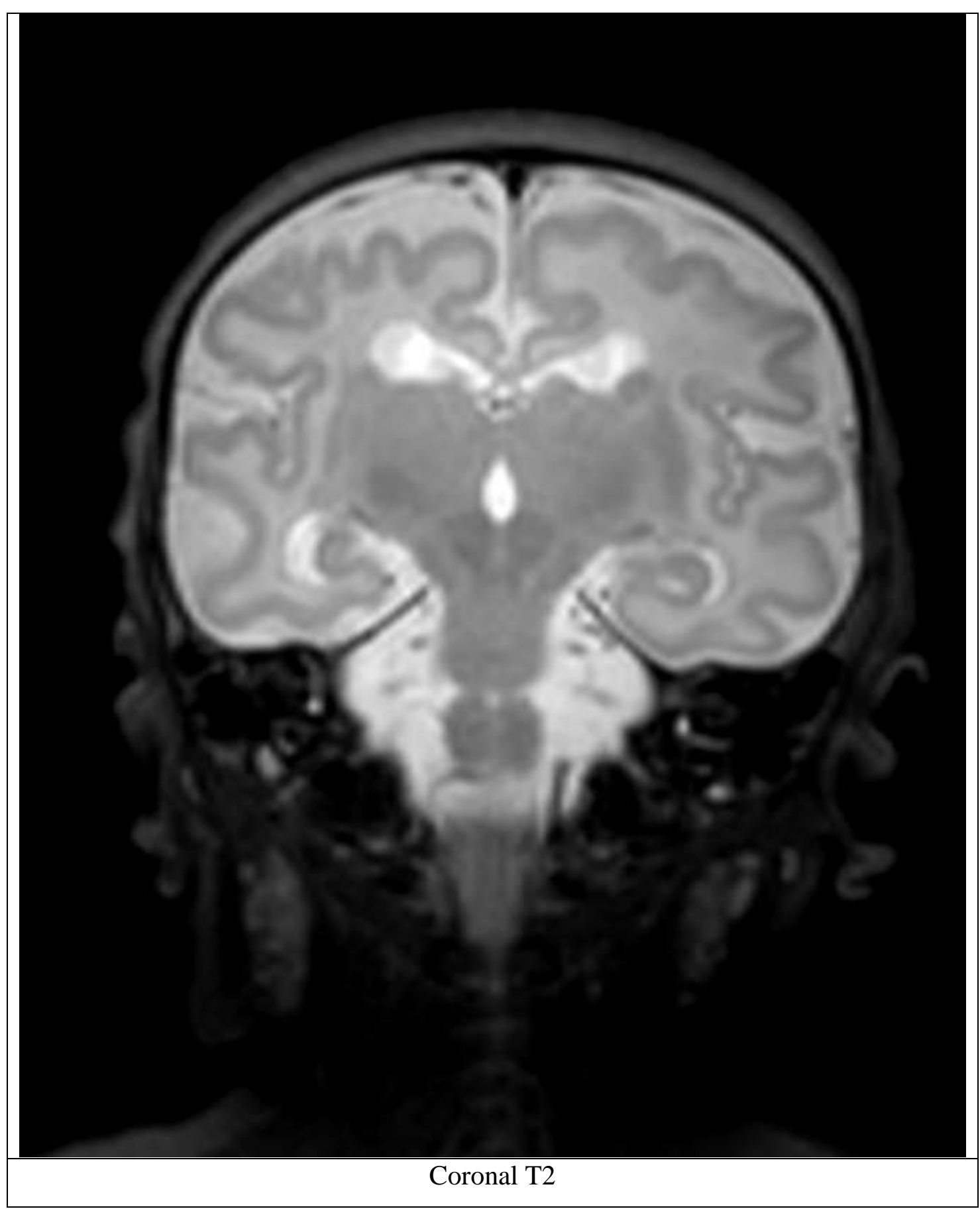


Imagens 3. Caso 3, sexo feminino. Presença de calcificação, ventriculomegalia, lisencefalia e paquigiria. Ribeirão Preto, 2018.

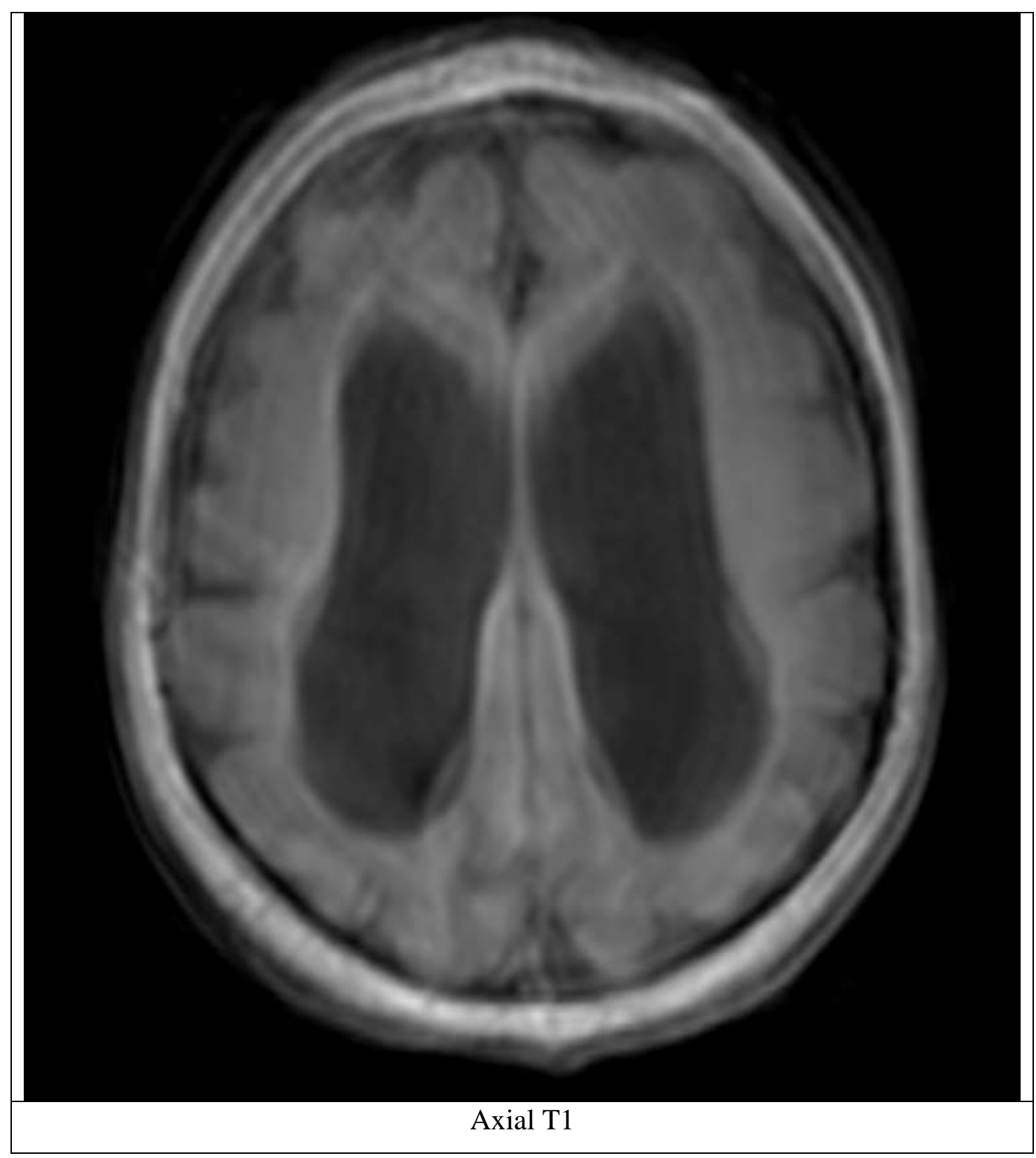




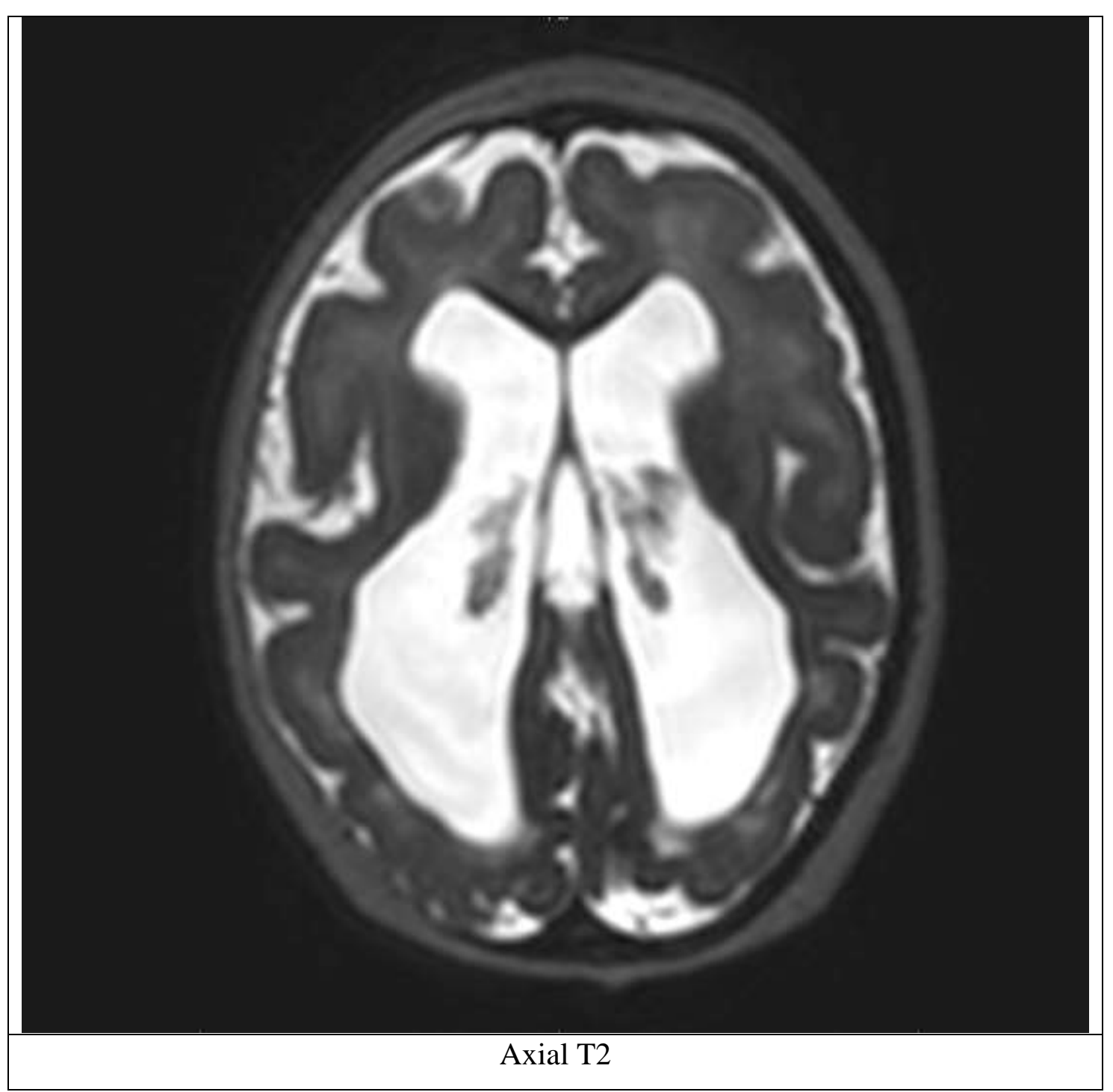




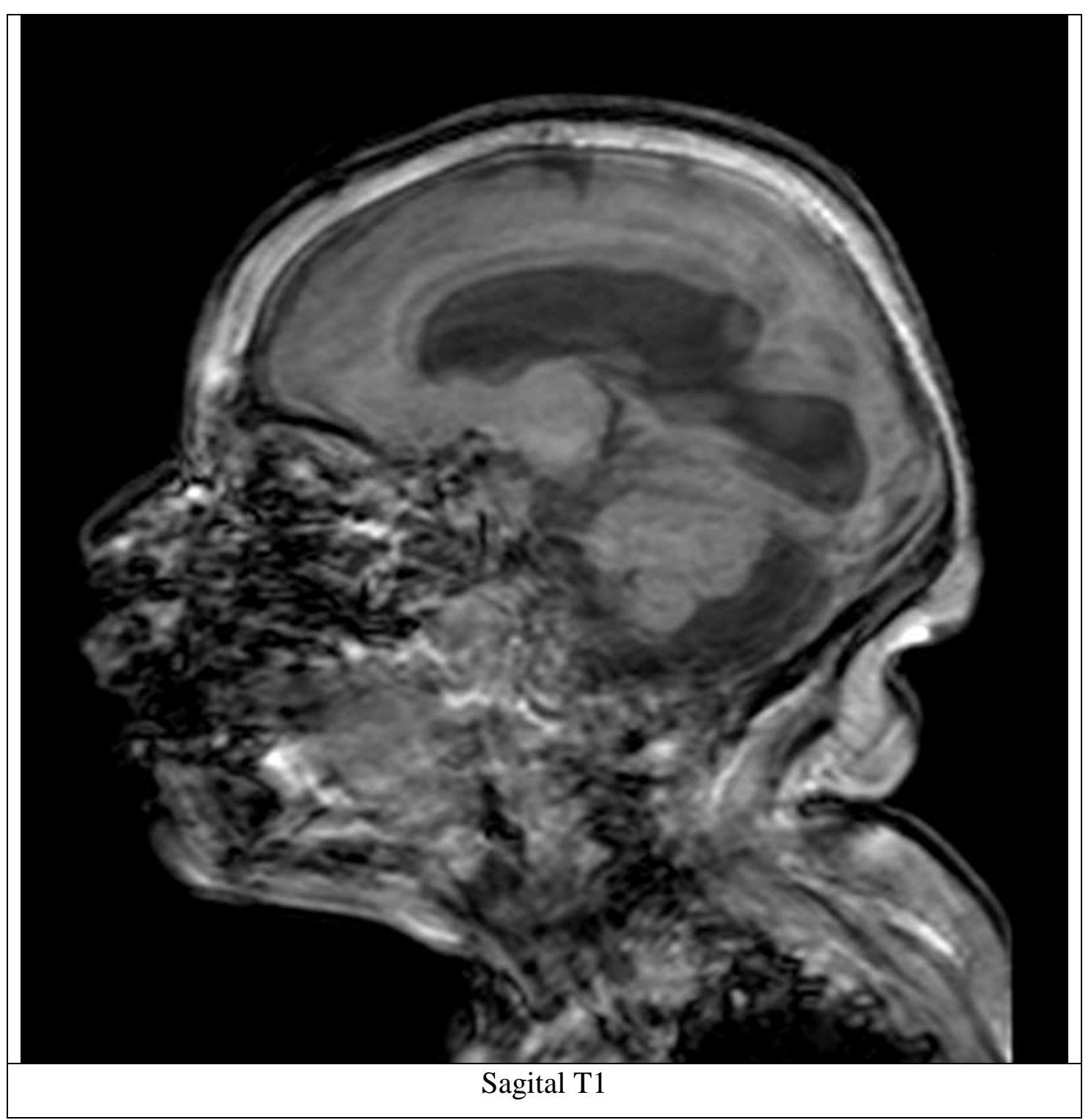




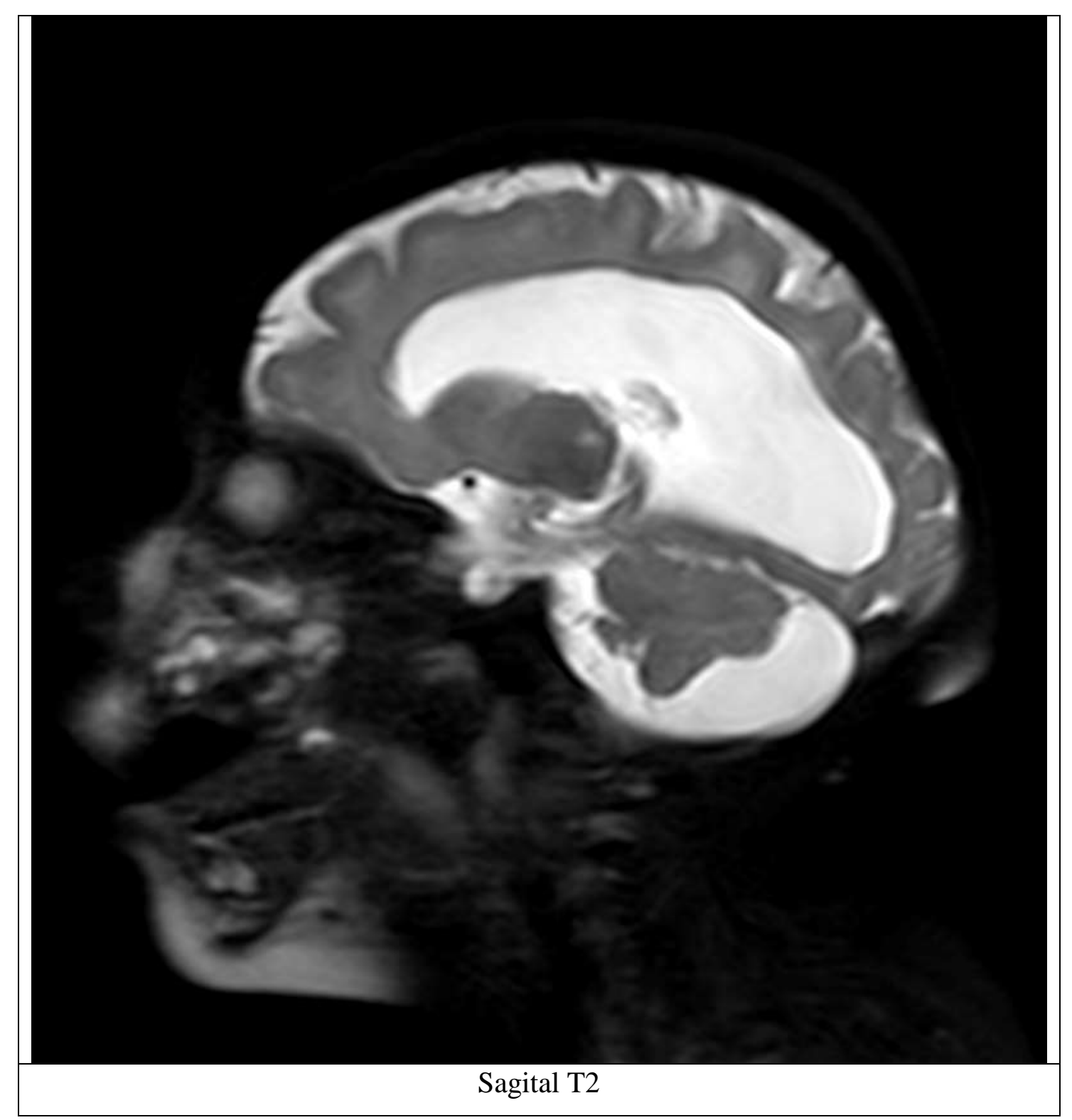




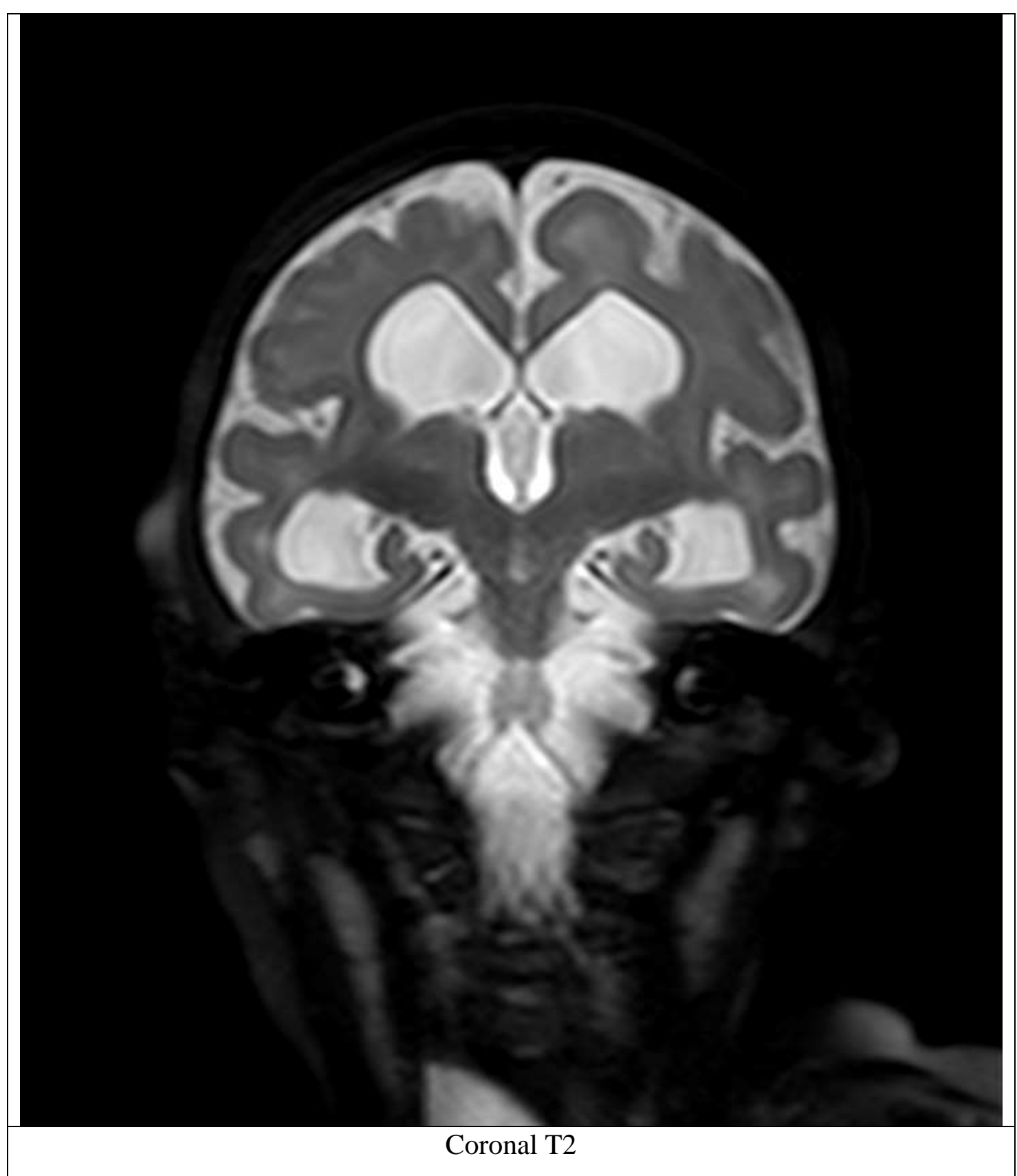




\section{DISCUSSÃO}

$\mathrm{O}$ valor do PC ao nascimento encontrado nas crianças com infecção pelo ZIKV é muito baixo, variando nessa amostra estudada de 26 a $31,5 \mathrm{~cm}$, com média de 28,3. No trabalho de Abreu, Novaes e Guimarães (2016), a média encontrada para um estudo transversal descritivo de 18 RNs igualmente infectadas verticalmente pelo ZIKV foi de 27,8, mantendo uma média próxima a encontrada nesse trabalho, considerada muita baixa.

A microcefalia congênita pode resultar em crescimento anormal durante a vida intrauterina, associada a síndromes genéticas, hipóxia neonatal, distúrbios metabólicos e exposição a pesticidas e infecções. Dentre essas, as principais infecções congênitas são usualmente conhecidas por TORSCH, que é a sigla usada para se referir à toxoplasmose, rubéola, sífilis, citomegalovírus e herpes simples (ASHWAL et al., 2009; DEVAKUMAR, 2018).

Na literatura não foi encontrada uma medida de PC em valores absolutos para uma margem comparativa. Alguns autores classificam o grau da microcefalia, sendo considerados graves aqueles cujo PC ao nascimento a termo é menor que três desvios padrões, o que corresponde a 30,4 cm para meninas e 30,6 para meninos (RODRIGUES; RODRIGUES, 2016).

Em nossa amostra, todas as crianças apresentaram microcefalia grave, com exceção de um menino, cujo PC foi $31,5 \mathrm{~cm}$. Na infecção congênita pelo citomegalovírus (CMV), causa conhecida de microcefalia congênita, $90 \%$ das crianças nascem assintomáticas e as outras $10 \%$ apresentam graus variados de comprometimento neurológico, com microcefalia de leve a grave, alterações neurológicas clinicamente imperceptíveis ao nascimento, por vezes com quadro de acometimento multissistêmico (ALFORD et al., 1990; YAMAMOTO; FIGUEIREDO; MUSSIPINHATA, 1999).

Em Ribeirão Preto, foram notificados 2326 casos suspeitos de infecção pelo ZIKV, desses 516 eram gestantes, cujos RNs foram acompanhados pelo projeto ZIG; destes 31 apresentaram microcefalia ao nascimento (MUSSI, et al., 2016).

Nesse contexto, para evitar os falsos positivos, o MS optou por reduzir o corte do valor do PC para as crianças com suspeita de infecção pelo ZIKV para $32 \mathrm{~cm}$ para meninos e $31,5 \mathrm{~cm}$ para meninas, além de propor a curva da Intergrowth para prematuros, a fim de reduzir os falsos positivos. O valor muito baixo do PC pode estar relacionado à MFSNC como lisencefalia e paquigiria, também presentes na infecção pelo CMV (TASSI et al., 2011). Por 
se tratarem de uma falha no período de migração celular, essas MF podem levar à microcefalia associada (BARKOVICH, 2010; BARKOVICH et al.,2001).

$\mathrm{Na}$ infecção congênita pela toxoplasmose se observa que o risco de infecção fetal aumenta com a IG, ao passo que a gravidade das sequelas diminui; enquanto na infecção congênita por ZIKV, o vírus tem tropismo pela placenta em qualquer IG, assim como tem pelo tecido cerebral nos fetos, o que poderia explicar a gravidade da microcefalia já ao nascimento - microcefalia congênita (LIMA et al., 2017).

Isso difere das crianças assintomáticas com infecção por CMV congênito, em que 2 a 7\% desenvolverão microcefalia - microcefalia adquirida - com graus variados de déficit no desenvolvimento nos primeiros dois anos de vida (STARR et al., 1970).

Os valores de PC masculino serem maiores que os femininos está de acordo com a população geral, conforme curvas de PC estabelecidas (SOCIEDADE BRASILEIRA DE PEDIATRIA, 2018)

Considerando a associação microcefalia congênita e MFSNC, era esperado que graus mais acentuados de microcefalia estivessem relacionados à maior gravidade dos quadros clínicos perinatal e neurológicos neonatais, bem como ao maior comprometimento de achados à neuroimagem. Contudo, a análise estatística do estudo não demonstrou esse resultado.

Não se observou relação entre o PC e o score HINE- N, alterações nos exames de imagem, dados perinatais e diagnóstico pré-natal de microcefalia ou infecção presuntiva ou comprovada pelo ZIKV. Isso provavelmente foi devido ao fato da amostra ser pequena $(\mathrm{n}=18)$ e relativamente homogênea com níveis de PC muito baixos e dentro de um intervalo pequeno de desvio padrão - para meninos tivemos a média de 29,1, mediana 29 e moda 30, enquanto para meninas, 27,7, 27 e 26 respectivamente.

Por outro lado, houve associação entre o valor do PC e a presença de crise neonatal. Nesse contexto, o valor muito baixo do PC nessa amostra poderia justificar a prevalência muito elevada de crises epilépticas neonatais - 77,8\% - visto que se esperaria uma associação forte com malformação do desenvolvimento cortical, conforme obtido nos nossos resultados (100\% da amostra).

Era esperado que outras séries de caso reproduzissem esse mesmo resultado. Todavia, em Recife, Alves e Souza (2016), observou-se uma prevalência de 37,7\% de crises epilépticas no estudo de 106 RNs com suspeita para infecção congênita por ZIKV.

Vale notar, que nesse estudo não houve separação da amostra por microcefalia, tendo sido descrito uma variação de PC de 22 a $34 \mathrm{~cm}$, o que poderia justificar a prevalência reduzida de crises epilépticas com relação a este trabalho (ALVES; SOUZA, 2016). 
Em nova coorte, publicada em agosto por Van der Linden e colaboradores (2018), dos 141 RNs avaliados, 67\% evoluíram com crises epilépticas, mas não há descrição de quantas ocorreram no período neonatal. Dos pacientes avaliados neste trabalho, $14(77,78 \%)$ apresentaram crises neonatais, sendo que desses, 8 (57,14\%) obtiveram controle das mesmas no período neonatal.

O não controle das crises pode ter implicações negativas no prognóstico neurológico dessas crianças, uma vez que as crises prolongadas podem causar lesões no SNC por meio da excitotoxicidade - liberação excessiva de aminoácidos excitatórios como glutamato, aspartato, quisquilato e ácido caínico - com consequentes alterações iônicas - acúmulo de cálcio intracelular (JOHNSTON; MC DONALD, 1993).

No entanto, sugere-se que as crises neonatais por si só não determinam a ocorrência dessas alterações metabólicas a não ser que haja hipoxemia ou lactoacidose importantes associadas (COWAN et al., 1987). Também não há evidências de que crises breves causem lesão cerebral em séries com animais imaturos (ALBALA; MOSHÉ; OKAD, 1984; HOLMES, 1991).

Como a maioria das crianças não realizou poligrafia neonatal, os achados eletroencefalográficos não foram incluídos nesse trabalho.

Além da variação do PC, os pacientes desse estudo mostraram que a presença de ventriculomegalia e calcificação na RM tem associação com a presença de crises epilépticas, o que pode estar relacionado à provável foco epileptogênico associado à malformação nesses casos.

A associação de crises com MDC é bem estabelecida na literatura médica (Barkovich). Não foi destacada essa associação nesta série devido à presença de MDC na totalidade da amostra. Para melhor entendimento de cada caso, faz- se necessária a complementação com estudo eletroencefalográfico e seguimento clínico dessas crianças, que é proposta de continuidade para novo trabalho.

Em contrapartida, a presença de crises neonatais não foi relacionada à IG ou APGAR dos RNs, provavelmente devido à homogeneidade da amostra. Todos os RN, à exceção de 1 , foram termos, e todos os valores encontrados para APGAR foram acima de 7. Também não houve associação com o PN, local de nascimento, tipo de parto, tempo de internação e score do HINE-N.

Como preconizado pelo MS, houve uma busca ativa do diagnóstico pré-natal da infecção pelo ZIKV. Como as infecções pelo ZIKV ocorreram primeiro no Nordeste em maio de 2015, houve tempo para a cidade de Ribeirão Preto, através do HCFMRP-USP, se preparar 
para receber os possíveis casos. Havia latente uma preocupação geral com a proliferação do vetor Aedes aegypti devido às condições climáticas locais e já era vigente a epidemia do vírus da dengue na cidade (MUSSI et al., 2016).

Nessa ocasião, as equipes de Pediatria, Ginecologia e Obstetrícia e Infecções Congênitas, representadas respectivamente pelos professores Marisa Márcia Mussi, Geraldo Duarte e Aparecida Yulie Yamamoto, uniram esforços para elaborar o plano de assistência às gestantes com suspeita de infecção pelo ZIKV, que foram acompanhadas no projeto ZIG do Hospital das Clínicas de Ribeirão Preto, segundo as normas do MS.

A indicação da via de parto, como foi proposta pelo MS, foi obstétrica, uma vez que a maioria das crianças nasceu de parto normal, mesmo as que tinham diagnósticos pré- natal de infecção pelo ZIKV (Protocolo de atenção à saúde). A proporção encontrada foi de $72.22 \%$ de parto normal, enquanto na população geral do Brasil a proporção média é menor que isso, de 58,1\% parto normal no Sistema Único de Saúde (SUS) em 2017 (BRASIL, 2016).

As crianças que nasceram em Ribeirão Preto foram aquelas que realizaram o pré-natal completo, tendo assim o diagnóstico de infecção pelo ZIKV mais precoce e a possibilidade de programar o parto em hospital de referência. Isso ocorreu graças ao preparo da equipe de saúde para diagnosticar essas gestantes e crianças e segui-las em um hospital terciário que havia se organizado para possível epidemia. Em nossa amostra, 72,2\% das crianças tiveram diagnóstico no pré- natal de microcefalia, enquanto $66,7 \%$ de provável infecção congênita por ZIKV.

O diagnóstico intraútero teve relação com as mulheres que realizaram o pré- natal completo durante a gestação, ressaltando a política de assistência à gestante preconizada pelo MS. Não necessariamente os casos com microcefalia diagnosticada intraútero foram relacionados aos menores valores de PC ao nascimento segundo dados estatísticos da análise. Mais uma vez isso pode ser explicado pela homogeneidade de valores de PC, considerados muito próximos nos 18 casos estudados.

Dentre as condições clínicas de nascimento destacam-se o PN e a IG. Na avaliação pediátrica, os valores de PN são classificados em pequeno para idade gestacional (PIG) quando o peso estava abaixo do p10, adequado para idade gestacional (AIG), peso entre o p10-90, e grande para idade gestacional (GIG), peso acima do p90 (BATTAGLIA; LUBCHENCO, 1967).

Das crianças desse estudo, 7 (38,89\%) foram classificadas como PIG e o restante como AIG. Há ainda a classificação da OMS, citada pelo tratado de pediatria do Nelson, 2009, que independe da idade gestacional, sendo extremo baixo peso ao nascimento (EBPN) 
as crianças nascidas com peso abaixo de 1000 gramas, muito abaixo peso ao nascimento (MBPN), abaixo de 1500 gramas e baixo peso ao nascimento (BPN) abaixo de 2000 gramas.

No presente estudo apenas uma criança foi classificada como MBP, tratando-se de uma criança prematura de 32 semanas e PN de 1228 gramas. Esta foi a única criança prematura extrema; as demais foram nascidas a termo. No estudo realizado em Recife por Alves e Souza (2016), dos 18 RNs, a IG média foi de 37 (+/- 2,9) semanas, PC 27,8 (2,2) centímetros, PN 2079,8 (560,9) gramas.

A determinação do PN da criança sofre influência de fatores relativos ao feto, à genitora e ao ambiente (BARBAS et AL, 2009). Em ordem decrescente de importância temos hemorragias durante a gestação, elevação da pressão arterial na gestação, pequeno número de consultas de pré-natal, antecedente de parto prematuro, cardiopatia materna, amniorrexe prematura, intervalo interpartal menor ou igual há 12 meses, antecedente de hipertensão arterial crônica, baixo peso materno pré- gestacional, hábito de fumar além do $4^{\circ}$ mês de gestação, intervalo interpartal maior ou igual a 37 meses, baixa escolaridade, doenças infecciosas na gestação, início tardio do pré-natal (após o $3^{\circ}$ mês), antecedente de cesárea e idade materna (BETTIOL et al., 2010).

Apesar dessa variação de peso e de IG observada no nosso estudo, o APGAR de todas as crianças foi maior que sete o que mostra que essas nasceram bem, com os reflexos primitivos de sobrevivência adequados - infracorticais - sem inibição pelo córtex, como esperado para idade neonatal. Isso é devido à infecção pelo ZIKV ser uma doença primariamente neurológica, com pouco comprometimento sistêmico, e de curso crônico, no que se diferencia da anóxia neonatal e de seus mecanismos hemodinâmicos de ajuste cerebral, incorrendo em complicações agudas ao nascimento.

A incidência de anóxia ou asfixia perinatal varia na literatura de 3 a 6 por 1000 nascidos vivos, sendo a causa mais frequente de encefalopatia hipóxico isquêmica (EHI) no período neonatal, principalmente nos RN pré-termos, cuja resposta tecidual a agressões é imatura, levando a maior predisposição para dano cerebral. Usualmente os primeiros sintomas são letargia, apneia, crises epilépticas, apatia e hipotonia, podendo culminar em disfunção do tronco encefálico nas primeiras 72 horas de vida - morte encefálica (RODRIGUES; RODRIGUES, 2016).

Para Sarnat e Sarnat, (1976), a EHI pode ser classifica em 3 estágios - branda, moderada e grave - de acordo com o acometimento nos seguintes quesitos: nível de consciência, controle neuromuscular, tônus muscular, postura, reflexos tendinosos, mioclonia, convulsões, reflexos complexos (sucção, Moro, oculovestibular, tônico do pescoço), funções 
autonômicas (pupilas, respiração, ritmo cardíaco, secreções de vias aéreas, motilidade gastrointestinal), padrão eletroencefalográfico, duração dos sintomas e seguimento.

Vale também pontuar, que estudos tem evidenciado que o APGAR é falho para demonstrar lesão neurológica quando tomado como fator avaliador único, porém quando este se encontra abaixo de sete no $5^{\circ}$ minuto (diferente de nossa amostra), mesmo na ausência de alterações laboratoriais, é necessária uma atenção especial ao RN (PROCIANOY et al., 2001; CUNHA ET AL, 2004).

O tempo de internação ao nascimento variou entre 3 e 59 dias, média de 12,5. Os motivos principais de internação foram controle de crises neonatais, motivos pediátricos, mas principalmente questões sociais, no intuito de facilitar a investigação diagnóstica, uma vez que o baixo padrão econômico dessa população dificultava o acesso à saúde e aos retornos necessários. Essa medida atendeu às solicitações do MS, adaptadas para a realidade local. (BRASIL, 2016).

Houve significância entre os achados encontrados na RM e no USTF, o que coloca este como uma boa opção de exame de imagem completar ao nascimento, uma vez que tem um baixo custo e é de mais fácil acesso que a RM, como sugerido por Gupta et al. (2016).

Isso reitera a importância do uso do USTF como método de escolha para a detecção e acompanhamento das lesões neurológicas em RNs de risco, uma vez que pode ser realizado à beira do leito na fase aguda da doença ou em RNs hígidos, tem alta sensibilidade, não utiliza radiação, é não invasivo e de fácil e rápida execução por médicos capacitados (KASKE; RUMACK; HARLOW, 1998).

Apesar da gravidade da microcefalia em nossa amostra, o uso do USTF como método diagnóstico complementar só foi possível devido à permeabilidade das fontanelas anteriores, o que pode não ocorrer em casos de microcefalia congênita por outras etiologias.

A pontuação dos HINE- $\mathrm{N}$ nesse trabalho teve média de 17,2 para meninas e 18,06 para meninos com mediana 17 e 18,25, respectivamente, sendo que $100 \%$ das crianças apresentou score abaixo da normalidade. A comparação desses achados com os dados disponíveis na literatura é difícil pela escassez de trabalhos sobre o assunto, principalmente quando em relação a infecções congênitas- nenhum trabalho foi encontrado. $O$ protocolo HINE- N foi aplicado no Vietña com RNs a termo, sendo que $95 \%$ das crianças apresentaram pontuação total dentro do esperado (DUBOWITZ; MERCURI; DUBOWITZ, 1998).

Os pesquisadores Mercuri e Dubowitz (1999) aplicaram o exame em 224 RN termo de baixo risco, encontrando pontuação média de 32,87, com variação de 25 a 34 pontos, bem 
superiores às médias obtidas no nosso trabalho, indicando a gravidade da infecção congênita pelo ZIKV em termos neurológicos.

No estudo de Nascimento e colaboradores (2011), foram avaliados 30 RNs termo de baixo risco na maternidade do Hospital Estadual Mário Covas e $80 \%$ atingiu pontuação esperada para normalidade. Em 1983, uma amostra de 60 RNs a termo sem evidências de intercorrências clínicas alcançou 87\% do score esperados (FORSLOUND; 1983).

A maioria dos trabalhos que utilizaram o protocolo HINE- $\mathrm{N}$ foi realizada em coortes de RNs saudáveis, evidenciando os padrões de normalidade esperados para cada domínio desse exame neurológico.

Por sua vez, Golin e colaboradores (2009), realizaram uma coorte de RNs prematuros, os quais foram avaliados com idade correspondente de termo, mas apenas $10 \%$ atingiram os parâmetros de normalidade esperados quando comparados ao grupo controle, formado por RNs nascidos a termo.

Não há séries de RNs com infecções congênitas ou anóxia neonatal avaliadas por meio da aplicação do protocolo HINE- N. Com isso, pode-se perceber que há escassez de dados comparativos desse instrumento para avaliar populações de risco para doenças neurológicas ou com doenças neurológicas pré-estabelecidas.

Apesar de ser possível pressupor que este protocolo estaria alterado frente a essas condições, seria difícil estimar a gradação dessa alteração por carência de referências na literatura. A opção do uso do HINE- N neste trabalho visa retomar a padronização do exame neurológico para essa população, avaliando os domínios de forma individual e, ulteriormente, comparando resultados com o HINE evolutivo para fins prognósticos.

Com base no estudo de Dubowitz e Mercuri (1998), temos o score esperado para cada item e domínio do exame neurológico de HINE- N. Comparando os valores propostos no trabalho anterior com os dados encontrados em nosso trabalho, temos a seguinte média de pontuação e percentual com relação ao esperado para cada domínio:

- postura e tônus: 6,3 para feminino e 6 para masculino, ou seja, 63\% do esperado para masculino e $60 \%$ para feminino;

- padrões de tônus: 4 (80\%) e 4,25 (85\%);

- reflexos: $0,8(13,33 \%)$ e $0,75(12,5 \%)$;

- movimentos: $1,7(56,67 \%)$ e $1,44(48 \%)$;

- padrões e sinais anormais: 1,2 (40\%) e 1,63 (54,33\%);

- comportamento: $3,2(45,7 \%)$ e $4(57,14 \%)$; 
Com base nesses dados, podemos perceber que o grau do acometimento dos RNs com infecção congênita pelo ZIKV por domínios em ordem decrescente é: reflexos, padrões e sinais anormais, comportamento, movimentos, postura e tônus e, por fim, padrões de tônus. Conforme evidenciado no trabalho de Botelho e colaboradores (2016), a alteração dos reflexos, da motricidade espontânea e do tônus muscular - caracterizada por hiperreflexia, movimentação anormal e hipertonia dos quatro membros com hipotonia de eixo - também se mostra bem prevalente em nossa amostra, evidenciando a gravidade da lesão pré- natal dessas crianças, que leva a sinais precoces de paralisia cerebral quando comparadas a crianças que sofreram lesões cerebrais perinatais, como a asfixia perinatal.

Diante desta distribuição fica clara a importância da análise observacional dos movimentos e se faz necessária uma análise mais meticulosa dessas crianças, como a proposta por Pretchl, que orienta a avaliação dos movimentos generalizados (MG) espontâneos do RN, que envolvem o corpo como um todo, estando presentes tanto no estado de vigília como sono e cuja qualidade e intensidade são sinais da integridade funcional do SNC do RN.

Por outro lado, os vários padrões de anormalidade são indicadores de evolução neurológica insatisfatória, o que torna esta avaliação uma ferramenta importante para diagnóstico de lesão cerebral perinatal (GARCIA; CHERPELLI; LEONE, 2004).

No entanto, a ausência dos dados neurológicos evolutivos nesta análise torna limitada a interpretação dos subdomínios afetados em nossa amostra, o que pode ter ou não valor prognóstico em uma análise longitudinal, o que é a intenção da equipe de pesquisa.

O protocolo HINE- N resumido proposto por Mercuri et al. (2005), não foi aplicado em nossa população durante o estudo como método de triagem, mas durante a avaliação dos dados pode-se observar que essas crianças apresentavam alteração apenas nos seguintes itens propostos como sinais de alarme: movimentos espontâneos- qualitativo, tremor, alerta e orientação visual.

Os demais sinais de alarme - postura, tração de braço e perna, controle da cabeça extensor e flexor, resposta à tração e suspensão ventral, reflexo de Moro e orientação auditiva- não apresentaram alteração significativa. Na amostra avaliada, pode-se observar um padrão de tendência à normalidade na maior parte do exame, incluindo itens considerados como sinais de alarme.

Os itens com tendência à normalidade são recuo de braço, tração de braço e perna, ângulo poplíteo, tônus flexor 1, tônus extensor da perna, tônus extensor cervical, aumento do tônus extensor, reflexo de sucção, preensão palmar e plantar, colocação plantar, reflexo de 
Moro, posturas anormais das mãos e dedos dos pés, aparência dos olhos, orientação auditiva e consolabilidade.

No entanto, com base nos mesmos pacientes, é possível observar certo padrão de acometimento, de forma a ser relevante propor como sinais de alarme para essa população a presença de alterações nos seguintes itens: reflexos tendíneos, movimentos espontâneosqualitativo, tremor, susto, alerta, irritabilidade, tônus flexor 2, orientação visual e choro.

Dessa forma, podem-se propor esses sinais listados como um modelo a ser aplicado para RN com diagnóstico ou suspeita de infecção congênita por ZIKV ou mesmo para infecções congênitas em geral ou outros insultos intraútero subagudos ou crônicos. Esse padrão de acometimento faz alusão novamente à proposta de avaliação dos MG de Pretchl.

A diferenciação do padrão com relação aos primeiros estudos pode ser decorrente das diferentes populações estudadas, pois as propostas iniciais eram para aplicação em RNs termos e prematuros, que usualmente são acometidos por lesões neurológicas agudas, como anóxia neonatal e hemorragias periventriculares.

No caso das crianças com infecções congênitas, têm-se pacientes vítimas de lesões neurológicas crônicas, o que pode tornar ainda mais sutil as alterações no exame neurológico padrão.

$\mathrm{Na}$ análise estatística, o HINE- $\mathrm{N}$ não demostrou relação com nenhuma variável avaliada provavelmente pelos índices homogeneamente rebaixados do score total, conforme descrito.

Esses pacientes foram seguidos no serviço e foi aplicado o HINE evolutivo até 18 meses. Os resultados obtidos com esse trabalho - o score total, os domínios e subdomínios do HINE- N - têm ainda finalidade prognóstica através da análise de fatores de risco implicados no desenvolvimento neurológico dessas crianças. Em outras palavras, esses resultados servirão de base para o estudo neurológico evolutivo em lactentes a ser realizado por essa equipe de pesquisa. 


\section{CONCLUSÃO}

O presente estudo avaliou 18 RNs com microcefalia secundária à infecção congênita pelo ZIKV na cidade de Ribeirão Preto e sua DRS no momento de sua grande epidemia nessa região.

Quanto as condições de nascimento, apenas uma era prematura, todas apresentaram APGAR maior que 7 e o PN tendeu à normalidade.

Quase a totalidade das gestantes da amostra realizou pré-natal de forma completa, uma parcela de $72,2 \%$ da população teve diagnóstico pré-natal de microcefalia e $66,7 \%$ de infecção por ZIKV durante a gestação.

Diferentemente de outros estudos prévios sobre o tema, a população foi gravemente acometida por crises epilépticas neonatais, um dos motivos pelos quais o tempo de internação foi aumentado.

A realização de exames de neuroimagem foi possível em toda amostra, sendo que $72,2 \%$ das crianças foram submetidas ao USTF e $100 \%$ foram submetidas à RM, com resultados fortemente associados entre si, reiterando a utilidade do USTF como importante método de triagem a ser realizado à beira leito nos RNs de risco. Todos os pacientes apresentaram MDC. As alterações encontradas à imagem foram calcificações, ventriculomegalia e malformação cortical - lisencefalia isolada ou associada, polimicrogiria e outras, como a paquigiria.

À avaliação por meio do protoloco HINE- N, obtivemos score geral muito baixo, provavelmente secundário ao grau de acometimento neurológico da população estudada, com leve oscilação entre os gêneros, o que pode ser explicado pela amostragem pequena.

$\mathrm{Na}$ análise estatística não foi encontrada relação entre o score HINE- $\mathrm{N}$ e as variáveis clínicas propostas pelo estudo provavelmente por se tratar de um estudo transversal com amostra muito pequena e homogênea. Deste fato podemos concluir a importância de ser realizado um seguimento prospectivo dessa população, como pretendem os pesquisadores deste trabalho.

Foi demonstrada relação entre o valor do PC e a ocorrência de crises neonatais, a realização de pré- natal completo e a cidade de residência, local de nascimento, diagnóstico pré- natal de microcefalia e de infecção por ZIKV, bem como a escolha da via de parto. Também houve associação entre a ocorrência de crise epiléptica e a presença de ventriculomegalia e/ou calcificações na RM. 
Pôde ser observado que, apesar da infecção congênita pelo ZIKV ser um tema relevante em nosso país, ainda há escassez de estudos para comparar os dados encontrados tanto com populações acometidas pela mesma patologia quanto por outras infecções congênitas ou outras causas de malformações que tenham utilizado o mesmo instrumento proposto nessa série.

Por fim podemos concluir que este estudo aponta para necessidade de acompanhamento neurológico dessas crianças a fim de ser possível avaliar o padrão evolutivo dessas, com ênfase nos domínios propostos pelo HINE, bem como os fatores clínicodemográficos que interferem no prognóstico desses pacientes, como pretendem os pesquisadores deste trabalho. 


\section{REFERÊNCIAS}

ABREU, T. T.; NOVAIS, M. C. M.; GUIMARÃES, I. C. B. Crianças com microcefalia associada a infecção congênita pelo vírus Zika: características clinicas e epidemiológicas num hospital terciário. Revista de Ciências Médicas e Biológicas, v. 15, n. 3, p. 426-433, 2016.

ALBALA, B. J.; MOSHÉ, S. L.; OKADA, R. Kainic-acid-induced seizures: a developmental study. Developmental Brain Research, v. 13, n. 1, p. 139-148, 1984.

ALFORD, C. A. et al. Congenital and perinatal cytomegalovirus infections. Reviews of Infectious Diseases, v. 12, n. Supplement_7, p. S745-S753, 1990.

ALVES, L. V.; SOUSA D. C. Crises epilépticas em crianças com síndrome congênita do Zika vírus. Revista Brasileira de Saúde Materna Infantil, v. 16, [s/n], p. 33-37, 2016.

ALViNO, A. C. M. I.; MELlO, L. R. M. de; OliVEIRA, J. do A. M. M. de. Associação de artrogripose em neonatos com microcefalia pelo Zika vírus - série de casos. Revista

Brasileira de Saúde Materno Infantil, Recife, v. 16, supl. 1, p. S83-S88, 2016. Disponível em <http://www.scielo.br/scielo.php?script=sci_arttext\&pid=S1519-

$38292016000800007 \& \operatorname{lng}=e n \& n r m=i s o>$. Acesso em 22 Dec. 2018.

ASHW, A. L. S. et al. Practice parameter: evaluation of the child with microcephaly (an evidence-based review) report of the quality standards Subcommittee of the American Academy of neurology and the practice Committee of the Child Neurology

Society. Neurology, v. 73, n. 11, p. 887-897, 2009.

BALM, M. N. D. et al. A diagnostic polymerase chain reaction assay for Zika virus. Journal of medical virology, v. 84, n. 9, p. 1501-1505, 2012.

BARBAS, D. da S. et al. Determinantes do peso insuficiente e do baixo peso ao nascer na cidade do Rio de Janeiro, Brasil, 2001. Epidemiologia e Serviços de Saúde, v. 18, n. 2, p. 161-170, 2009.

BARKOVICH, A. J. Current concepts of polymicrogyria. Neuroradiology, v. 52, n. 6, p. 479-487, 2010.

BARKOVICH, A. J. et al. Classification system for malformations of cortical development Update 2001. Neurology, v. 57, n. 12, p. 2168-2178, 2001. 
BASURKO, C. et al. Maternal and foetal consequences of dengue fever during pregnancy. European Journal of Obstetrics \& Gynecology and Reproductive Biology, v. 147, n. 1, p. 29-32, 2009.

BESNARD, M. et al. Evidence of perinatal transmission of Zika virus, French Polynesia, December 2013 and February 2014. Eurosurveillance, v. 19, n. 13, p. 20751, 2014.

BETTIOL, H. et al. Epidemiologia do nascimento pré-termo: tendências atuais. Revista Brasileira de Ginecologia e Obstetrícia, v. 32, n. 2, p. 57-60, 2010.

BIELAS, S. et al. Cortical neuronal migration mutants suggest separate but intersecting pathways. Annul Review of Cell and Developmental biology, v. 20, p. 593-618, 2004.

BORGES, M. A. et al. Urban prevalence of epilepsy: populational study in Sao Jose do Rio Preto, a medium-sized city in Brazil. Arquivos de neuro-psiquiatria, v. 62, n. 2A, p. 199204, 2004.

BOTELHO, A. C. G. et al. Infecção congênita presumível por Zika vírus: achados do desenvolvimento neuropsicomotor-relato de casos. Revista Brasileira de Saúde Materno Infantil, p. 39-44, 2016.

BRASIL. Ministério da Saúde. Protocolo de atenção à saúde e resposta à ocorrência de microcefalia relacionada à infecção pelo vírus Zika. Brasília, 2016.

BRITANOVA, O. et al. A novel mode of tangential migration of cortical projection neurons. Developmental biology, v. 298, n. 1, p. 299-311, 2006.

BRUNONI, D. et al. Microcefalia e outras manifestações relacionadas ao vírus Zika: impacto nas crianças, nas famílias e nas equipes de saúde. Ciência \& Saúde Coletiva, v. 21, [s/n] p. 3297-3302, 2016.

BYSTRON, I.; BLAKEMORE, C.; RAKIC, P. Development of the human cerebral cortex: Boulder Committee revisited. Nature Reviews Neuroscience, v. 9, n. 2, p. 110, 2008.

CAFFREY, J. R. et al. An in silico agent-based model demonstrates Reelin function in directing lamination of neurons during cortical development. Plos one, v. 9, n. 10, p. 110-415, 2014. 
CAMARGO Jr, K. R. Zika, microcefalia, ciência e Saúde Coletiva. Physis, v. 26, n. 1, p. 9$10,2016$.

CARDOSO, C. W. et al. Outbreak of exanthematous illness associated with Zika, chikungunya, and dengue viruses, Salvador, Brazil. Emerging infectious diseases, v. 21, n. 12, p. 2274-2276, 2015.

CARTEAUX, G. et al. Zika virus associated with meningoencephalitis. New England Journal of Medicine, v. 374, n. 16, p. 1595-1596, 2016.

CASTRO, M. C. et al. Implications of Zika virus and congenital Zika syndrome for the number of live births in Brazil. Proceedings of the National Academy of Sciences, p. 61776182, 2018.

COWAN, B. E. et al. The effect of hypotension on brain energy state during prolonged neonatal seizure. Pediatric research, v. 21, n. 4, p. 357, 1987.

CRINO, P. B.; MIYATA, H.; VINTERS, H. V. Neurodevelopmental disorders as a cause of seizures: neuropathologic, genetic, and mechanistic considerations. Brain pathology, v. 12, n. 2, p. 212-233, 2002.

CUNHA, A. A. et al. Fatores associados à asfixia perinatal. RBGO, v. 26, n. 10, 2004.

CUNHA, M. S. et al. First complete genome sequence of Zika virus (Flaviviridae, Flavivirus) from an autochthonous transmission in Brazil. Genome announcements, v. 4, n. 2, p. 1-2, 2016.

DEVAKUMAR, D. et al. Infectious causes of microcephaly: epidemiology, pathogenesis, diagnosis, and management. The Lancet infectious diseases, v. 18, n. 1, p. e1-e13, 2018.

DIAMENT, M. J.; WELLER, M.; BERNSTEIN, R. Candida infection in a premature infant presenting as discitis. Pediatric radiology, v. 12, n. 2, p. 96-98, 1982.

DICK, G. W. A.; KITCHEN, S. F.; HADDOW, A. J. Zika virus (I). Isolations and serological specificity. Transactions of the royal society of tropical medicine and hygiene, v. 46, n. 5, p. 509-520, 1952.

DUARTE, G. Infecção pelo vírus Zika durante a gravidez. Femina, v. 44, n. 1, p. 26-48, 2016. 
DUBOWITZ, L. M. S.; DUBOWITZ, V.; GOLDBERG, C. Clinical assessment of gestational age in the newborn infant. The Journal of pediatrics, v. 77, n. 1, p. 1-10, 1970.

DUBOWITZ, L. M.S.; DUBOWITZ, V.; MERCURI, E. The neurological assessment of the preterm and full-term newborn infant. 2 ed. [s/l]: Cambridge University Press, 1999.

DUBOWITZ, L.; MERCURI, E.; DUBOWITZ, V. An optimality score for the neurologic examination of the term newborn. The Journal of pediatrics, v. 133, n. 3, p. 406-416, 1998.

DUFFY, M. R. et al. Zika virus outbreak on Yap Island, federated states of Micronesia. New England Journal of Medicine, v. 360, n. 24, p. 2536-2543, 2009.

EUROPEAN CENTER FOR DISEASE PREVENTION AND CONTROL. Rapid risk assessment: Zika virus epidemic in the Americas: potential association with microcephaly and Guillain-Barré syndrome. 2015.

FARIA, N. R. et al. Zika virus in the Americas: early epidemiological and genetic findings. Science, p. 1-9, 2016.

FAUCI, A. S.; MORENS, D. M. Zika virus in the Americas-yet another arbovirus threat. New England journal of medicine, v. 374, n. 7, p. 601-604, 2016.

FORSLUND, M.; BJERRE, I. Neurological assessment of preterm infants at term conceptional age in comparison with normal full-term infants. Early Human Development, v. 8, n. 3-4, p. 195-208, 1983.

FUNAYAMA, C. A. R. Exame Neurológico em Crianças. Revista Medicina de Ribeirão Preto, Ribeirão Preto, v. 29, [s/n], p. 32-43, 1996.

FUNAYAMA, C. A. R. Exame neurológico na criança. FUNPEC, 2004.

GARCIA, J. M.; GHERPELLI, J. L. D.; LEONE, C. R. Importância da avaliação dos movimentos generalizados espontâneos no prognóstico neurológico de recém-nascidos prétermo. Jornal de Pediatria (Rio de Janeiro), v. 80, n. 4, p. 296-304, 2004.

GOLIN, M. O.; SOUZA, F. I. S. de; SARNI, R. O. S. Avaliação neurológica pelo método Dubowitz em recém-nascidos prematuros com idade corrigida de termo comparada a de nascidos a termo. Revista Paulista de Pediatria, v. 27, n.4, p. 402-409, 2009. 
GUPTA, A. et al. Hemispheric malformations of cortical development. Neurology, v. 62, n. 6 suppl 3, p. S20-S26, 2004.

HADDERS-ALGRA, M.; BROGREN, E.; FORSSBERG, H. Ontogeny of postural adjustments during sitting in infancy: variation, selection and modulation. The Journal of Physiology, v. 493, n. 1, p. 273-288, 1996.

HILLS, S. L. Transmission of Zika virus through sexual contact with travelers to areas of ongoing transmission — continental United States, 2016. MMWR. Morbidity and mortality weekly report, v. 65, n.8, 2016.

HOLMES, G. L. The long-term effects of seizures on the developing brain: clinical and laboratory issues. Brain and Development, v. 13, n. 6, p. 393-409, 1991.

HOPKINS, B. A qualitative approach to the development of movements during early infancy. Continuity of neural functions from prenatal to postnatal life, v. 30, n. 10, p. 179-197, 1984.

INTERGROWTH-21st Project. The Lancet, v. 384, n. 9946, p. 869-879, 2014.

JOHNSTON, M. V.; MC DONALD, J. W. Metabolic and pharmacological consequences of seizures. In: DODSON, W.E.; POLLOCK, J.M. Pediatric Epilepsy. New York: Demso Public, p.1-15, 1993.

KASKE, T. I.; RUMACK, C. M.; HARLOW, C. L. Imagens do cérebro de neonatos e crianças: Tratado de ultrassonografia diagnóstica. 2 ed. Rio de Janeiro: Guanabara Koogan, p. $1250-7,1999$.

KINDHAUSER, M. K. et al. Zika: the origin and spread of a mosquito-borne virus. Bulletin of the World Health Organization, v. 94, n. 9, p. 675, 2016.

KUNO, G. et al. Phylogeny of the genus Flavivirus. Journal of virology, v. 72, n. 1, p. 73-83, 1998.

LANCIOTTI, R. S. et al. Genetic and serologic properties of Zika virus associated with an epidemic, Yap State, Micronesia, 2007. Emerging infectious diseases, v. 14, n. 8, p. 1232, 2008. 
LEFRÉVE, A. F.B. Contribuição para padronização do exame neurológico do recémnascido normal [tese]. São Paulo: Faculdade de Medicina da Universidade de São Paulo, São Paulo, 1950.

LIMA, F. R. de et al. Estudo comparativo da microcefalia ocasionada pela toxoplasmose e zika vírus. Revista de trabalhos acadêmicos-universo recife, v. 4, n. 2, 2017.

MARINO, J.R. et al. Aspectos epidemiológicos da epilepsia em São Paulo. Arquivos Neuropsiquiatria, v. 44, n. 2, p. 243-54, 1986.

MERCURI, E. et al. The neurological examination of the newborn baby. Early Human Development, v. 81, n. 12, p. 947-756, 2005.

MERCURI, E.; DUBOWITZ, L. Neurological examination of the newborn. Current Paediatrics, v. 9, n. 1, p. 42-50, 1999.

MLAKAR, J. et al. Zika virus associated with microcephaly. New England Journal of Medicine, v. 374, n. 10, p. 951-958, 2016.

MUÑOZ, J. A.; LÓPEZ-MESAS, M.; VALIENTE, M. Minimum handling method for the analysis of phosphorous inhibitors of urolithiasis (pyrophosphate and phytic acid) in urine by SPE-ICP techniques. Analytica chimica acta, v. 658, n. 2, p. 204-208, 2010.

MUSSI, M. M. et al. História natural da infecção pelo vírus ZIKA em gestantes e consequências para a gestação, o feto e a criança. Projeto Zika na Gestação. Núcleo de Estudos sobre infecção Materna, Perinatal e Infantil. Faculdade de Medicina de Ribeirão Preto da Universidade de São Paulo. Ribeirão Preto, 2016.

MUSSO, D. et al. Detection of Zika virus in saliva. Journal of Clinical Virology, v. 68, [s/n], p. 53-55, 2015a.

MUSSO, D. et al. Potential sexual transmission of Zika virus. Emerging infectious diseases, v. 21, n. 2 , p. 359,2015 b.

MUSSO, D.; NILLES, E. J.; CAO-LORMEAU, V.-M. Rapid spread of emerging Z ika virus in the Pacific area. Clinical Microbiology and Infection, v. 20, n. 10, p. O595-O596, 2014.

NASCIMENTO, K. K. et al. Avaliação neurológica de recém-nascidos a termo de baixo risco pelo Método Dubowitz. Arquivos Brasileiros de Ciências da Saúde, v. 36, n. 3, p. 135-139, 2011. 
NOVOA, P. C. R. O que muda na ética em pesquisa no Brasil: Resolução 466/12 do Conselho Nacional de Saúde. Einstein (São Paulo), v. 12, n. 1, p. 7-10, 2014.

NUNES, M. L. et al. Microcephaly and Zika virus: a clinical and epidemiological analysis of the current outbreak in Brazil. Jornal de Pediatria (Versão em Português), v. 92, n. 3, p. 230-240, 2016.

OEHLER, E. et al. Zika virus infection complicated by Guillain-Barre syndrome-case report, French Polynesia, December 2013. Eurosurveillance, v. 19, n. 9, p. 207- 220, 2014.

OLHWEILER, Lygia; SILVA, AR da; ROTTA, Newra Tellechea. Estudo dos reflexos primitivos em pacientes recém-nascidos pré-termo normais no primeiro ano de vida. Arquivo Neuropsiquiatria, v. 63, n. 2-A, p. 294-297, 2005.

OLIVEIRA, C. S. de; VASCONCELOS, P. F. da C. Microcephaly and Zika virus. Jornal de pediatria, v. 92, n. 2, p. 103-105, 2016.

OSTER, A. M. et al. Interim guidelines for prevention of sexual transmission of Zika virusUnited States, v. 65, n. 5, p. 1-2, 2016.

PAN AMERICAN HEALTH ORGANIZATIO. Disponível em < https://www.paho.org/hq/index.php?option=com_content\&view=article\&id=11599:regionalzika-epidemiological-update-americas\&Itemid=41691\&lang=en,2017>. Acesso em: 22 set. 2018.

PAPAGEORGHIOU, A. T. et al. International standards for fetal growth based on serial ultrasound measurements: the Fetal Growth Longitudinal Study of the INTERGROWTH-21st Project. The Lancet, v. 384, n. 9946, p. 869-879, 2014.

PAPAGEORGHIOU, A. T. et al. ISUOG Interim Guidance on ultrasound for Zika virus infection in pregnancy: information for healthcare professionals. Ultrasound in Obstetrics \& Gynecology, v. 47, n. 4, p. 530-532, 2016.

PRECHTL, H. F. R. The neurological examination of the full-term newborn infant: a manual for clinical use from the department of developmental neurology. [ $\mathrm{s} / \mathrm{l}] \mathrm{Cambridge}$ University Press, 1991.

PROCIANOY, R. S.; SILVEIRA, R. de C. Síndrome hipóxico-isquêmica. Jornal de Pediatria (Rio de Janeriro), v. 77, n. Supl 1, p. S63-70, 2001. 
RIBEIRÃO PRETO. Prefeitura Municipal de Ribeirão Preto. Secretaria da saúde. Vigilância em saúde. Divisão de Vigilância Epidemiológica. Boletim epidemiológico. Ribeirão Preto, 2016.

RODRIGUES, M. M.; RODRIGUES, L. C. P. V. Tratado de Neurologia Infantil. Rio de Janeiro: Atheneu, 2017.

ROMEO, S. et al. Genetic variation in PNPLA3 confers susceptibility to nonalcoholic fatty liver disease. Nature genetics, v. 40, n. 12, p. 1461, 2008.

SARNAT, H. B.; SARNAT, M. S. Neonatal encephalopathy following fetal distress: a clinical and electroencephalographic study. Archives of neurology, v. 33, n. 10, p. 696-705, 1976.

SERGIO, R. S. Neuropediatria. 2 ed. São Paulo: Sarvier, 2010.

SILVA, S. O. F. Biodiversidade e interações ecológicas de Haemagogus (Diptera: Culicidae) nas situações de risco de transmissão de Arboviroses no Estado do Rio de Janeiro, Brasil [dissertação]. Instituto Oswaldo Cruz, Fundação Oswaldo Cruz, Rio de Janeiro, 2018.

SOCIEDADE BRASILEIRA DE PEDIATRIA. Disponível em < http://www.sbp.com.br/departamentos-cientificos/endocrinologia/graficos-de-crescimento $>$. Acesso em: 12 set. 2018.

SOUZA, A.S. R. et al. Alterações ultrassonográficas intraútero, crescimento da circunferência cefálica fetal e desfechos neonatais entre casos presumíveis de síndrome da Zika congênita no Brasil. Revista Brasileira de Saúde Materna Infantil, Recife, 16 (Supl. 1) S17-S25, 2016.

STARR, J. G. et al. Inapparent congenital cytomegalovirus infection: clinical and epidemiologic characteristics in early infancy. New England Journal of Medicine, v. 282, n. 19, p. 1075-1078, 1970.

SULLIVAN, N. P. Chikungunya virus \& Zika viruses. 2015. Disponível em 〈http://protocols.sonichealthcare.com/shared/I P625.pdf> Acessado em 20 Out. 2018.

TAN, P. C. et al. Dengue infection in pregnancy: prevalence, vertical transmission, and pregnancy outcome. Obstetrics \& Gynecology, v. 111, n. 5, p. 1111-1117, 2008. 
TASSI, L. et al. Focal cortical dysplasia: neuropathological subtypes, EEG, neuroimaging and surgical outcome. Brain, v. 125, n. 8, p. 1719-1732, 2002.

URZÊDA, R. N. et al. Reflexos, reações e tônus muscular de bebês pré-termo em um programa de intervenção precoce. Revista Neurociências, v. 17, n. 4, p. 319-25, 2009.

VAN DER LINDEN Jr, H. et al. Epilepsy Profile in Infants with Congenital Zika Virus Infection. New England Journal of Medicine, v. 379, n. 9, p. 891-892, 2018.

VARGAS, A. et al. Características dos primeiros casos de microcefalia possivelmente relacionados ao vírus Zika notificados na Região Metropolitana de Recife, Pernambuco. Epidemiologia e Serviços de Saúde, v. 25, p. 691-700, 2016.

VOLPE, J. J. et al. The developing oligodendrocyte: key cellular target in brain injury in the premature infant. International Journal of Developmental Neuroscience, v. 29, n. 4, p. 423-440, 2011.

VRIES, J. I. P. et al. The emergence of fetal behaviour. I. Qualitative aspects. Early human development, v. 7, n. 4, p. 301-322, 1982.

WHITEHORN, J.; SIMMONS, C. P. The pathogenesis of dengue. Vaccine, v. 29, n. 42, p. 7221-7228, 2011.

WHO. WHO Child Growth Standards: Head circumference-for-age, arm circumference-forage, triceps skin fold-for-age and subscapular skin fold-for-age: Methods and development. Geneva: World Health Organization, p. 217, 2007.

WUSTHOFF, C. J. How to use: the neonatal neurological examination. Archives of Disease in Childhood-Education and Practice, v. 98, n. 4, p. 148-153, 2013.

YAMAMOTO, A. Y.; FIGUEIREDO, L. T. M.; MUSSIPINHATA, M. M. Prevalência e aspectos clínicos da infecção congênita por citomegalovírus. Jornal de Pediatria (Rio de Janeiro), v. 75, n. 1, p. 23-28, 1999.

ZANLUCA, C. et al. First report of autochthonous transmission of Zika virus in Brazil. Memórias do Instituto Osvaldo Cruz, Rio de Janeiro, v. 110, n. 4, p. 569-572, 2015. 


\title{
APÊNDICE
}

APÊNDICE I - Termo de Consentimento Livre e Esclarecido

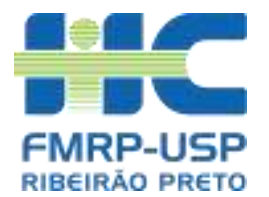

\author{
HOSPITAL DAS CLÍNICAS DA FACULDADE DE MEDICINA \\ DE RIBEIRÃO PRETO DA UNIVERSIDADE DE SÃO PAULO \\ Campus Universitário, Monte Alegre - Fone: 16 3602-1000 - Fax: 16 3602- \\ 1549. \\ CEP 14048-900 RIBEIRÃO PRETO - SÃO PAULO
}

TERMO DE CONSENTIMENTO LIVRE E ESCLARECIDO PARA

BEBÊS NASCIDOS DE MÃES INSCRITAS NO PERÍODO PRÉ-NATAL OU PARTO (COORTE 1) E PARA BEBÊS/CRIANÇAS CUJAS MÃES NÃO APRESENTARAM INFECÇÃO CONFIRMADA PELO VÍRUS ZIKA NA GESTAÇÃO, MAS QUE APRESENTAM MICROCEFALIA, ALTERAÇÕES DO SISTEMA NERVOSO CENTRAL OU ALTERAÇÕES SUGESTIVAS DE INFECÇÃO CONGÊNITA PARA AS QUAIS FORAM EXCLUÍDAS OUTRAS CAUSAS GENÉTICAS OU INFECCIOSAS (COORTE 2).

(Projeto Zika na Gestação - ZIG)

TÍTULO DO ESTUDO: HISTÓRIA NATURAL DA INFECÇÃO PELO VÍRUS ZIKA EM GESTANTES E CONSEQUÊNCIAS PARA A GESTAÇÃO, O FETO E A CRIANÇA.

Investigadores Principais:

Dra. Marisa M. Mussi, Dep. de Puericultura e Pediatria, Universidade de São Paulo, Faculdade de Medicina de Ribeirão Preto, São Paulo, Brasil.

Dra. Aparecida Yulie Yamamoto, Dep. de Puericultura e Pediatria, Universidade de São Paulo, Faculdade de Medicina de Ribeirão Preto, São Paulo, Brasil.

Dr. Geraldo Duarte, Dep. de Ginecologia e Obstetrícia, Universidade de São Paulo, Faculdade de Medicina de Ribeirão Preto, São Paulo, Brasil.

\section{INTRODUÇÃO}

Nós estamos realizando um estudo para entender as causas e consequências de uma infecção viral que aconteceu entre nós nos últimos tempos, a infecção pelo vírus Zika transmitida pelo mosquito Aedes (o mesmo mosquito transmissor da dengue) em mulheres grávidas e seus bebês/suas crianças. Você está sendo convidada a permitir que seu bebê/sua criança participe deste estudo por que há uma suspeita de que você tenha se infectado pelo vírus Zika durante a gestação. Os médicos responsáveis por este estudo em Ribeirão Preto são a Dra. Marisa M. Mussi e o Dr. Geraldo Duarte. Antes de decidir se você deseja que seu bebê/sua criança participe deste estudo, desejamos que você conheça o estudo.

Este documento é chamado termo de consentimento livre e esclarecido, pois, seu consentimento só é válido se for dado após ter sido plenamente esclarecido sobre todos os aspectos relevantes do estudo bem como os riscos e benefícios que ele pode proporcionar. Ele fornece informações sobre este estudo. 
A equipe do estudo conversará com você sobre estas informações. Sinta-se à vontade para fazer perguntas sobre este estudo a qualquer momento. Se você concordar em permitir que seu bebê/sua criança participe deste estudo, pediremos que você assine duas vias desse termo de consentimento livre e esclarecido. Você receberá uma via assinada desse documento para guardar com você e nós guardaremos a outra via. Antes de decidir sobre a participação de seu bebê/sua criança neste estudo, você precisa entender que:

- A participação de seu bebê/sua criança é completamente voluntária;

- Você pode decidir por não permitir que seu bebê/sua criança participe deste estudo ou por decidir que ele deixe o estudo a qualquer hora sem que você ou seu bebê/sua criança tenham qualquer perda no acesso à rotina de cuidados médicos, ou quaisquer outros benefícios.

\section{PORQUE ESTE ESTUDO ESTÁ SENDO FEITO?}

Esse estudo pretende conhecer melhor o que acontece quando uma grávida é infectada pelo vírus chamado Zika. O vírus Zika já é conhecido há muitos anos, mas não havia sido identificado entre nós. Desde o início de 2015, esse vírus está infectando pessoas no Brasil. Esse vírus é transmitido pela picada de um mosquito chamado Aedes Aegypti que é muito comum durante os meses quentes e chuvosos na cidade de Ribeirão Preto. Várias pessoas já tiveram essa infecção em nossa cidade. Algumas pessoas percebem quando estão infectadas, pois, tem febre, mal-estar, dor no corpo, nas juntas e até manchas vermelhas na pele. Normalmente essa doença regride em 3 a 5 dias. No entanto, a maioria das pessoas (60-80\%) nem chega, a saber, que teve infecção por esse vírus Zika, pois, não sente nada. Geralmente, a infecção e a doença causadas pelo vírus Zika não trazem problemas maiores para crianças ou adultos. Até o momento, não há tratamento para essa infecção.

Suspeita-se que o vírus Zika possa ser transmitido pela mulher grávida para seu feto/bebê durante toda a gravidez. Talvez ele possa também ser transmitido durante o nascimento. Esse vírus pode estar ligado a um defeito grave no cérebro do bebê chamado microcefalia (nascimento de bebê com a cabeça muito pequena) em bebês cujas mães tiveram a infecção pelo o vírus Zika enquanto estavam grávidas. Outros problemas também foram detectados entre os fetos/bebês mesmo antes do nascimento, tais como estruturas ausentes ou mal desenvolvidas do cérebro, defeitos nos olhos, defeitos na audição e crescimento prejudicado. Não sabemos exatamente quais são as consequências da infecção pelo vírus Zika durante a gravidez. Não sabemos de que maneira o feto/bebê de mães que estão infectadas pelo vírus Zika durante a gravidez irá adquirir essa infecção, quantos dos bebes infectados teriam problemas, quais seriam esses problemas, quando eles apareceriam, como detectá-los, se quando o bebê ainda está no útero, ao nascer, ou mesmo se algum problema de saúde pode aparecer na criança com mais idade.

Para entender melhor o que vai acontecer com o bebê, e para ser capaz de ajudar as mães e seus bebês, é muito importante observarmos de perto vários recém-nascidos em locais em que muitos casos de infecções por vírus Zika estão ocorrendo. Esta pesquisa ajudará os médicos a entender como a infecção pelo vírus Zika na mulher grávida pode ser transmitida ao bebê e, se transmitida, se o bebê desenvolverá ou não doença.

Nós avaliaremos as crianças ao nascer e acompanharemos três grupos de crianças, todas que nasceram de mães que foram infectadas com o vírus Zika durante a gestação.

Este estudo irá descobrir e avaliar qualquer anormalidade que possa aparecer/ocorrer nos órgãos como o cérebro, olhos, ouvidos e outras partes do corpo dos bebês. Iremos examinar as amostras de sangue, urina e saliva de seu bebê para descobrir se o vírus Zika está presente e também se o corpo do seu bebê produziu substâncias de defesa do sangue (anticorpos) contra 
este vírus. Pretendemos acompanhar e avaliar todos os bebês até a idade de 2 anos, para saber como eles estão crescendo e se desenvolvendo.

Após este estudo, esperamos compreender como os bebês nascidos de mães que tiveram infecção pelo vírus Zika adquirem essa infecção e, se infectados, esses bebês são menos saudáveis do que os bebês nascidos de mães que não tiveram a infecção pelo vírus Zika.

\section{O QUE MEU BEBÊ/MINHA CRIANÇA TEM QUE FAZER COMO PARTICIPANTE DESTE ESTUDO?}

Se você concordar que seu bebê/sua criança participe deste estudo, procuraremos em seu prontuário médico as informações que dizem respeito às condições de nascimento de seu bebê/sua criança e o registro de dados do exame físico ao nascimento, tais como: peso, comprimento, perímetro craniano (medida da cabeça) e o teste de triagem auditiva feito no momento do nascimento. Após 24 horas, mediremos novamente o tamanho da cabeça do seu bebê/sua criança.

Se seu bebê/sua criança for incluído no estudo logo após o nascimento, ainda na sala de parto e após o seu bebê estar bem, caso não tenha sido possível coletar o líquido amniótico na hora do parto (que é o liquido de dentro da bolsa das águas, que banha o bebê e que ele engole dentro do útero), coletaremos um pouco desse líquido amniótico que normalmente fica no estômago do recém-nascido. Para coletar, o pediatra passará uma sonda pela boca da criança até chegar ao estômago e depois de aspirar $1 \mathrm{ml}$ do líquido, essa sonda será retirada.

Se você permitiu a participação de seu bebê/sua criança neste estudo e ele foi incluído nesse estudo logo após o nascimento, antes da alta hospitalar, ou em qualquer outro momento após o nascimento, pediremos a sua permissão para coletar uma pequena quantidade de saliva, colocando levemente um cotonete na boca do seu bebê/sua criança. Além disso, iremos coletar uma pequena quantidade de urina (uma colher de chá), colocando um saco coletor de plástico no genital de seu bebê/sua criança, deixando até que ele tenha urinado. Também será coletada uma pequena quantidade de sangue, cerca de $3 \mathrm{ml}$ (1 colher de chá). Estas amostras serão testadas para a presença do vírus Zika. Os resultados destes testes serão disponibilizados e informados para você por meio de seu médico.

Um pediatra especialista em desenvolvimento do cérebro/neurologista irá examinar e registrar detalhes específicos de seu bebê/sua criança como, por exemplo, a reação que ele apresenta a estímulos, como está os reflexos/nervos de seu bebê/sua criança e qual a posição que ele prefere ficar (exame neurológico). Além disso, profissionais especialistas em desenvolvimento (fisioterapeutas e terapeutas ocupacionais) irão avaliar o desenvolvimento de habilidades e comportamento para a idade. Todos os bebês que forem incluídos no estudo até cerca de 3 meses de vida realizarão pelo menos um exame de ultrassom de crânio. Se no momento que seu bebê/sua criança foi incluída no estudo ele apresentar idade superior a 3 meses ele realizará o exame de Ressonância Magnética (RM) do cérebro. Este exame permite ver detalhadamente o cérebro e se há lesões ou anomalias não visualizáveis por outro exame. A RM será realizada no Centro de Ciências das Imagens e Física Médica do HCFMRP.

Caso seu bebê/sua criança apresente qualquer alteração no exame de ultrassom ou qualquer alteração do desenvolvimento no que diz respeito à idade, um exame de Ressonância Magnética (RM) do cérebro também será feito.

Mesmo que o seu bebê/sua criança não apresente alterações no exame de ultrassom de crânio ele também poderá realizar o exame de RM do cérebro se você tiver feito esse exame de RM durante a sua gestação, devido à sua participação no estudo ainda grávida. Também, mesmo que o seu bebê não tenha alterações no exame de ultrassom ao nascer e você não tenha feito o 
exame de RM durante a gravidez, nós poderemos convidá-lo para fazer RM. Este exame terá a finalidade de identificar as diferenças no exame de RM do cérebro dos bebês que possuem alteração no exame de ultrassom daqueles que não possuem alteração.

Também, um médico oftalmologista irá examinar os olhos do seu bebê/sua criança com um equipamento chamado oftalmoscópio, que permite ver todas as partes dos olhos, para identificar se qualquer alteração está presente.

Um médico cardiologista examinará o coração de seu bebê/sua criança por meio de ultrassom (eco cardiografia) para verificar se há alguma alteração.

Antes da alta hospitalar ou na primeira consulta de seu bebê/sua criança nesse estudo, como parte do atendimento de rotina do hospital, seu bebê vai ser avaliado por um fonoaudiólogo (especialista da voz e da fala) para saber se ele ouve bem. Às vezes, se a primeira avaliação não é conclusiva, se isso acontecer, o exame deverá ser repetido para determinar se o seu bebê ouve bem. Vamos pedir a sua permissão para registrar os resultados dos testes auditivos realizados em seu bebê, sendo que esses dados serão usados também nesse estudo.

O fonoaudiólogo também fará testes para verificar como está o desenvolvimento da comunicação e interação da sua criança (fala e compreensão), a avaliação terá duração entre 1 a 10 minutos com sua presença e serão apresentados estímulos de fala e audição para observação da resposta de seu (ua) filho (a). Também será solicitado que você responda a dois questionários, sobre o desenvolvimento da sua criança, assinalando os itens que considerar verdadeiros.

Dependendo da avaliação do pediatra, seu bebê/sua criança realizará exame do líquido da espinha (líquor ou fluido cerebrospinal). Vamos pedir sua permissão para anotar os resultados destes testes realizados em seu bebê e esses dados serão utilizados também nesse estudo.

Diante de quaisquer alterações encontradas nestes exames, será explicado a você e nós vamos orientá-lo sobre o que pode ser feito para tratar ou recuperar os problemas, sempre que possível.

Seu bebê/sua criança será acompanhado pela equipe do estudo até completar 2 anos (24 meses) de idade. Durante esse tempo, a equipe do estudo avaliará o seu filho cerca de sete vezes, dependendo da idade em que seu bebê/sua criança foi incluído no estudo (nascimento, com 3 a 6 semanas de vida, aos 3 meses, 6 meses, 12 meses, 18 meses e aos 24 meses). Vamos pedir que traga seu bebê/sua criança em determinados dias para a clínica. Cada consulta vai durar cerca de uma hora.

Em cada consulta, a equipe do estudo fará perguntas a você sobre o estado de saúde de seu bebê/sua criança, sobre o crescimento e sobre a exposição a fatores ambientais. Estas perguntas são importantes para determinar se outros fatores podem estar associados às consequências do vírus Zika. Seu bebê/sua criança será examinado (a), anotado os dados de peso, comprimento (estatura/altura) e circunferência (medida) da cabeça. Todos estes dados serão registados e serão utilizados nesse estudo.

Você será solicitada a responder a algumas perguntas sobre como seu bebê/sua criança está fazendo as coisas que ele é capaz de fazer, e qual é a sua impressão sobre o desenvolvimento de seu bebê/sua criança. Vamos também examinar em detalhes como está à posição do corpo de seu bebê/sua criança e como são os músculos, a atenção e a compreensão, ou seja, vamos acompanhar se o desenvolvimento de seu bebê/sua criança está indo no caminho que deveria estar de acordo com a idade. A qualquer momento, se uma alteração for encontrada, a equipe do estudo irá lhe orientar sobre o que e como fazer. 
Se o seu bebê passar no teste da orelhinha que é realizado ao nascimento, ele também será avaliado por fonoaudiólogos (especialista da voz e da fala) aos 6, 12, 18 e 24 meses de idade usando a mesma avaliação que foi feita no momento do nascimento.

Se o seu bebê falhar (não passar) no exame da orelhinha realizado ao nascimento ou em qualquer teste realizado entre 3 e 24 meses, ele será acompanhado por fonoaudiólogos (especialista da voz e da fala). Caso isso ocorra, você terá que vir a clínica mais vezes. Diferentes exames serão realizados com a ajuda de equipamentos especiais que serão colocados no ouvido ou perto da orelha de seu bebê/sua criança para gravar o que ele está ouvindo quando ocorre um som. Estes exames são conhecidos como emissões Otoacústicas, Audiometria e Audiometria Comportamental.

Você saberá os resultados dos testes de audição. Se for confirmado que seu bebê/sua criança tem perda da audição, você será aconselhada pela equipe audiológica (que faz avaliação da audição) sobre o que pode ser feito para seu bebê/sua criança. Ele será encaminhado para a equipe de fonoaudiologia para receber atendimentos que auxiliem na reabilitação da audição.

Nós também pediremos sua permissão para coletar de seu bebê/sua criança amostras de sangue (4 ml-cerca de uma colher de sopa), de saliva (a quantidade necessária para molhar a ponta de um cotonete) e de urina ( $4 \mathrm{ml}$ - cerca de uma colher e meia de sopa). Estas amostras serão testadas ao final do estudo para saber se nelas há o vírus da Zika e se seu bebê/sua criança produziu substâncias de defesa no sangue (anticorpos) contra o vírus Zika. Você receberá os resultados desses testes e será aconselhada sobre eles.

\section{O QUE SERÁ FEITO COM AS AMOSTRAS BIOLÓGICAS GUARDADAS?}

As amostras de sangue, saliva, urina e líquido amniótico (líquido retirado do estômago) de seu bebê/sua criança coletadas durante o estudo serão armazenadas até que seja o momento adequado para que elas sejam processadas de acordo com o que está previsto para o estudo.

Os exames serão feitos nos laboratórios da Faculdade de Medicina de Ribeirão Preto da Universidade de São Paulo. Há exames de medida de anticorpos que ainda não estão disponíveis, mas estão sendo desenvolvidos. Esses exames serão feitos quando estiverem prontos. Enquanto isso, as amostras permanecerão guardadas.

Além disso, se sobrarem após os exames desse estudo, parte de algumas das amostras de seu bebê/sua criança (sangue, saliva e urina) serão armazenadas no freezer, no laboratório de Pediatria do HCFMRP-USP, sob os cuidados da Dra. Aparecida Y. Yamamoto. Essas amostras não serão identificadas com o nome de seu bebê/sua criança, elas receberão um código especial do estudo, chamado de número PID. Os documentos que permitem ligar este código especial aos dados pessoais de seu bebê/sua criança serão mantidos pelos pesquisadores em um local seguro, preservando assim a sua privacidade e a privacidade de seu bebê. Se as amostras biológicas de seu bebê/sua criança forem guardadas no freezer desse laboratório serão parte de um biorrepositório (um local onde as amostras são armazenadas) e só poderão ser acessadas por pesquisadores autorizados. Elas não serão vendidas nem utilizadas diretamente para fabricar produtos comerciais. Você ainda tem os seguintes direitos devido a permitir que seu bebê participe dessa pesquisa e permitir que as amostras biológicas de seu bebê/sua criança sejam armazenadas:

- Receber gratuitamente informações sobre dados obtidos por meio de pesquisa a partir de material biológico armazenado de seu bebê/sua criança, inclusive aquelas de interesse para a saúde de seu bebê/sua criança, para a sua saúde e a de sua família;

- Receber todas as informações sobre as condições de armazenamento desse material.

Caso haja transferência, perda ou destruição das amostras biológicas de seu bebê/sua criança, bem como o encerramento do Biorrepositório, os pesquisadores deverão entrar em contato com você para 
lhe informar. Para poder receber esse resultado você deve notificar à equipe de estudo sobre qualquer mudança em seu endereço ou número de telefone.

\author{
QUANTAS PESSOAS PARTICIPARÃO DESTE ESTUDO? POR QUANTO \\ TEMPO MEU BEBÊ/MINHA CRIANÇA PARTICIPARÁ DESTE \\ ESTUDO? \\ O estudo será conduzido durante 2 (dois) anos. Aproximadamente 300 bebês/crianças \\ participarão do estudo.
}

\title{
POR QUE O MÉDICO PODE RETIRAR MEU BEBÊ/MINHA CRIANÇA DESTE ESTUDO PRECOCEMENTE?
}

O médico do estudo pode ter que retirar seu bebê/sua criança do estudo mais cedo, sem a sua permissão, pelas razões a seguir:

- O resultado do exame para o vírus zika, que foi coletado durante o período em que você estava grávida ou o resultado do exame para o vírus zika coletado para seu bebê/sua criança, fique pronto e seja negativo.

- $O$ (a) pesquisador(a) determinar que a continuação da participação poderá ser prejudicial para a saúde de seu bebê/sua criança e bem-estar. Nesse caso, ele (a) comunicará imediatamente o fato ao Sistema CEP/CONEP e avaliará a necessidade de adequar ou suspender o estudo. O sistema CEP/CONEP são os Comitês de Ética em Pesquisa Brasileiros e são encarregados de garantir a segurança e os direitos dos participantes de pesquisas. O estudo só será suspenso mediante aprovação prévia desses Comitês, salvo em caso de questão urgente de segurança para os participantes, situação na qual a comunicação ao Sistema será feita assim que possível.

- O estudo for cancelado pelo Comitê de Ética em Pesquisa do HCFMRP-USP (CEP) ou pela Comissão Nacional de Ética em Pesquisa (CONEP).

- Seu bebê/sua criança não puder frequentar as consultas, conforme exigido pelo estudo.

Caso isso aconteça, nenhuma outra informação será coletada e nenhuma outra consulta do estudo ou exame laboratorial será feito.

\section{QUAIS SÃO OS RISCOS DO ESTUDO?}

Riscos durante a coleta de sangue

A coleta de sangue pode causar desconforto, sangramento ou hematomas no local da picada da agulha. Um pequeno coágulo pode se formar no local da coleta de sangue e pode haver inchaço na região. Espera-se um pouco de dor no momento da punção (picadinha da agulha) e em alguns casos, podem aparecer manchas roxas após o procedimento, que será realizado por profissionais treinados que tomarão todo cuidado para minimizar estes desconfortos.

\section{Riscos durante a coleta de líquido amniótico no estômago}

A coleta pode causar um leve desconforto no bebê, porém, esse procedimento já foi muito frequentemente usado sem causar riscos. Será passada uma sonda fina e macia pela boca do bebê, ele a engolirá e poderá tossir um pouco. Após ele engolir a sonda, será aspirado lentamente um pouco do líquido que está no estômago e a sonda será rapidamente retirada.

\section{Riscos durante a coleta de saliva}

A coleta de saliva será realizada pela equipe do estudo treinada e capacitada. A saliva será obtida por meio de um cotonete especial com ponta de algodão que será deixado por alguns poucos segundos sob a língua de seu bebê/sua criança até ficar molhado, e então será 
removido. Pode trazer um pequeno desconforto, mas não representa risco para seu bebê/sua criança.

\section{Riscos durante a coleta de urina}

O saco coletor de plástico será colocado no genital de seu bebê/sua criança e deixado até que ele tenha urinado. Pode trazer um pequeno desconforto para seu bebê/sua criança, mas não representa risco para ele.

\section{Riscos ao examinar o ouvido}

Para examinar as partes do ouvido que recebe o som e transfere para o cérebro, serão colocados sensores através de um adesivo perto da região da orelha de seu bebê/sua criança. Estes sensores são ligados a fios que vão para um aparelho que registra as ondas cerebrais para o estímulo ser ouvido. O exame é indolor e o único desconforto é a colocação dos adesivos. Pediremos a você para fazer seu bebê/sua criança dormir. Se ele não conseguir dormir e o exame não puder ser feito porque ele está acordado, precisaremos usar uma pequena quantidade de medicação que fará o seu bebê/sua criança dormir por alguns minutos para ser possível a realização de exames que requerem uma quantidade mínima de movimento. Esta medicação atua normalmente dentro de 10 minutos e a criança permanece sonolenta durante 30 a 50 minutos, após. Os efeitos indesejáveis desta medicação são raros. Em algumas crianças, pode haver vômitos, agitação, pressão arterial mais baixa (sem efeitos sobre a criança). Quando a sedação é necessária, esta será realizada por um médico com experiência em uma sala com todas as condições para a assistência, se necessário.

\section{Riscos ao examinar os olhos}

Os olhos não serão tocados. Um aparelho para olhar dentro dos olhos de seu bebê/sua criança será colocado próximo a ele depois de dilatar (ampliar) a pupila (círculo preto do olho) com um colírio que contém medicação. Como a maioria dos colírios para os olhos, há geralmente uma ardência logo após se pingar a gota. Esta ardência passa rápido, o colírio deixa os olhos sensíveis à luz e visão borrada, porém esses efeitos desaparecem aos poucos. O uso deste colírio em gotas pode ocasionar inchaço da pálpebra e olhos vermelhos. Reações alérgicas são raras. A equipe do estudo está treinada (enfermeira e técnicos de laboratório) para realizar a administração do colírio.

\section{Riscos dos exames de imagem: ultrassom e ressonância magnética}

O ultrassom do crânio (cabeça) é um exame que não causa dor ou problemas ao seu bebê/sua criança. É um exame rápido, que pode ser feito com o seu bebê/sua criança deitado ao seu lado ou no seu colo. Não precisa de nenhum medicamento para ser realizado. O médico que irá fazer o exame colocará um pouco de gel na moleira/fontanela do seu bebê/sua criança e o aparelho de ultrassom vai passar levemente por cima para tirar fotos do cérebro do seu bebê/sua criança. $\mathrm{O}$ exame é rápido e será realizado em uma salinha com luz fraca, preferencialmente com seu bebê/sua criança dormindo e bem coberto.

A ressonância magnética é um exame que não causa dor ou problemas ao seu bebê/sua criança. Entretanto, o fato de ter que ficar sem se mexer dentro do aparelho de ressonância (que tem a forma de um túnel fechado) durante alguns minutos e a sensação de estar em ambiente apertado e com barulho pode ser desagradável para algumas pessoas. Pediremos a você para fazer seu bebê/sua criança dormir. Pediremos que o agasalhe bem e o amamente como faz normalmente em casa logo antes do exame. Caso ele use chupeta, também pediremos que coloque na sua boca. Um protetor de borracha ou algodão será colocado na orelha do seu bebê/sua criança para que o barulho não o atrapalhe. Também o enrolaremos em um lençol, como se faz com os bebês para dormirem. Desta maneira seu bebê/sua criança 
dormirá durante todo exame e talvez nem perceba o barulho da máquina. Não haverá necessidade de pegar veia do seu bebê. Você ou alguém da sua preferência poderá ficar bem pertinho do seu bebê/sua criança durante todo o exame. A equipe está treinada para ajudar você durante a realização deste exame. Se ele não conseguir dormir e o exame não puder ser feito porque ele está mexendo muito precisaremos usar uma pequena quantidade de medicação que fará o seu bebê/sua criança dormir por alguns minutos e possibilitar a realização dos exames sem que o seu bebê/sua criança se mexa muito. Esta medicação atua normalmente dentro de 10 minutos e a criança permanece sonolenta durante 30 a 50 minutos, após. Os efeitos indesejáveis desta medicação são raros. Em algumas crianças, pode haver vômitos, agitação, pressão arterial mais baixa (sem efeitos sobre a criança). Quando for necessário usar esse medicamento, um médico com experiência acompanhará o seu filho que ficará em uma sala com todas as condições para atendimento de seu bebê/sua criança, se for necessário.

\section{HÁ BENEFÍCIOS EM PARTICIPAR DESTE ESTUDO?}

Não há benefícios diretos para seu bebê/sua criança, devido à participação neste estudo. $\mathrm{O}$ resultado desta pesquisa poderá ajudar os médicos a saber o quanto de alterações encontradas em bebês é causada por este vírus, o que ajudará a prevenir tais ocorrências no futuro. Os resultados do estudo e suas conclusões serão divulgados e todos poderão se beneficiar deste conhecimento. Não há tratamento aprovado para os bebês/crianças que adquiriram essa infecção pelo vírus Zika de suas mães.

Seu bebê/sua criança pode se beneficiar de um completo acompanhamento para detecção precoce de deficiências na audição e deficiência visual, ou atraso no desenvolvimento, porque vamos realizar avaliações que não são frequentemente realizadas pelo atendimento de rotina. Além disso, podemos discutir com você as opções de tratamento, como a estimulação ou o uso aparelhos auditivos em fase precoce, quando for necessário.

Iremos oferecer a você o suporte necessário para o tratamento das consequências desta infecção uma vez que o tratamento para a infecção pelo vírus Zika ainda não está disponível.

\section{O QUE ACONTECE SE MEU BEBÊ/MINHA CRIANÇA SOFRER ALGUMA LESÃO?}

Se seu bebê/sua criança sofrer algum dano decorrente deste estudo, o pesquisador proporcionará assistência imediata e integral à sua saúde por danos imediatos ou tardios, diretos ou indiretos, decorrentes do estudo científico, pelo tempo que for necessário. Você não está renunciando a nenhum dos direitos legais de seu bebê ao assinar este termo de consentimento.

\section{E A CONFIDENCIALIDADE?}

$\mathrm{O}$ pesquisador se compromete a assegurar a garantia do sigilo e da confidencialidade dos dados de pesquisa, de acordo com as normas brasileiras e internacionais, com garantia de manter anônimos os dados de seu bebê/sua criança por meio da substituição de toda e qualquer identificação pessoal, como nome, filiação e endereço, pelo número de identificação do estudo chamado de número de PID. Dessa maneira, toda vez que houver necessidade de acesso aos dados da pesquisa por monitores ou auditores, esses serão substituídos por um código que não permitirá identificar que aqueles dados são os do seu bebê/sua criança. Haverá revisões de dados do estudo e, se requerido, vistorias realizadas pelas agências reguladoras brasileiras e internacionais com o intuito de garantir que todos os procedimentos do estudo e parâmetros éticos nacionais e internacionais estão sendo respeitada, inclusive a garantia de sigilo.

\section{QUANTO CUSTARÁ PARA MIM?}

A participação de seu bebê/sua criança neste estudo não trará custos adicionais para você. Você não pagará pelas consultas, exames de ultrassom e exames laboratoriais e aos procedimentos relacionados 
ao estudo. Nem você, nem seu bebê/sua criança receberão nenhum tipo de pagamento por participar neste estudo. O centro de pesquisa poderá se responsabilizar pelos custos decorrentes da participação de seu bebê/sua criança no estudo, para pagar as despesas de transporte e alimentação nos dias em que comparecerem às consultas do estudo, mediante avaliação da assistente social.

\section{QUAIS SÃO OS DIREITOS DO MEU BEBÊ COMO PARTICIPANTE DA PESQUISA?}

A participação neste estudo é completamente voluntária. Você pode optar por não permitir que seu bebê/sua criança participe neste estudo, ou retirá-lo do estudo a qualquer momento. Sua decisão não terá qualquer impacto sobre a participação de seu bebê/sua criança em outros estudos realizados pelo Hospital das Clinicas da Faculdade de Medicina de Ribeirão Preto - HCFMRP-USP e não resultará em nenhuma penalidade ou perda de benefícios aos quais você/seu bebê/sua criança tenha direito. Nós lhe avisaremos sobre novas informações deste ou de outros estudos que possam afetar a saúde de seu bebê/sua criança, bem-estar e vontade de permanecer neste estudo.

\section{O QUE DEVO FAZER SE TIVER DÚVIDAS OU PROBLEMAS?}

Para perguntas sobre este estudo ou sobre quaisquer danos decorrentes do estudo, entre em contato com:

- Profa. Dra. Marisa Márcia Mussi, tel: (16) 3963-6628; (16) 3602-2925; (16) 99778-3425

- Prof. Dr Geraldo Duarte tel: (16) 3602-2588; 3602-2925.

Em caso de dúvidas sobre os seus direitos e de seu (a) filho (a) como participante de pesquisa, entre em contato com:

- Dra. Márcia Guimarães Villanova, Coordenadora do CEP - HCFMRP-USP, (16) 3602-2228.

O CEP é formado por um grupo de pessoas responsáveis por cuidar que uma pesquisa obedeça a todos os critérios éticos durante o seu desenvolvimento. O CEP do HCFMRP-USP está situado no Campus Universitário da USP de Ribeirão Preto, Bairro Monte Alegre, CEP 14048-900, dentro do Hospital das Clínicas do Campus da USP e funciona de segundas às sextas-feiras, das 08:00 às 17:00 horas 


\section{PÁGINAS DE ASSINATURAS - TCLE DO PROJETO ZIG}

Se você leu este Termo de Consentimento (ou se ele foi explicado para você) e entendeu a informação e concorda que seu bebê /sua criança participe, seja voluntário deste estudo, por favor, assine abaixo:

Nome da participante (bebê)

(em letra de forma)

Nome da mãe do participante

(em letra de forma)

\begin{tabular}{llll}
\hline $\begin{array}{l}\text { Assinatura da mãe do } \\
\text { participante }\end{array}$ &
\end{tabular}

$\frac{1}{\text { Data }}$ participante

Nome do pai do participante

(se necessário e em letra de forma)

\begin{tabular}{llll}
\hline $\begin{array}{l}\text { Assinatura do pai } \\
\text { participante }\end{array}$ & do \\
\end{tabular}

$\frac{1}{\text { Data }}$

participante

Responsável legal pelo participante

(se necessário e em letra de forma)

Assinatura do responsável

I I

legal do participante

Pesquisador responsável ou membro da equipe do estudo por ele(a) delegado

(em letra de forma)

Assinatura do pesquisador ou

I I membro da equipe do estudo

Data

Nome da testemunha imparcial

Assinatura da testemunha
imparcial

I

Data

(se necessário, em letra de forma)

imparcial 


\section{ANEXOS}

ANEXO A - HINE - N

(anotar apena RG a lápis]

Avaliaçăo Neurológica Neonatal de Hammersmith - HINE

IDADE:

PC:

DATA AVALIAÇ̄o:

Postura e Tônus

\begin{tabular}{|c|c|c|c|c|c|c|c|}
\hline \multicolumn{6}{|c|}{ Postura e Tônus } & E & A \\
\hline $\begin{array}{l}\text { RECUO DE } \\
\text { BRAço } \\
\text { Pegar ambas as } \\
\text { mãos, estender } \\
\text { rapldamente os } \\
\text { braços paralelo ao } \\
\text { corpo, contar ató } \\
\text { três e soltar. } \\
\text { Repita } 3 \text { vezes. }\end{array}$ & $\begin{array}{l}\text { Braços nào } \\
\text { flexiouam }\end{array}$ & $\begin{array}{l}\text { Bracos flexionam } \\
\text { lentamente, mas } \\
\text { nem sempre, nào } \\
\text { completamente }\end{array}$ & $\begin{array}{l}\text { Bracos flesdonim } \\
\text { lentamente, mas } \\
\text { completarnonte }\end{array}$ & $\begin{array}{c}\text { Braços flexdonam } \\
\text { rápido e } \\
\text { completamente }\end{array}$ & $\begin{array}{l}\text { Bracos com } \\
\text { dificuldade de } \\
\text { eatender, com volta } \\
\text { abrupta. }\end{array}$ & & \\
\hline $\begin{array}{l}\text { TRAÇÁ DO } \\
\text { BRACo } \\
\text { Segure no punho e } \\
\text { puxe o braço para } \\
\text { cima. Observe a } \\
\text { flexdio e a } \\
\text { resistêncla do } \\
\text { cotovelo enquanto } \\
\text { o ombro é } \\
\text { levantado da } \\
\text { mesa. cada lado } \\
\text { Testo cadante. } \\
\text { separadamenta }\end{array}$ & $\begin{array}{l}\text { Braço permanece } \\
\text { reto, nenhuma } \\
\text { resisténcia } \\
\text { observada }\end{array}$ & $\begin{array}{l}\text { Braço flexiona } \\
\text { levemente ou } \\
\text { alguma resistência } \\
\text { observada }\end{array}$ & $\begin{array}{l}\text { Braço flexiona bem } \\
\text { ate elevar o ombro, } \\
\text { seguido por } \\
\text { retificaçào do brago }\end{array}$ & $\begin{array}{l}\text { Braço flexciona } \\
\text { approximadamente } \\
100^{\circ} \text {, mantém } \\
\text { quando o ombro é } \\
\text { elevado } \\
\text { i }\end{array}$ & $\begin{array}{l}\text { Flexcio do braço } \\
<100^{\circ} \text {, mantido } \\
\text { quando o corpo é } \\
\text { levantado }\end{array}$ & & \\
\hline $\begin{array}{l}\text { TRAḈio DA } \\
\text { PERNA } \\
\text { Segure } \\
\text { tornozelo e puxe } \\
\text { lentamente a } \\
\text { perna para cima } \\
\text { Observar a flexảo } \\
\text { do foello e a } \\
\text { resisténcia do } \\
\text { quadril para } \\
\text { elevaçajo Testar } \\
\text { cada lado } \\
\text { separadamente. }\end{array}$ & $\begin{array}{c}\text { Perna reta, sem } \\
\text { resistóncia } \\
\text { observada }\end{array}$ & $\begin{array}{l}\text { Perna leventente } \\
\text { fletida ou alguma } \\
\text { resistèncía } \\
\text { observada }\end{array}$ & $\begin{array}{l}\text { Perna bem fletida } \\
\text { até olevar o quadril }\end{array}$ & $\begin{array}{l}\text { Joelho fletidoe } \\
\text { permanece fletido } \\
\text { quando o quadril é } \\
\text { elevado }\end{array}$ & $\begin{array}{l}\text { Flexào se mantérn } \\
\text { quando o quadril e as } \\
\text { costas sajo levantadas }\end{array}$ & & \\
\hline
\end{tabular}




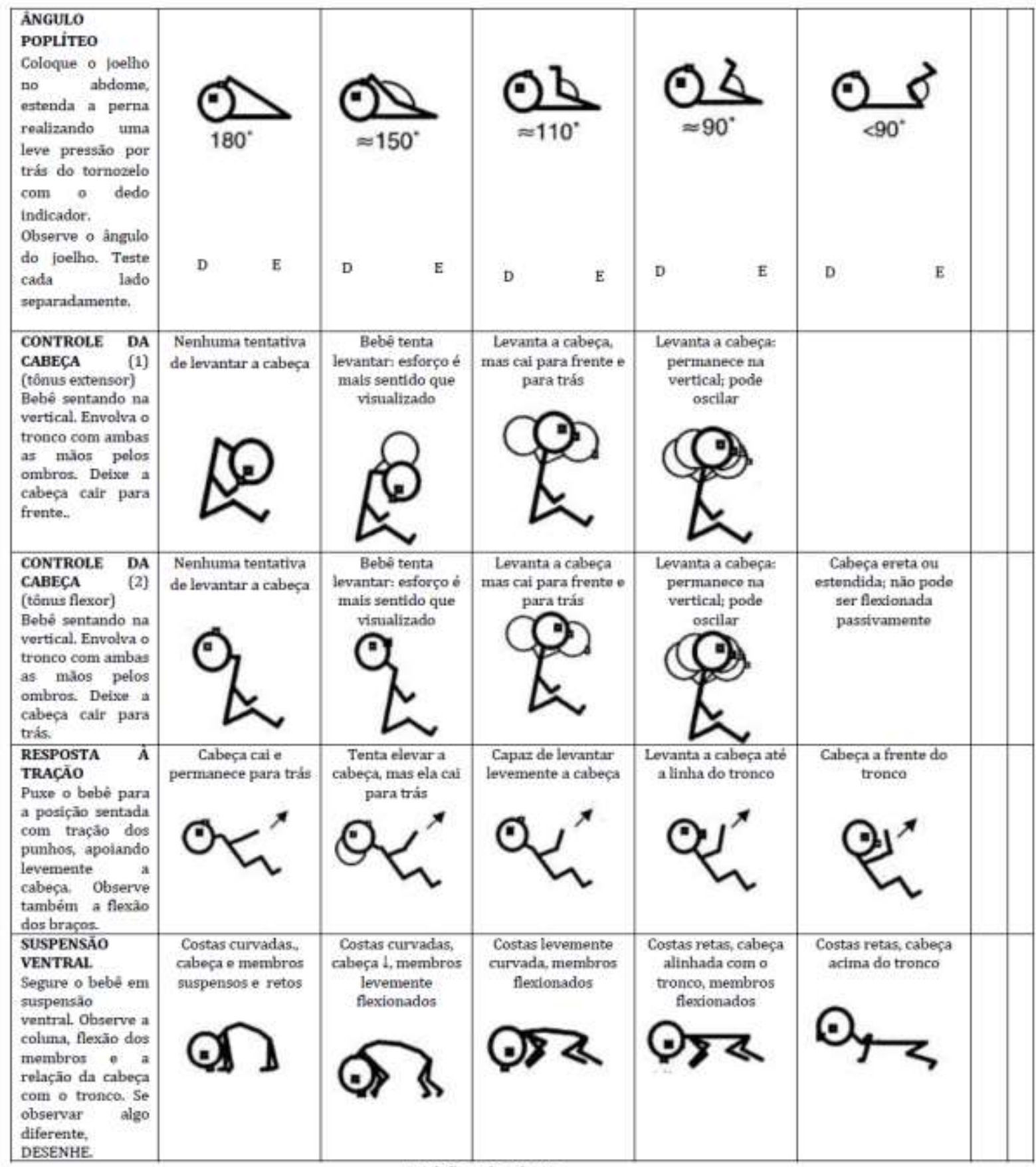

Padrōes de tônus

\begin{tabular}{|c|c|c|c|c|}
\hline $\begin{array}{l}\text { TONUS FLEXOR (1) } \\
\text { (tração: braço X perna) } \\
\text { Compare pontuação da } \\
\text { traçăto do braço com } \\
\text { traçăo de perna }\end{array}$ & $\begin{array}{l}\text { Pontuaçào da flexào } \\
\text { do braço menor que } \\
\text { flexào da perna }\end{array}$ & $\begin{array}{l}\text { Pontuaşào da flexào } \\
\text { do braço igual à } \\
\text { flexảo da perna }\end{array}$ & $\begin{array}{l}\text { Pontuaçăo da flexăo do } \\
\text { braço maior que flexăo da } \\
\text { perna, mas com diferença } \\
\text { de } 1 \text { coluna ou menos }\end{array}$ & $\begin{array}{l}\text { Pontuaçào da flexilo } \\
\text { do braço maior que } \\
\text { flexão da perna, mas } \\
\text { com diferença de maiss } \\
\text { de } 1 \text { coluna }\end{array}$ \\
\hline $\begin{array}{l}\text { TONUS FLEXOR (2) } \\
\text { (braço } X \text { perma) } \\
\text { Postura em supino }\end{array}$ & & $\begin{array}{l}\text { Braços e pernas } \\
\text { flexionados }\end{array}$ & $\begin{array}{l}\text { Forte flexalo dos braços } \\
\text { com forte extersiaio das } \\
\text { pernas - intermitente }\end{array}$ & $\begin{array}{l}\text { Forte flexilo dos } \\
\text { braços corn forte } \\
\text { extensio das pernas- } \\
\text { continua }\end{array}$ \\
\hline
\end{tabular}




\begin{tabular}{|c|c|c|c|c|}
\hline $\begin{array}{l}\text { TONUS EXTENSOR DA } \\
\text { PERNA } \\
\text { Compare a pontuaçâo da } \\
\text { traçào da porna e ângulo } \\
\text { poplíteo }\end{array}$ & $\begin{array}{l}\text { Pontuaçà da traçào } \\
\text { da perna maior que } \\
\text { pontuaçào do ângulo } \\
\text { popliteo }\end{array}$ & $\begin{array}{l}\text { Pontuaçăo da traç̆o } \\
\text { da perna igual que } \\
\text { pontuacăo do ângulo } \\
\text { popliteo }\end{array}$ & $\begin{array}{l}\text { Pontuaçào da traçào da } \\
\text { perna menor que } \\
\text { pontuacão do àngulo } \\
\text { poplitoo, mas com } \\
\text { diferença de } 1 \text { coluna }\end{array}$ & $\begin{array}{l}\text { Pontuaça da traçăo } \\
\text { da perna menor que } \\
\text { pontuacào do ângulo } \\
\text { popliteo, mas con } \\
\text { diferença de mais de } 1 \\
\text { columa }\end{array}$ \\
\hline $\begin{array}{l}\text { TÓNUS EXTENSOR } \\
\text { CERVICAL (sentado) } \\
\text { Compare a pontuaçăo do } \\
\text { controle da cabeşa } 1 \text { e } 2\end{array}$ & $\begin{array}{l}\text { Pontuação de extensão } \\
\text { da cabeça menor que } \\
\text { de flexão da cabeça }\end{array}$ & $\begin{array}{c}\text { Pontuação de } \\
\text { extensio de cabeça } \\
\text { igual à de flexào da } \\
\text { cabeça }\end{array}$ & $\begin{array}{l}\text { Pontuação de extensão da } \\
\text { cabeça maior que de } \\
\text { flexão da cabeça, mais } 1 \\
\text { coluna diferente ou menos }\end{array}$ & $\begin{array}{l}\text { Poutuação de mctensaio } \\
\text { da cabeça major que } \\
\text { de flexảo da cabeça, } \\
\text { mas com diforença } \\
\text { mator que } 1 \text { coluna }\end{array}$ \\
\hline $\begin{array}{l}\text { AUMENTO DO TÓNUS } \\
\text { EXTENSOR (horizontal) } \\
\text { Compare pontuaçào da } \\
\text { resposta à traçio e } \\
\text { suspensão ventral }\end{array}$ & $\begin{array}{c}\text { Pontuaçào da } \\
\text { suspensăo ventral } \\
\text { menor que da resposta } \\
\text { à tração }\end{array}$ & $\begin{array}{c}\text { Pontuaçăo da } \\
\text { suspensăo ventral } \\
\text { igual à da resposta à } \\
\text { tração }\end{array}$ & $\begin{array}{l}\text { Pontuaça da suspensio } \\
\text { ventral malor que da } \\
\text { resposta à traça, mas } \\
\text { com diferença de } 1 \text { coluna } \\
\text { ou menos }\end{array}$ & $\begin{array}{l}\text { Poutuaçăo da } \\
\text { suspensăo ventral } \\
\text { maior que da resposta } \\
\text { à tração, mas com } \\
\text { diferença maior que } 1 \\
\text { coluna }\end{array}$ \\
\hline
\end{tabular}

\section{Reflexos}

\begin{tabular}{|c|c|c|c|c|c|}
\hline $\begin{array}{c}\text { REFLEXOS TENDÍNEOS } \\
\text { Testar bicipital, } \\
\text { patelar e aquileano }\end{array}$ & Ausente & $\begin{array}{l}\text { Sentido, mas } \\
\text { năo } \\
\text { visualizado }\end{array}$ & Visualizado & $\begin{array}{l}\text { "Exasigerado" } \\
\text { (mutito ativo) }\end{array}$ & Ciónus \\
\hline $\begin{array}{c}\text { REFLEXO SUCC,AO/R. } \\
\text { GAG } \\
\text { Colocar o dedo mínimo na } \\
\text { boca do bebs, polpa do } \\
\text { dodo para cima }\end{array}$ & $\begin{array}{l}\text { R. Sucção R. } \\
\text { GAG ansente }\end{array}$ & $\begin{array}{l}\text { R. Sucção } \\
\text { fracoe } \\
\text { frregular. } \\
\text { Näo remove } \\
\text { a boca do } \\
\text { eatimulo }\end{array}$ & $\begin{array}{c}\text { R. Sucção fraco e } \\
\text { regular. } \\
\text { Remove a boca do } \\
\text { estimulo algumas vezes }\end{array}$ & $\begin{array}{l}\text { R. Succioio forte: } \\
\text { a) irregular } \\
\text { b) regular } \\
\text { Remove } \\
\text { adequadamente a boca } \\
\text { do estimulo }\end{array}$ & $\begin{array}{l}\text { Nìo suga, mas } \\
\text { apresenta forte } \\
\text { "pega" }\end{array}$ \\
\hline $\begin{array}{l}\text { PREENSÁO PALMAR } \\
\text { Coloque o dedo indicador } \\
\text { na palma da mão e } \\
\text { presstone gentilmente. } \\
\text { Năo toque a superficie } \\
\text { dorsal. Teste cada lado } \\
\text { separadamente. }\end{array}$ & D E & $\begin{array}{l}\text { Flexáo dos } \\
\text { dedos curta } \\
\text { e fraca }\end{array}$ & Flexdo dos dedos forte & $\begin{array}{c}\text { Flexăo dos dedos forte, } \\
\text { ombros } 1\end{array}$ & $\begin{array}{l}\text { Preens à muito } \\
\text { forte; bebó pode } \\
\text { ser levantado da } \\
\text { superficie } \\
\text { D E }\end{array}$ \\
\hline $\begin{array}{c}\text { PREENSÁo PLANTAR } \\
\text { Pressione o polegar na } \\
\text { sola do pé, abaixo dos } \\
\text { dedos. Teste cada lado } \\
\text { separadamente. }\end{array}$ & Sem resposta & $\begin{array}{l}\text { Flexio } \\
\text { plantar } \\
\text { parcial dos } \\
\text { dedos } \\
\text { D E }\end{array}$ & $\begin{array}{l}\text { Dedos curvam sobre o } \\
\text { dedo do examinador } \\
\begin{array}{ll}\text { D } & \text { E }\end{array}\end{array}$ & & \\
\hline $\begin{array}{l}\text { COLOCACÁO PLANTAR } \\
\text { Levante o bebé para na } \\
\text { posiçào vertical e bata o } \\
\text { dorso do pé contra a } \\
\text { borda de uma superficle } \\
\text { plana. Teste cada lado } \\
\text { separadamente. }\end{array}$ & D E & $\begin{array}{l}\text { Somento } \\
\text { dorsiflexiāo } \\
\text { do tornozelo }\end{array}$ & $\begin{array}{l}\text { Completa resposta de } \\
\text { colocasaio com flextio } \\
\text { do quadrtl e joelho e } \\
\text { colocaçào da sola na } \\
\text { superficie } \\
\text { D E }\end{array}$ & & \\
\hline $\begin{array}{c}\text { REFLEXO DE MORO } \\
\text { Uma mão suporta a cabeça } \\
\text { do bebé na linha média e a } \\
\text { outra nas costas, Levantar } \\
\text { o bebé a } 45^{\circ} \text { e quando o } \\
\text { bebé estiver relaxado, } \\
\text { deixe a cabeça cair } 10^{\circ} \text {. } \\
\text { Observe a queda. Repita } 3 \\
\text { vezes, }\end{array}$ & $\begin{array}{c}\text { Sem resposta ou } \\
\text { somente abre as } \\
\text { mãos }\end{array}$ & $\begin{array}{l}\text { Abdução } \\
\text { completa } \\
\text { dos ombros } \\
\text { completa e } \\
\text { extensà̃o } \\
\text { dos braços: } \\
\text { sem aduçioio }\end{array}$ & $\begin{array}{c}\text { Abduçiōo completa, mas } \\
\text { aduçajo apenas parcial } \\
\text { ou atrasada }\end{array}$ & $\begin{array}{l}\text { Abdução Parcial dos } \\
\text { ombros e extrensāo dos } \\
\text { braços seguida por } \\
\text { uma aduçào suave }\end{array}$ & $\begin{array}{l}\text { a) mainima abduçäo } \\
\text { au aduçào } \\
\text { b)sem abdução ou } \\
\text { aduçắo; apenas } \\
\text { extensào dos } \\
\text { braços para cima } \\
\text { c) somente adução, } \\
\text { acentuada }\end{array}$ \\
\hline
\end{tabular}

\section{Movimentos}

\begin{tabular}{|c|c|c|c|c|c|}
\hline $\begin{array}{l}\text { MOVIMENTOS } \\
\text { ESPONTÁNEOS } \\
\text { (quantitativo) } \\
\text { Observe o bebê qu supino, }\end{array}$ & $\begin{array}{c}\text { Sem } \\
\text { movimento }\end{array}$ & $\begin{array}{c}\text { Movinentos } \\
\text { espotridicos, curtos e } \\
\text { lsolados }\end{array}$ & $\begin{array}{l}\text { Movimentos } \\
\text { isolados } \\
\text { frequentes }\end{array}$ & $\begin{array}{l}\text { Movimentos } \\
\text { generalizados } \\
\text { frequentes }\end{array}$ & $\begin{array}{c}\text { Movimentos } \\
\text { continuos exagerados }\end{array}$ \\
\hline $\begin{array}{l}\text { MOVIMENTOS } \\
\text { ESPONTÁNEOS } \\
\text { (qualitativo) } \\
\text { Observe o bebê em supina. }\end{array}$ & $\begin{array}{l}\text { Apenas } \\
\text { extensào }\end{array}$ & $\begin{array}{c}\text { Extensôes e } \\
\text { movimentos abruptos } \\
\text { ao acaso; alguns } \\
\text { movimentos suaves }\end{array}$ & $\begin{array}{l}\text { Movimentos } \\
\text { fluentes, mas } \\
\text { monótonos. }\end{array}$ & $\begin{array}{l}\text { Movimentos fluentes } \\
\text { alternados em braços e } \\
\text { permas; boa } \\
\text { variabilidade }\end{array}$ & $\begin{array}{l}\text { Restrito, sincronizado; } \\
\text { mastigaçäo, espasmo } \\
\text { ou outros movimentos } \\
\text { anormais }\end{array}$ \\
\hline
\end{tabular}




\begin{tabular}{|c|c|c|c|c|c|}
\hline $\begin{array}{l}\text { ELEVAÇĀO DA CABECA EM } \\
\text { PRONO } \\
\text { Bebê em prono, cabesa na } \\
\text { linha médí. }\end{array}$ & $\begin{array}{c}\text { Sem } \\
\text { resposta }\end{array}$ & $\begin{array}{l}\text { Bebé rola a cabeça } \\
\text { para o lado, sem } \\
\text { levantar o queixo }\end{array}$ & $\begin{array}{l}\text { Bebé levanta } \\
\text { o quelxo e } \\
\text { rola a cabeca } \\
\text { para o lado }\end{array}$ & $\begin{array}{c}\text { Bebe levanta a cabeça e } \\
\text { o queixo para cima }\end{array}$ & $\begin{array}{c}\text { Bebè eleva a cabeça e } \\
\text { a sustenta }\end{array}$ \\
\hline
\end{tabular}

\section{Padrōes e sinais anormais}

\begin{tabular}{|c|c|c|c|c|c|}
\hline $\begin{array}{l}\text { POSTURAS ANORMAIS } \\
\text { DAS MĀOS E DEDOS DOS } \\
\text { PÉS }\end{array}$ & & $\begin{array}{l}\text { Mãos abertas e } \\
\text { dedos dos pés } \\
\text { retos a mailor parte } \\
\text { do tempo }\end{array}$ & $\begin{array}{c}\text { Màos } \\
\text { fechadas } \\
\text { intermitente } \\
\text { ou polegar } \\
\text { aduzido }\end{array}$ & $\begin{array}{l}\text { Mãos fechadas continua } \\
\text { ou polegar aduzido; } \\
\text { flexdo do dedo indicador, } \\
\text { oposição do polegar }\end{array}$ & $\begin{array}{l}\text { Extensĩo contínua do } \\
\text { hálux ou flexão de } \\
\text { todos os dedos }\end{array}$ \\
\hline TREMOR & & $\begin{array}{l}\text { Semu trernor ou } \\
\text { tremor só quando } \\
\text { chora ou após o R. } \\
\text { de Moro }\end{array}$ & $\begin{array}{l}\text { Tromor } \\
\text { ocasional } \\
\text { quando } \\
\text { acordado }\end{array}$ & $\begin{array}{l}\text { Tremores frequentes } \\
\text { quando acordado }\end{array}$ & Tremores continuos \\
\hline SUSTo & $\begin{array}{l}\text { Sem susto, } \\
\text { mesmo corn } \\
\text { bartulho súbito }\end{array}$ & $\begin{array}{l}\text { Sem sustos } \\
\text { espontäneos, mas } \\
\text { reage a barulho } \\
\text { stibito }\end{array}$ & $\begin{array}{l}2-3 \text { sustos } \\
\text { espontáneos }\end{array}$ & $\begin{array}{l}\text { Mais que } 3 \text { sustos } \\
\text { espontaneos }\end{array}$ & Sustos contínuos \\
\hline
\end{tabular}

Orientação e comportamento

\begin{tabular}{|c|c|c|c|c|c|}
\hline APARÉNCLA DOS OLHOS & Nào abre os olhos & & $\begin{array}{l}\text { Movimentos } \\
\text { conjugado dos } \\
\text { olhos }\end{array}$ & $\begin{array}{l}\text { Transitório: } \\
\text {-nistagmo } \\
\text {-estrabismo } \\
\text {-movimentos oculares } \\
\text { lentos } \\
\text {-sinal do sol poente }\end{array}$ & $\begin{array}{l}\text { Persistente: } \\
\text { - nlstagmo } \\
\text {-estrabismo } \\
\text {-movimentos } \\
\text { oculares lentos, } \\
\text { pupilas anormais }\end{array}$ \\
\hline $\begin{array}{l}\text { ORIENTACAO AUDITIVA } \\
\text { Bebe acordado. Envolvê-lo. } \\
\text { Segure tum chocalho entre } 10 \\
\text { a } 15 \mathrm{~cm} \text { da orelha. }\end{array}$ & Sem reação & $\begin{array}{l}\text { Sobressalto } \\
\text { auditivo; fica } \\
\text { alerta e } \\
\text { acalma-se em } \\
\text { seguida, næo } \\
\text { segue o som }\end{array}$ & $\begin{array}{l}\text { Desvio do ollar, } \\
\text { a cabega pode } \\
\text { virar para o som }\end{array}$ & $\begin{array}{l}\text { Vira a cabeça lentamente } \\
\text { ern dirocio ao estimulo; } \\
\text { busca com olhos; } \\
\text { suavemente }\end{array}$ & $\begin{array}{l}\text { Vira a cabeça } \\
\text { (abruptamente, } \\
\text { com espasmo) e } \\
\text { olhos em direção } \\
\text { ao barulho o } \\
\text { tempo todo. }\end{array}$ \\
\hline $\begin{array}{l}\text { ORIENTACÁO VISUAL } \\
\text { Enrole o bebe e acorde-o com } \\
\text { barulho se necessário ou, } \\
\text { gentilmente com balanço. } \\
\text { Observe se o bobê pode ver e } \\
\text { seguir uma bola vermelha (B) } \\
\text { otu uma tarjeta (T) }\end{array}$ & $\begin{array}{l}\text { Nào segue ou } \\
\text { foca o estimulo }\end{array}$ & $\begin{array}{l}\text { Quleto, foca, } \\
\text { segue } \\
\text { brevemiente } \\
\text { para o lado, } \\
\text { mas perdeo } \\
\text { estimulo } \\
\text { B T }\end{array}$ & $\begin{array}{l}\text { Segue horizontal } \\
\text { e vorticalmento, } \\
\text { não vira a cabeça }\end{array}$ & $\begin{array}{l}\text { Segue horizontal e } \\
\text { verticalmente, vira a } \\
\text { cabeģa }\end{array}$ & Segue em círculo \\
\hline $\begin{array}{l}\text { ALERTA } \\
\text { Teste as respostas do } \\
\text { estimulo visual }(\mathrm{B} \text { ou } \mathrm{T}]\end{array}$ & $\begin{array}{c}\text { Naio responde ao } \\
\text { estimulo }\end{array}$ & $\begin{array}{l}\text { Quando } \\
\text { acordado, olha } \\
\text { apenas } \\
\text { brevemente }\end{array}$ & $\begin{array}{l}\text { Quando } \\
\text { acordado, olha } \\
\text { para o estimulo, } \\
\text { mas o perde }\end{array}$ & $\begin{array}{c}\text { Mostra interesse no } \\
\text { estimulo }\end{array}$ & $\begin{array}{c}\text { Nào cansa } \\
\text { biperreatividade }\end{array}$ \\
\hline $\begin{array}{l}\text { IRRITABIL.IDADE } \\
\text { Resposta ao estímulo }\end{array}$ & $\begin{array}{l}\text { Quifeto o termpo } \\
\text { todo, não se irrita } \\
\text { com nenhum } \\
\text { estimulo }\end{array}$ & $\begin{array}{l}\text { Acordado, } \\
\text { chora, as vezes } \\
\text { quando } \\
\text { manuseado }\end{array}$ & $\begin{array}{l}\text { Chora muitas } \\
\text { vezes quando } \\
\text { manuseado }\end{array}$ & $\begin{array}{l}\text { Chora sempre que } \\
\text { manuseado }\end{array}$ & $\begin{array}{l}\text { Chora mesmo } \\
\text { quando não é } \\
\text { mamuseado }\end{array}$ \\
\hline $\begin{array}{l}\text { CONSOL_ABILIDADE } \\
\text { Consolo para acalmar o bebe }\end{array}$ & $\begin{array}{l}\text { Não chora, } \\
\text { consolo nào ể } \\
\text { necessirio }\end{array}$ & $\begin{array}{l}\text { Chora pouco, } \\
\text { consolo nåo è } \\
\text { necessário }\end{array}$ & $\begin{array}{l}\text { Chora fica } \\
\text { quieto quando } \\
\text { fala com ele }\end{array}$ & $\begin{array}{l}\text { Chora; necessita de colo } \\
\text { para ser consolado }\end{array}$ & $\begin{array}{l}\text { Chorar não pode } \\
\text { ser consolado }\end{array}$ \\
\hline CHORO & $\begin{array}{l}\text { Nao chora todoo } \\
\text { terripo }\end{array}$ & $\begin{array}{c}\text { Apenas } \\
\text { choraminga }\end{array}$ & $\begin{array}{l}\text { Chora para } \\
\text { estimulo, mas } \\
\text { intensidade } \\
\text { normal }\end{array}$ & & $\begin{array}{l}\text { Choro muito alto; } \\
\text { normalmente } \\
\text { continuo }\end{array}$ \\
\hline
\end{tabular}

ESTADO DE CONSCIENCIA (BRAZELTON, 1973) :

()Estado $\mathrm{I}=$ sono profiundo, sem movimentos, resperaç ìo regular

()Estado 2 = sono leve, olhos fechados, algum movimento corporal

()Estado 3 = scnoleato, olbos abrindo e fechando

()Estado $4=$ acordado, ollhos abertos, movimentos corporais mimimos

() Estado 5 in totalmente acordado, movimentos corporsis vigorosos

() Estatlo $6=$ choro 


\begin{tabular}{|c|c|c|c|c|c|}
\hline & $\begin{array}{l}\text { SINAIS DE } \\
\text { ATENCÃO }\end{array}$ & & & & $\begin{array}{l}\text { SINAIS DE } \\
\text { ATENCÃO }\end{array}$ \\
\hline $\begin{array}{l}\text { POSTURA } \\
\text { Bebê em supino. } \\
\text { Observar, } \\
\text { principalmente, } \\
\text { a posição das } \\
\text { pernas, mas, } \\
\text { também, } \\
\text { observe os } \\
\text { braços. Pontuar } \\
\text { a postura } \\
\text { predominante. }\end{array}$ & $\begin{array}{l}\text { Braços e pernas } \\
\text { extendidas ou ou } \\
\text { levemente fletidas }\end{array}$ & $\begin{array}{l}\text { Pernas } \\
\text { levemente } \\
\text { fletidas }\end{array}$ & $\begin{array}{lr}\text { Pernas } & \text { bem } \\
\text { fletidas, mas não } \\
\text { aduzidas }\end{array}$ & $\begin{array}{l}\text { Pernas bem } \\
\text { fletidas e aduzidas } \\
\text { perto do abdome }\end{array}$ & $\begin{array}{cl}\text { Postura anormal: } \\
\text { a) } & \text { opistótono } \\
\text { b) extensão } & \\
& \text { das pernas } \\
& \text { e forte } \\
& \text { flexão dos } \\
& \text { braços }\end{array}$ \\
\hline $\begin{array}{l}\text { TRAÇÃO } \\
\text { BRACCO } \\
\text { Envolver } \\
\text { punho e puxar o } \\
\text { braço para cima. }\end{array}$ & $\begin{array}{l}\text { Braço permanece } \\
\text { esticado, } \\
\text { resistência não é } \\
\text { sentida. }\end{array}$ & $\begin{array}{l}\text { Braço levemente } \\
\text { fletido ou com } \\
\text { alguma } \\
\text { resistência } \\
\text { sentida. }\end{array}$ & $\begin{array}{l}\text { Braço bem fletido } \\
\text { até elevação dos } \\
\text { ombros, seguido } \\
\text { por retificação do } \\
\text { braço }\end{array}$ & $\begin{array}{l}\text { Braço com flexão } \\
\text { aproximada de } \\
100^{\circ} \text {, mantendo os } \\
\text { ombros elevados }\end{array}$ & $\begin{array}{ll}\text { Flexão do braço } \\
\text { menor que } 100^{\circ}, \\
\text { mantendo o corpo } \\
\text { elevado }\end{array}$ \\
\hline 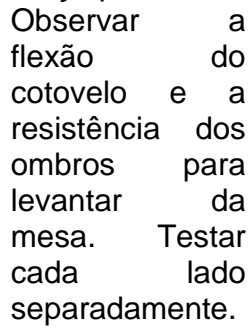 & $\begin{array}{l}\mathrm{D} \\
\mathrm{E}\end{array}$ & $\begin{array}{l}\mathrm{D} \\
\mathrm{E}\end{array}$ & D & $\begin{array}{l}\mathrm{D} \\
\mathrm{E}\end{array}$ & $\sqrt{ }$ \\
\hline $\begin{array}{lr}\text { TRAÇÃO } & \text { DE } \\
\text { PERNA } & \\
\text { Envolver } & \circ \\
\text { tornozelo } & \mathrm{e}\end{array}$ & $\begin{array}{lr}\text { Perna } & \text { retificada, } \\
\text { sem } & \text { resistência } \\
\text { sentida } & \end{array}$ & $\begin{array}{l}\text { Perna } \\
\text { lentamente } \\
\text { fletida ou alguma } \\
\text { resistência }\end{array}$ & $\begin{array}{l}\text { Perna bem fletida } \\
\text { até elevação do } \\
\text { quadril }\end{array}$ & $\begin{array}{l}\text { Joelhos fletidos, } \\
\text { permanecendo } \\
\text { fletido quando o } \\
\text { quadril é elevado }\end{array}$ & $\begin{array}{ll}\text { Sustentação } & \text { da } \\
\text { flexão no retorno e } \\
0 \quad \text { quadril fica } \\
\text { elevado }\end{array}$ \\
\hline \begin{tabular}{lr} 
lentamente \\
puxar a perna \\
para & cima. \\
Observar & a \\
flexão & dos \\
joelhos e & a \\
resistência & do \\
quadril para \\
elevação. Testar \\
cada & lado \\
\multicolumn{2}{l}{ separadamente. }
\end{tabular} & $\begin{array}{l}\mathrm{D} \\
\mathrm{E}\end{array}$ & $\begin{array}{l}D \\
E\end{array}$ & $\mathrm{E}$ & $\begin{array}{l}\mathrm{D} \\
\mathrm{E}\end{array}$ & $\begin{array}{l}D \\
E\end{array}$ \\
\hline $\begin{array}{l}\text { CONTROLE DE } \\
\text { CABEÇA (1) } \\
\text { (tônus extensor) } \\
\text { Bebê sentando } \\
\text { na vertical. } \\
\text { Envolva o tronco } \\
\text { com ambas as } \\
\text { mãos pelos } \\
\text { ombros. Deixe a } \\
\text { cabeça cair } \\
\text { adiante. }\end{array}$ & $\begin{array}{l}\text { Sem esforço para } \\
\text { levantar a cabeça }\end{array}$ & $\begin{array}{lr}\text { Bebê } & \text { tenta: } \\
\text { esforço é melhor } \\
\text { sentido } \\
\text { visualizado }\end{array}$ & $\begin{array}{l}\text { Levanta a cabeça, } \\
\text { mas cai para } \\
\text { frente e para trás }\end{array}$ & $\begin{array}{l}\text { Levanta a cabeça: } \\
\text { permanece na } \\
\text { vertical; pode } \\
\text { oscilar }\end{array}$ & \\
\hline
\end{tabular}




\begin{tabular}{|c|c|c|c|c|c|}
\hline $\begin{array}{l}\text { CONTROLE DE } \\
\text { CABEÇA (2) (tônus } \\
\text { flexor) } \\
\text { Bebê sentando na } \\
\text { vertical. Envolva o } \\
\text { tronco com ambas } \\
\text { as mãos pelos } \\
\text { ombros. Deixe a } \\
\text { cabeça cair para } \\
\text { trás. }\end{array}$ & $\begin{array}{l}\text { Sem esforço para } \\
\text { levantar a cabeça }\end{array}$ & $\begin{array}{l}\text { Bebê tenta: esforço } \\
\text { é melhor sentido } \\
\text { que visualizado }\end{array}$ & $\begin{array}{l}\text { Levanta a cabeça mas } \\
\text { cai para frente e para } \\
\text { trás }\end{array}$ & $\begin{array}{l}\text { Levanta a cabeça: } \\
\text { permanece na vertical; } \\
\text { pode oscilar }\end{array}$ & $\begin{array}{l}\text { Cabeça na vertical ou } \\
\text { extendida; não pode ser } \\
\text { fletida passivamente }\end{array}$ \\
\hline $\begin{array}{l}\text { RESPOSTA } \\
\text { TRAÇÃO } \\
\text { Puxar o bebê para a } \\
\text { posição sentada } \\
\text { pela tração dos } \\
\text { punhos e suportar } \\
\text { levemente } \\
\text { cabeça. Também } \\
\text { observar a flexão } \\
\text { dos braços. }\end{array}$ & $\begin{array}{l}\text { Cabeça caída e } \\
\text { mantida atrás }\end{array}$ & $\begin{array}{l}\text { Tenta elevar a } \\
\text { cabeça, mas ela cai } \\
\text { para trás }\end{array}$ & $\begin{array}{l}\text { Capaz de levantar } \\
\text { levemente a cabeça }\end{array}$ & $\begin{array}{l}\text { Levanta a cabeça até } \\
\text { a linha do corpo }\end{array}$ & $\begin{array}{l}\text { Cabeça a frente do } \\
\text { corpo }\end{array}$ \\
\hline $\begin{array}{l}\text { SUSPENSÃO } \\
\text { VENTRAL } \\
\text { Segurar o bebê em } \\
\text { suspensão ventral. } \\
\text { Observe as costas, } \\
\text { flexão dos membros } \\
\text { e a relação da } \\
\text { cabeça e tronco. Se } \\
\text { observar algo } \\
\text { diferente, } \\
\text { DESENHE. }\end{array}$ & $\begin{array}{l}\text { Costas curvadas, } \\
\text { cabeça e membros } \\
\text { pendurados retos }\end{array}$ & $\begin{array}{l}\text { Costas curvadas, } \\
\text { cabeça } \downarrow \text {, membros } \\
\text { levemente fletidos }\end{array}$ & $\begin{array}{l}\text { Costas levemente } \\
\text { curvada, membros } \\
\text { fletidos }\end{array}$ & $\begin{array}{l}\text { Costas retas, cabeça } \\
\text { alinhada com tronco, } \\
\text { membros fletidos }\end{array}$ & $\begin{array}{l}\text { Costas retas, cabeça } \\
\text { acima do tronco }\end{array}$ \\
\hline $\begin{array}{l}\text { MOVIMENTOS } \\
\text { ESPONTÂNEOS } \\
\text { (qualitativo) } \\
\text { Observar o bebê } \\
\text { em supino. }\end{array}$ & Apenas extensão & $\begin{array}{l}\text { Extensões e } \\
\text { movimentos } \\
\text { abruptos ao acaso; } \\
\text { alguns movimentos } \\
\text { lisos }\end{array}$ & $\begin{array}{l}\text { Movimentos fluentes, } \\
\text { mas monotôno }\end{array}$ & $\begin{array}{l}\text { Movimentos fluentes } \\
\text { alternados em braços } \\
\text { e pernas; boa } \\
\text { variabilidade }\end{array}$ & $\begin{array}{l}\text { Restrito, sincronizado; } \\
\text { boca } \\
\text { trancos ou outro } \\
\text { movimento anormal }\end{array}$ \\
\hline TREMOR & & $\begin{array}{l}\text { Sem tremor ou } \\
\text { tremor só quando } \\
\text { chora ou após o } \\
\text { reflexo de Moro }\end{array}$ & $\begin{array}{l}\text { Tremor } \\
\text { ocasionalmente } \\
\text { quando acordado }\end{array}$ & $\begin{array}{l}\text { Tremores freqüentes } \\
\text { quando acordado }\end{array}$ & Tremor contínuo \\
\hline $\begin{array}{l}\text { REFLEXO DE } \\
\text { MORO } \\
\text { Uma mão suporta a } \\
\text { cabeça do bebê na } \\
\text { linha média e a } \\
\text { outra nas costas. } \\
\text { Levantar o bebê a } \\
45^{\circ} \text { e quando o } \\
\text { bebê estiver } \\
\text { relaxado, deixe a } \\
\text { cabeça cair por } \\
\text { volta de } 10^{\circ} . \\
\text { Observe a queda. } \\
\text { Repetir } 3 \text { vezes. }\end{array}$ & $\begin{array}{l}\text { Sem resposta ou } \\
\text { apenas abre as mãos }\end{array}$ & $\begin{array}{l}\text { Abdução dos } \\
\text { ombros completa e } \\
\text { extensão dos } \\
\text { braços; sem adução }\end{array}$ & $\begin{array}{l}\text { Abdução completa, } \\
\text { mas apenas parcial ou } \\
\text { deficiente adução }\end{array}$ & $\begin{array}{l}\text { Parcial abdução dos } \\
\text { ombros e extensão } \\
\text { dos braços seguida } \\
\text { por adução lisa }\end{array}$ & $\begin{array}{l}\text { a) mínima } \\
\text { abdução ou adução } \\
\text { b) sem abdução } \\
\text { ou adução; apenas } \\
\text { extensão dos braços } \\
\text { para cima } \\
\text { c) marcada por } \\
\text { adução, apenas }\end{array}$ \\
\hline 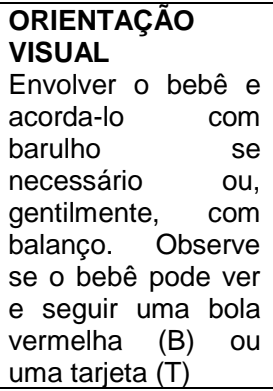 & $\begin{array}{l}\text { Não segue ou foca o } \\
\text { estímulo }\end{array}$ & $\begin{array}{l}\text { Quieto, focaliza, } \\
\text { segue brevemente } \\
\text { para o lado, mas } \\
\text { perde o estímulo } \\
\text { B T }\end{array}$ & $\begin{array}{l}\text { Segue horizontal e } \\
\text { verticalmente, não vira } \\
\text { cabeça }\end{array}$ & $\begin{array}{l}\text { Segue horizontal e } \\
\text { verticalmente, vira a } \\
\text { cabeça }\end{array}$ & Segue em círculo \\
\hline SINAIS ANORMAIS & $\begin{array}{l}\text { Paralisia facial } \\
\mathrm{S} \quad \mathrm{N}\end{array}$ & $\begin{array}{l}\text { Mov. Ocular } \\
\text { Anormal } \\
\mathrm{S} \quad \mathrm{N} \\
\end{array}$ & $\begin{array}{l}\text { Olhar em Sol Poente } \\
\mathrm{S} N\end{array}$ & $\begin{array}{l}\text { Mãos Fechadas } \\
\mathrm{S} N\end{array}$ & Clonus \\
\hline
\end{tabular}


ANEXO C - Aprovação do CEP

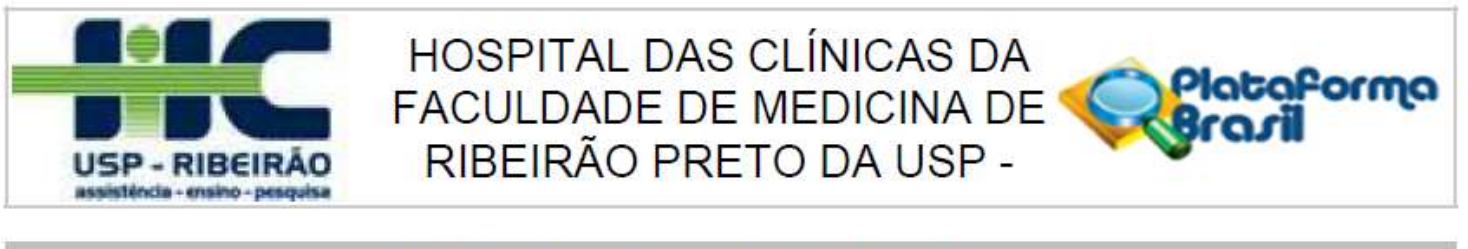

\section{PARECER CONSUBSTANCIADO DO CEP}

\section{DADOS DO PROJETO DE PESQUISA}

Título da Pesquisa: História natural da infecção pelo vírus Zika em gestantes e consequências para a gestação, o feto e a criança

Pesquisador: Marisa Marcia Mussi Pinhata

Área Temática:

Versão: 2

CAAE: 56522216.0 .0000 .5440

Instituição Proponente: Hospital das Clínicas da Faculdade de Medicina de Ribeirão Preto da USP -

Patrocinador Principal: Financiamento Próprio

DADOS DO PARECER

Número do Parecer: 1.604 .787

\section{Apresentação do Projeto:}

Trata-se de projeto de pesquisa a ser desenvolvido pela Professora Doutora Marisa Marcia Mussi Pinhata. Evidências epidemiológicas indicando a possibilidade de associação entre a infecção pelo vírus Zika (ZIKV) e a ocorrência de microcefalia em fetos de mães acometidas por esta infecção configuram situação suficientemente preocupante para demandar a urgente uniáo de forças de todas as áreas da saúde, direta ou indiretamente ligadas ao diagnóstico e cuidado de gestantes e neonatos acometidos por esta infecção(Duarte, 2016). Estes detalhes causaram grande interesse da comunidade cientifica mundial, expressa na recente explosão de publicações sobre este assunto (Pulgarin et al, 2015). No dia 23/03/2016, os dados do Portal da Saúde do Ministério da Saúde indicavam que havia 4293 casos de microcefalia em avaliação no Brasil, fora os 1471 casos já descartados. Sem dúvidas, o processo de responsabilização causal deste agravo não é simples e deve obedecer aos protocolos científicos específicos para esta finalidade. No entanto, dentre os 907 casos já confirmados de microcefalia, aproximadamente 122 exibem uma associação estreita com o diagnóstico da infecção materna prévia pelo ZIKV (PS, 2016). Verificar que a infecção

materna pelo ZIKV estava associada, direta ou indiretamente, à ocorrência de microcefalia foi a mola propulsora para a demanda de uma atenção diferenciada às gestantes portadoras desta

Endereço: CAMPUS UNIVERSITÁRIO

Bairro: MONTE ALEGRE CEP: $14.048-900$

UF: SP Municipio: RIBEIRAO PRETO

Telefone: (16)3602-2228 Fax: (16)3633-1144 E-mail: cep@hcrp.usp.br 


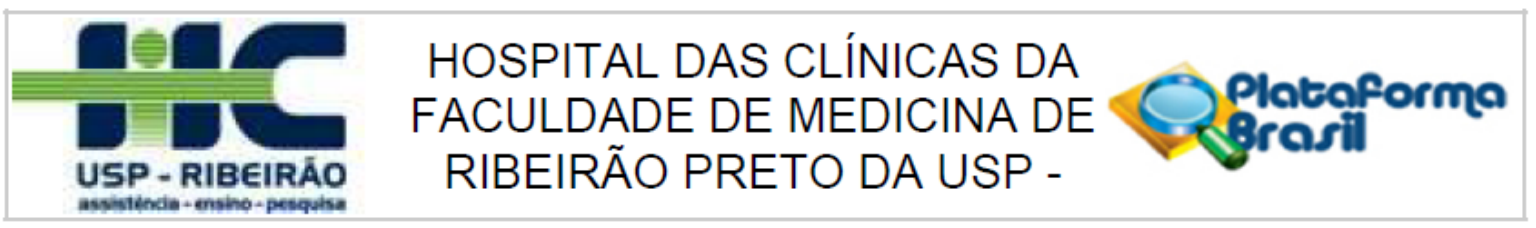

Continuação do Parecer: 1.604.787

infecção. Considerando os agravos para o desenvolvimento intrauterino do sistema nervoso central, há anos o processo reprodutivo em humanos não era atingido de forma tão contundente por um microrganismo (Duarte, 2016). Adicionalmente, para Oliveira Melo et al (2016) a microcefalia causada pelo ZIKV seria apenas a ponta do iceberg, abrindo importante capítulo que precisa ser construído com a produção de conhecimentos sobre a transmissão vertical deste vírus. Realmente, com a evolução do conhecimento sobre o tema até o momento foi possível confirmar uma série de agravos adicionais à saúde perinatal destas crianças, a exemplo da artogripose e lesões difusas no sistema nervoso central destas crianças (MirandaFilho et al, 2016). No entanto, ainda existem muitas perguntas sem respostas. Sem dúvidas, a indefinição se a dualidade diagnóstica entre o ZIKV e a microcefalia deriva de uma associação causal pura, acidental ou incidental induziram considerável número de pesquisas dirigidas para a busca destas respostas (Tetro, 2016; WHO, 2016). Independente se a relação causal entre a infecção materna pelo ZIKV e a ocorrência de microcefalia é direta ou indireta, esta associação foi inicialmente verificada no Brasil, mais precisamente nos Estados de Pernambuco, Paraíba e Bahia (ECDC, 2015; MS, 2015; Oliveira et al, 2015; Calvet et al, 2016). Com base nos levantamentos da vigilância epidemiológica foi possível inferir que havia uma associação entre os dois agravos, visto que a frequência dos casos de microcefalia ocorridos no Brasil em 2015 foi mais de 20 vezes maior do que a taxa deste agravo entre os anos de 2000 a 2014 (PAHO, 2015). Praticamente todos os patógenos, causadores de infecção latente ou adquiridos durante a gestação podem causar infecção fetal, com consequências danosas para o seu desenvolvimento e/ou repercussões tardias. Isso é particularmente prejudicial quando a infecção é transmitida na fase embrionária e fetal precoces. A recente epidemia de microcefalia devida a lesões graves do sistema nervoso central tem sido atribuída à infecção materna gestacional pelo ZIKV. No entanto, vários aspectos da dinâmica dessa

infecção fetal e doença são completamente desconhecidos. A exemplo do que ocorreu para infecções de transmissão vertical causadas por outros agentes, para o enfrentamento dessa trágica situação será necessário confirmar associações, elucidar riscos, mecanismos e consequências, além de confirmar a etiologia viral de eventos adversos gestacionais e fetais, levando-se em consideração outros fatores e outros agentes. A microcefalia possivelmente seja o evento sentinela visível de um acometimento fetal mais amplo e ainda desconhecido. Ainda é necessário buscar evidencias mais robustas que associem a infecção pelo ZIKV gestacional com eventos adversos gestacionais e fetais, além de conhecer quais fatores determinariam acometimentos mais graves nos fetos. Isso só será possível com estudos de coorte que caracterizem detalhadamente a evolução gestacional comparativamente a grupo não infectado por esse vírus.

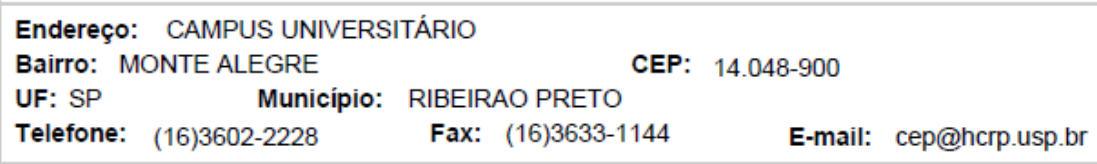




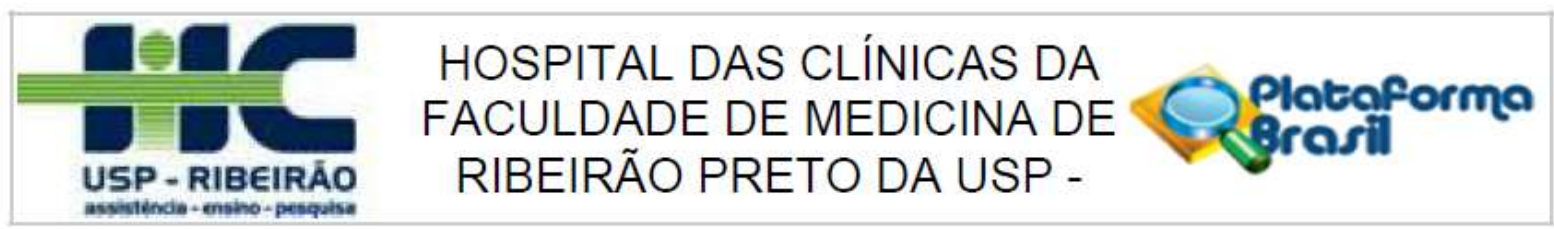

Continuação do Parecer: 1.604 .787

Objetivo da Pesquisa:

Objetivo Primário:

i.Comparar a incidência de eventos adversos gestacionais e fetais entre mulheres que se infectaram com o ZIKV durante a gestação

ii.Determinar o risco de transmissão do ZIKV ao feto após a infecção materna, segundo a idade gestacional. iii.Descrever o amplo espectro das manifestações da infecção congênita em fetos e recém-nascidos de mães infectadas em diferentes estágios da gestação.

iv.Identificar eventuais consequências da infecção congênita pelo ZIKV para a saúde da criança e o seu desenvolvimento até 2 anos de idade.

v. Descrever alterações morfológicas e funcionais do cérebro fetal por ressonância magnética fetal, comparativamente à ultrassonografia, em gestantes infectadas pelo ZIKV.vi.Identificar, por meio de Ressonância Magnética, se há aparecimento ou progressão de lesões do sistema nervoso central na criança (<3meses) quando comparada ao feto entre os expostos à infecção materna pelo ZIKV.

vii.Descrever alterações morfológicas e funcionais de cérebro da criança exposta à infecção materna pelo ZIKV, buscando identificar se essas estão associadas à ocorrência de infecção congênita.

viii.Verificar a incidência e descrever as alterações cardiovasculares anatômicas e funcionais em crianças nascidas de gestações com infecção pelo Zika vírus, buscando identificar se essas estão associadas à ocorrência de infecção congênita.

Objetivo Secundário:

i.Identificar a duração da persistência de excreção do ZIKV no sangue, urina, saliva, secreção vaginal em diferentes momentos gestacionais e no leite no período pós-natal, assim como a cinética de anticorpos IgG e IgM contra o ZIKV em grávidas. ii.Verificar se ocorre coinfecção fetal pelo ZIKV e pelo citomegalovírus e verificar a consequência dessa coinfecção sobre a doença fetal e neonatal, quando comparada à infecção isolada pelo ZIKV.

iii.Buscar a detecção do ZIKV em amostras de saliva, urina e sangue de recém-nascidos

de mães com infecção comprovada durante a gestação visando o diagnóstico precoce da infecção e eventual persistência da replicação viral.iv.Identificar se o ZIKV é excretado no leite materno e se essa pode ser uma fonte de infecção para criança.

v.Identificar potenciais marcadores diagnósticos e prognósticos da infecção congênita pelo ZIKV por neuroimagem tanto no período pré-natal quanto no período pós-natal.

Endereço: CAMPUS UNIVERSITÁRIO

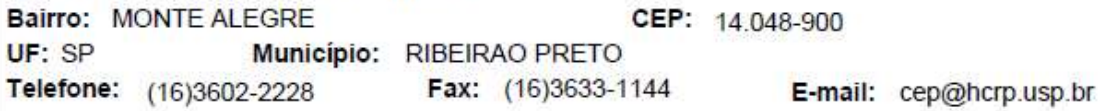




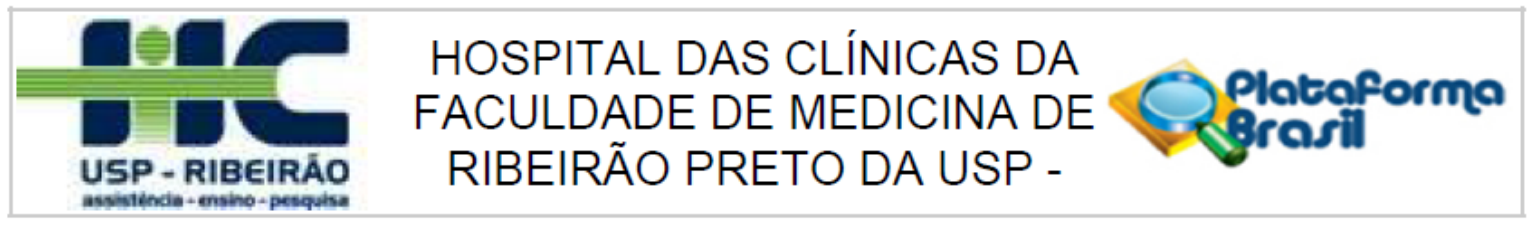

Continuação do Parecer: 1.604.787

\section{Avaliação dos Riscos e Benefícios:}

De acordo com a investigadora principal:

RISCOS DA COORTE MATERNA: - Riscos durante a coleta de sangue: - Riscos durante a coleta de secreção vaginal: - Riscos durante a coleta de saliva: - Riscos durante a coleta de urina: - Riscos durante a coleta de Líquido Amniótico - Riscos para realizar o exame de ultrassonografia- Riscos para realização de exame de Ressonância Magnética (RM):RISCOS COORTE CRIANÇAS:-Riscos durante a coleta de sangueRiscos durante a coleta de líquido amniótico no estômago-Riscos durante a coleta de saliva-Riscos durante a coleta de urina-Riscos ao examinar o ouvido- Riscos ao examinar os olhos- Riscos dos exames de imagem: ultrassom e ressonância magnética

Benefícios: Não há nenhum benefício direto para você por participar deste estudo. O resultado desta pesquisa pode ajudar a entender o que ocorre quando uma mulher grávida adquire o vírus Zika durante a gestação, quanto tempo este vírus permanece nos seus líquidos corporais e por que alguns bebês nascem com este vírus e outros não. Você poderá ajudar no conhecimento para se encontrar uma forma de impedir ou de modificar a infecção em bebê nascidos no futuro. Os resultados do estudo e suas conclusões serão divulgados e todos poderão se beneficiar deste conhecimento. Não há tratamento aprovado para ser usado durante a gestação.

Com relação aos exames de ultrassom durante a gravidez, esse estudo trará informações adicionais do que habitualmente é disponível no cuidado pré-natal feito nas unidades básicas de saúde do município de Ribeirão Preto. Estão previstos vários exames nesse estudo, sendo que um desses exames, chamado de ultrassom morfológico, examinará atentamente se o seu bebê está bem formado ou se há alguma suspeita de alteração. Normalmente, esse exame não é feito. Dessa maneira, os resultados desses exames de ultrassom serão disponibilizados para a gestante e ao seu médico, caracterizando-se como um benefício potencial a você. Sempre que houver informações relevantes ao cuidado da gestante que foi infectada pelo vírus ZIKA geradas pelo estudo, tais como resultados de testes laboratoriais, esses serão disponibilizados para a gestante e ao seu médico. Nós lhe daremos explicações cuidadosas sobre o significado dos resultados dos exames.

\section{Comentários e Consideraçöes sobre a Pesquisa:}

O estudo será desenvolvido na cidade de Ribeirão Preto. Na Folha de Rosto menciona-se a participação de 600 indivíduos. Além de possuir condições climáticas que favorecem a proliferação do vetor Aedes aegypti, a cidade tem vivenciado epidemias do vírus da dengue, também transmitido por esse vetor e atualmente há uma epidemia dessas infecções. Há uma preocupação geral entre os profissionais de saúde e o público sobre o impacto da infecção pelo ZIKV na

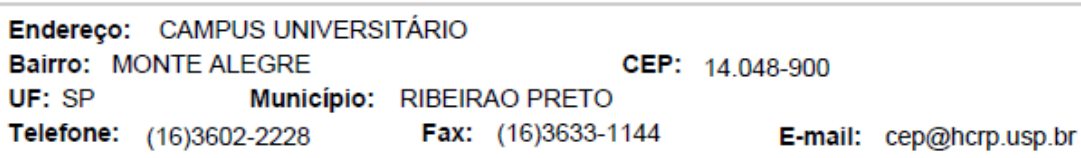




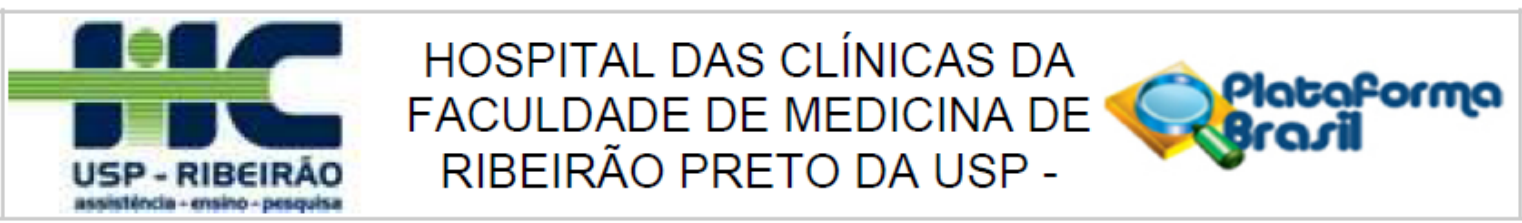

Continuação do Parecer: 1.604.787

gravidez. Segundo o Boletim Epidemiológico Mensal editado pela Prefeitura Municipal de Ribeirão Preto e publicado em 01/03/2016, os dados consolidados até 15/02/2016 indicavam a existência de 5848 habitantes acometidos por dengue durante os meses de janeiro e fevereiro de 2016 . No mesmo período, houve 2326 casos suspeitos de infecção pelo ZIKV, dentre eles 516 gestantes. Considerando-se a possibilidade de que esta epidemia perdure por mais tempo, o risco de infecção em gestantes permanecerá neste e nos anos seguintes. Aquelas gestantes que já tenham sido diagnosticas pelo município como portadoras de infecção pelo ZIKV e os seus filhos expostos, constituirão uma coorte de mulheres com infecção diagnosticada e que serão avaliadas nesse estudo. Em um modelo observacional de coorte prospectivo, este estudo recrutará uma coorte de gestantes que buscaram atendimento pré-natal em unidades básicas de saúde de Ribeirão Preto, que tenham apresentado sinais compatíveis com infecção pelo vírus Zika durante a gestação e tenham sido confirmadas como portadoras dessa infecção por meio de teste de detecção de sequencias genômicas virais no sangue e/ou na urina. Essas serão acompanhadas durante a gravidez e até seis semanas após o parto. Os filhos dessas mulheres constituirão uma coorte de recém-nascidos (Coorte de recém-nascidos de mães que foram infectadas pelo ZIKV). Esse estudo nos permitirá estudar as consequências da infecção pelo ZIKV sobre os desfechos gestacionais, incluindo-se sobre o feto e o recémnascido.

- Coorte materna - Gestantes que já tenham sido diagnosticas como portadoras de infecção pelo ZIKV no município de Ribeirão Preto por terem se tornado sintomáticas em qualquer momento da gestação.

- Coorte de recém-nascidos e crianças cujas mães tiveram infecção comprovada. Todas as crianças das gestantes com infecção confirmada.

As gestantes serão acompanhadas no Ambulatório de Infecções pelo ZIKV em Gestantes (AZIG) do HCFMRP-USP criado especialmente em 04/04/2016 para atender esta nova demanda de Ribeirão Preto e região.

Os recém-nascidos serão acompanhados no ambulatório de Crianças Expostas à Infecção Gestacional pelo vírus Zika (EZIG) que será criado especialmente para esse fim.

i. Coorte materna - Critérios de Inclusão e procedimentos

Pertencerão a essa coorte mulheres grávidas portadoras de infecção confirmada pelo ZIKV, nas quais foi identificada a presença de detecção de RNA viral no sangue ou na urina quando da suspeita médica de síndrome clínica possivelmente causada pelo ZIKV, serem capazes de compreender e cumprir os procedimentos planejados pelo estudo; não serem portadoras de doenças graves como doença psiquiátrica importante não controlada ou que impliquem em

Endereço: CAMPUS UNIVERSITÁRIO

Bairro: MONTE ALEGRE CEP: $14.048-900$

UF: SP Município: RIBEIRAO PRETO

Telefone: (16)3602-2228 Fax: (16)3633-1144 E-mail: cep@hcrp.usp.br 


\section{HOSPITAL DAS CLÍNICAS DA \\ 口四四 \\ USP - RIBEIRÃO \\ FACULDADE DE MEDICINA DE Plotoformo RIBEIRÃO PRETO DA USP -}

Continuação do Parecer: 1.604 .787

procedimentos para o cuidado à saúde frequentes, além da

gravidez. Essas mulheres serão inscritas assim que forem encaminhadas pela Secretaria Municipal de Ribeirão Preto para o ambulatório AZIG do HCFMRP-USP, sob a coordenação do Prof. Dr. Geraldo Duarte. Uma vez selecionadas, planejam-se avaliações mensais ao longo da gestação, seguindo o seguinte esquema, sumarizado na Tabela 1.

Na primeira avaliação será solicitado que as mulheres respondam a perguntas sobre dados demográficos, obstétricos, contatos familiares, doenças sexualmente transmissiveis, alergias, exposição a pessoas com doenças agudas febris, sobretudo aquelas com infecção pelo ZIKV, uso de medicamentos, entre outros. Serão registrados dados de exame físico e realizada ultrassonografia gestacional para confirmação da idade gestacional. Em avaliações clínicas subsequentes, serão feitas perguntas sobre a situação da saúde e sobre a gravidez

Serão obtidas amostras de sangue periférico a partir da primeira avaliação e, mensalmente, em todas as avaliações para testagem da presença de anticorpos contra o ZIKV e para detecção de RNA do ZIKV por meio de teste PCR, além de para outras infecções, quando indicado (Dengue, Chikungunya, Toxoplasmose e Sífilis). As amostras de sangue serão armazenadas para testes sorológicos mais específicos para o ZIKV incluindo-se detectar respostas de anticorpos, de classe $\operatorname{lgM}$ e $\operatorname{lgG}$ à medida que esses testes se tornem disponíveis. Além das amostras de sangue de todas as mulheres e em todas as visitas gestacionais mensais, serão obtidas amostras de saliva, urina e secreções genitais do trato inferior. Essas amostras também serão armazenadas. A ultrassonografia gestacional será repetida mensalmente, abordando aspectos obstétricos e fetais, descritos a seguir

- Determinação precisa da idade gestacional: idealmente pela obtenção do comprimento céfalo-nádega $(\mathrm{CCN})$, quando realizada até 14 semanas. No 20 e 30 trimestres, deve-se comparar a idade calculada pela data da última menstruação (DUM) com a biometria fetal obtida mais precocemente, ficando a cargo do obstetra a definição individualizada da idade gestacional.

- Ultrassonografia inicial até 14 semanas: avaliar $\mathrm{CCN}$, diâmetro biparietal (DBP) e circunferência craniana (CC). Avaliação da anatomia fetal.

- Ultrassonografia inicial após 14 semanas: biometria fetal incluindo DBP, CC, circunferência abdominal (CA) e comprimento do fêmur (CF). Avaliação da anatomia fetal. Aferição dos átrios dos ventrículos laterais e diâmetro transcerebelar (DTC). Registrar achados sugestivos de infecções congênitas, tais como a presença

Endereço: CAMPUS UNIVERSITÁRIO

Bairro: MONTE ALEGRE CEP: $14.048-900$

UF: SP Município: RIBEIRAO PRETO

Telefone: (16)3602-2228 Fax: (16)3633-1144 E-mail: cep@hcrp.usp.br 


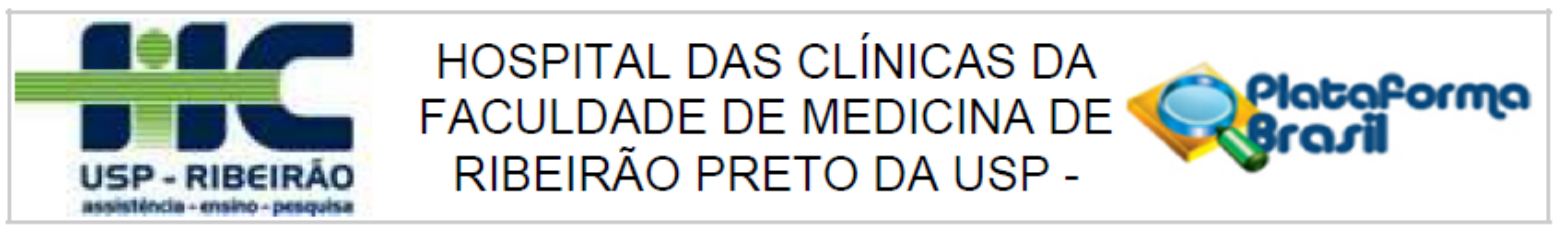

Continuação do Parecer: 1.604.787

de calcificações, hiperecogenicidade intra ou periventricular, alteração das margens ou dimensões dos ventrículos cerebrais.

- Ultrassonografias subsequentes: avaliar os critérios supracitados e descrever alterações observadas sequencialmente.

- Será proposta a aminiocentese a partir da $16^{\mathrm{a}}$ semana para testagem do líquido amniótico para o ZIKV. A Organização Mundial da Saúde e várias outras entidades padronizaram a tabela biométrica fetal internacional do INTERGROWTH-21st Project (Papageorghiou et al. 2014) para o diagnóstico ultrassonográfico antenatal da microcefalia. Havendo suspeita de microcefalia serão utilizados esses critérios de Papageorghiou et al. (2014) (Papageorghiou et al, 2016). Define-se caso suspeito quando o CC fetal estiver abaixo de 2 desvios padrão, ou seja, abaixo do 30 percentil para a idade gestacional. Frente a esta situação, recomenda-se a repetição da avaliação ecográfica dentro de 2 a 3 semanas para confirmação do achado. Nos casos em que a avaliação subsequente demonstrarem CC abaixo de 3 desvios padrão pode-se discutir com a paciente a complementação com ressonância nuclear magnética. Desta coorte serão selecionadas para realização da RM fetal as primeiras 40 gestantes com USG morfológica normal do segundo trimestre realizada entre 18 e 24 semanas e todas nas quais qualquer dos exames ultrassonográficos mostre alterações cerebrais.

A RM fetal será realizada em aparelho de alto campo de 3,0T, com bobinas específicas de corpo de 16 canais entre a 28 a e 32a semana de gestação. O protocolo de aquisição das imagens será: sequências rápidas single-shot ponderadas $\mathrm{T} 2$ nos planos coronal, axial e sagital do encéfalo, sequências ponderadas em T1 e T2 gradiente-eco no plano axial e sequências de difusão, conforme protocolo mínimo estabelecido pela sociedade de radiologia pediátrica e colégio americano de radiologia (ACR-SPR, 2015). As sequências de difusão serão realizadas com aplicação de gradientes em no mínimo 6 direções para se adquirir o tensor de difusão (DTI), sendo assim, possível a avaliação de difusão anisotrópica e, consequentemente a avaliação da maturação da substância branca (Ito et al., 2002; Jakab et al., 2015). As imagens de ressonância magnética serão realizadas no Centro de Ciências das Imagens e Física Médica do Hospital das Clínicas da FMRP-USP e serão revisadas por dois radiologistas experientes do próprio serviço. As imagens serão anonimizadas e as avaliações serão registradas em formulário específico, que ficará armazenado pela equipe de pesquisa com todos os cuidados necessários para preservar a confidencialidade do participante. Os avaliadores serão cegos para os demais dados clínicos dos sujeitos da pesquisa.

O presente projeto de pesquisa está bem fundamentado e adequadamente apresentado.

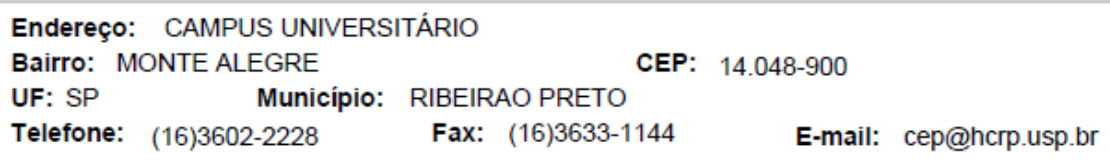




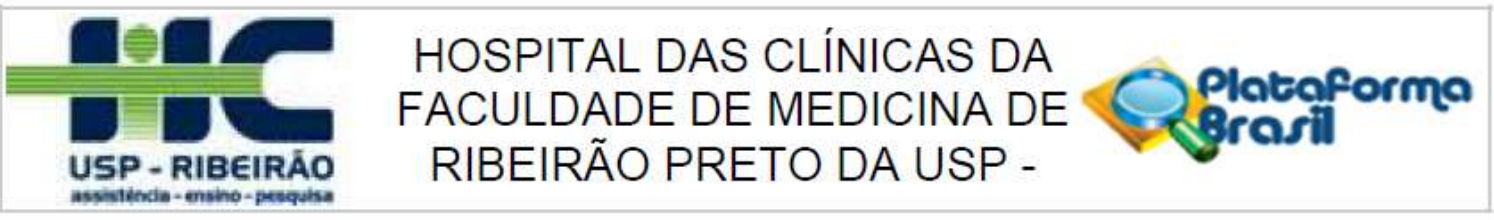

Continuação do Parecer. 1.604.787

\section{Consideraçōes sobre os Termos de apresentação obrigatória:}

A Folha de Rosto foi adequadamente preenchida.

O projeto conta com referencias bibliográficas pertinentes ao tema proposto.

Foi discriminada a equipe da pesquisa que é numerosa, uma vez que se pretende realizar diferentes avaliações por diferentes especialidades médicas.

O orçamento do estudo foi adequadamente apresentado, bem como o cronograma do estudo.

Foi incluída a solicitação para a criação de biorrepositório com seus respectivos responsáveis.

Foram apresentados dois termos de consentimento livre e esclarecido que incluem o termo para guarda de amostras biológicas para o biorrepositório: um dirigido às mulheres grávidas e um dirigido aos pais/responsáveis pelas mulheres grávidas menores de idade. Esses termos incluem as informações sobre a criação de biorrepositório. Além disso, foi incluído termo de consentimento relativo à participação dos bebês nascidos das mulheres gravidas participantes.

Os termo de consentimento/assentimento estão escritos em linguagem adequada, de fácil entendimento. Os propósitos do estudo estão claramente identificados. Todos os procedimentos do estudo estão detalhados, incluindo os potenciais riscos, desconfortos e benefícios.

Os termos incluem a justificativa e a descrição da criação de biorrepositórios, assim como a solicitação de concordância de cada participantes para que sejam guardadas as amostras biológicas. Todavia, um item precisa ser retirado destes termos. Como se trata da criação de biorrepositório, de acordo com a CONEP não é possivel se incluir a opção do participante decidir se quer ou não ser avisado por ocasião de novas pesquisas com o material armazenado (ESTA OPÇÃO SÓ É PERMITIDA PARA BIOBANCOS). PENDÊNCIA ATENDIDA.

Além disso, é necessário que se informe em cada um dos termos de consentimento/assentimento telefone celular de pelo menos um dos pesquisadores. PENDÊNCIA ATENDIDA

\section{Recomendaçöes:}

Não se aplica

Conclusöes ou Pendências e Lista de Inadequaçōes:

Diante do exposto e à luz da Resolução CNS 466/2012, o projeto de pesquisa Zika na Gestação - ZIG, versão 1.0 , de 25 de maio de 2016 pode ser enquadrados na categoria APROVADO, assim como os documentos: Criação de novo biorrepositório para o estudo Zika na gestação - ZIG; Termo de Consentimento Livre e Esclarecido para bebês nascidos de mães inscritas no período pré-natal-versão 1.1 de 22 de Junho de 2016; Termo de Consentimento Livre e Esclarecido para

Endereço: CAMPUS UNIVERSITÁRIO

Bairro: MONTE ALEGRE CEP: $14.048-900$

UF: SP Município: RIBEIRAO PRETO

Telefone: (16)3602-2228 Fax: (16)3633-1144 E-mail: cep@hcrp.usp.br 


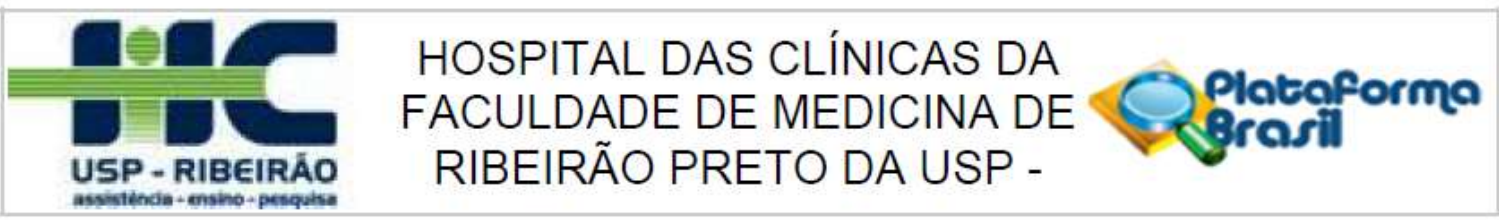

Continuação do Parecer: 1.604 .787

mães inscritas no período pré-natal-versão 1.1 de 22 de Junho de 2016 ; Termo de Consentimento Livre e Esclarecido para pais e responsáveis de gestantes menores de idade inscritas no período pré-natal-versão 1.1 de 22 de Junho de 2016; Termo de Assentimento para menores de idade inscritas no período pré-natalversão versão 1.1 de 22 de Junho de 2016.

\section{Considerações Finais a critério do CEP:}

Projeto Aprovado: Tendo em vista a legislação vigente, devem ser encaminhados ao CEP, relatórios parciais anuais referentes ao andamento da pesquisa e relatório final ao término do trabalho. Qualquer modificação do projeto original deve ser apresentada a este CEP em nova versão, de forma objetiva e com justificativas, para nova apreciação.

Este parecer foi elaborado baseado nos documentos abaixo relacionados:

\begin{tabular}{|c|c|c|c|c|}
\hline Tipo Documento & Arquivo & Postagem & Autor & Situação \\
\hline $\begin{array}{l}\text { Informações Básicas } \\
\text { do Projeto }\end{array}$ & $\begin{array}{l}\text { PB_INFORMAÇÕES_BÁSICAS_DO_P } \\
\text { ROJETO 713821.pdf }\end{array}$ & $\begin{array}{c}22 / 06 / 2016 \\
16: 32: 50 \\
\end{array}$ & & Aceito \\
\hline $\begin{array}{l}\text { TCLE / Termos de } \\
\text { Assentimento / } \\
\text { Justificativa de } \\
\text { Ausência }\end{array}$ & $\begin{array}{l}\text { 4_ZIG_TCLE_Criancas_versao_1_1_22 } \\
\text { Jun2016.docx }\end{array}$ & $\begin{array}{c}22 / 06 / 2016 \\
16: 32: 17\end{array}$ & $\begin{array}{l}\text { Claudinei Coppola } \\
\text { Junior }\end{array}$ & Aceito \\
\hline Outros & $\begin{array}{l}\text { 9_ZIG_alteracoes_marcadas_Termo_as } \\
\text { sentimento_versao_1_1_22Jun2016.pdf }\end{array}$ & $\begin{array}{c}22 / 06 / 2016 \\
16: 30: 24\end{array}$ & $\begin{array}{l}\text { Claudinei Coppola } \\
\text { Junior }\end{array}$ & Aceito \\
\hline Outros & $\begin{array}{l}8 \text { 8IG_alteracoes_marcadas_TCLE_Cri } \\
\text { ancas versao } 11 \text { 22Jun2016.pdf }\end{array}$ & $\begin{array}{c}22 / 06 / 2016 \\
16: 30: 06 \\
\end{array}$ & $\begin{array}{l}\text { Claudinei Coppola } \\
\text { Junior }\end{array}$ & Aceito \\
\hline Outros & 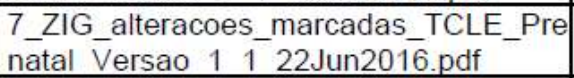 & $\begin{array}{c}22 / 06 / 2016 \\
16: 29: 52 \\
\end{array}$ & $\begin{array}{l}\text { Claudinei Coppola } \\
\text { Junior }\end{array}$ & Aceito \\
\hline Outros & $\begin{array}{l}\text { 6_ZIG_alteracoes_marcadas_TCLE_Pai } \\
\text { s_responsaveis_Prenatal_Versao_1_1_- } \\
\text { 22Jun2016.pdf }\end{array}$ & $\begin{array}{c}22 / 06 / 2016 \\
16: 29: 37\end{array}$ & $\begin{array}{l}\text { Claudinei Coppola } \\
\text { Junior }\end{array}$ & Aceito \\
\hline $\begin{array}{l}\text { TCLE / Termos de } \\
\text { Assentimento / } \\
\text { Justificativa de } \\
\text { Ausência }\end{array}$ & $\begin{array}{l}\text { 5_ZIG_Termo_assentimento_versao_1_ } \\
\text { 1_22Jun2016.docx }\end{array}$ & $\begin{array}{c}22 / 06 / 2016 \\
16: 29: 00\end{array}$ & $\begin{array}{l}\text { Claudinei Coppola } \\
\text { Junior }\end{array}$ & Aceito \\
\hline $\begin{array}{l}\text { TCLE / Termos de } \\
\text { Assentimento / } \\
\text { Justificativa de } \\
\text { Ausência }\end{array}$ & $\begin{array}{l}\text { 3_ZIG_TCLE_Prenatal_Versao_1_1_22 } \\
\text { Jun2016.docx }\end{array}$ & $\begin{array}{c}22 / 06 / 2016 \\
16: 28: 34\end{array}$ & $\begin{array}{l}\text { Claudinei Coppola } \\
\text { Junior }\end{array}$ & Aceito \\
\hline $\begin{array}{l}\text { TCLE / Termos de } \\
\text { Assentimento / } \\
\text { Justificativa de } \\
\text { Ausência }\end{array}$ & $\begin{array}{l}\text { 2_ZIG_TCLE_Pais_responsaveis_Prena } \\
\text { tal_Versao_1_1_22_Jun_2016.docx }\end{array}$ & $\begin{array}{c}22 / 06 / 2016 \\
16: 28: 24\end{array}$ & $\begin{array}{l}\text { Claudinei Coppola } \\
\text { Junior }\end{array}$ & Aceito \\
\hline
\end{tabular}

Endereço: CAMPUS UNIVERSITÁRIO

Bairro: MONTE ALEGRE

UF: SP Município: RIBEIRAO PRETO

Telefone: (16)3602-2228 Fax: (16)3633-1144 E-mail: cep@hcrp.usp.br 


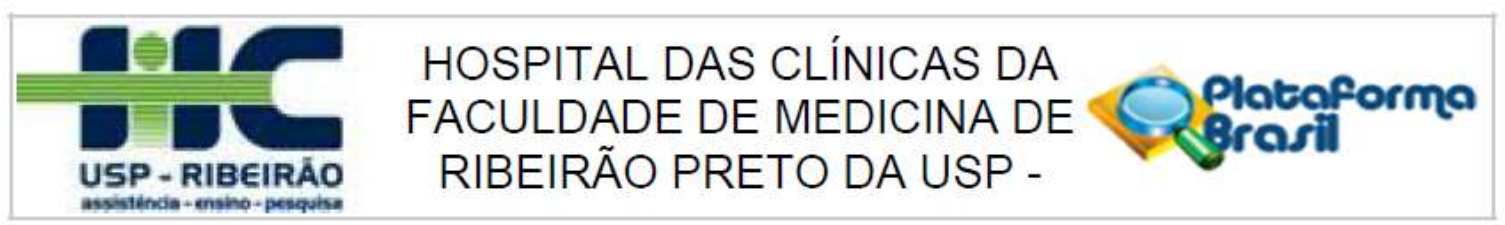

Continuação do Parecer: 1.604 .787

\begin{tabular}{|c|c|c|c|c|}
\hline Outros & $\begin{array}{l}\text { 1_ZIG_Oficio_resposta_pendencias_par } \\
\text { ecer CEP.pdf }\end{array}$ & $\begin{array}{c}22 / 06 / 2016 \\
16: 27: 21\end{array}$ & $\begin{array}{l}\text { Claudinei Coppola } \\
\text { Junior }\end{array}$ & Aceito \\
\hline Outros & $\begin{array}{l}\text { 1_ZIG_Oficio_resposta_pendencias_par } \\
\text { ecer CEP.docx }\end{array}$ & $\begin{array}{c}22 / 06 / 2016 \\
16: 27: 08\end{array}$ & $\begin{array}{l}\text { Claudinei Coppola } \\
\text { Junior }\end{array}$ & Aceito \\
\hline Orçamento & $\begin{array}{l}\text { 15_ZIG_Orcamento_versao_1_0_Final_ } \\
\text { MMM_24Maio16.xIsx }\end{array}$ & $\begin{array}{c}25 / 05 / 2016 \\
17: 15: 09\end{array}$ & $\begin{array}{l}\text { Claudinei Coppola } \\
\text { Junior }\end{array}$ & Aceito \\
\hline Cronograma & 14_ZIG_Cronograma_execucoes.pdf & $\begin{array}{c}25 / 05 / 2016 \\
17: 14: 39 \\
\end{array}$ & $\begin{array}{l}\text { Claudinei Coppola } \\
\text { Junior }\end{array}$ & Aceito \\
\hline Cronograma & 14_ZIG_Cronograma_execucoes.doc & $\begin{array}{c}25 / 05 / 2016 \\
17: 14: 27 \\
\end{array}$ & $\begin{array}{l}\text { Claudinei Coppola } \\
\text { Junior }\end{array}$ & Aceito \\
\hline $\begin{array}{l}\text { TCLE / Termos de } \\
\text { Assentimento / } \\
\text { Justificativa de } \\
\text { Ausência }\end{array}$ & $\begin{array}{l}\text { 13_ZIG_Termo_Assentimento_versao_1 } \\
\text {-0_25_Maio_2016.docx }\end{array}$ & $\begin{array}{l}25 / 05 / 2016 \\
17: 14: 09\end{array}$ & $\begin{array}{l}\text { Claudinei Coppola } \\
\text { Junior }\end{array}$ & Aceito \\
\hline $\begin{array}{l}\text { TCLE / Termos de } \\
\text { Assentimento / } \\
\text { Justificativa de } \\
\text { Ausência }\end{array}$ & $\begin{array}{l}\text { 12_ZIG_TCLE_Pais_responsaveis_Pren } \\
\text { atal_Versao_1_0_25_Maio_2016.docx }\end{array}$ & $\begin{array}{c}25 / 05 / 2016 \\
17: 13: 51\end{array}$ & $\begin{array}{l}\text { Claudinei Coppola } \\
\text { Junior }\end{array}$ & Aceito \\
\hline $\begin{array}{l}\text { TCLE / Termos de } \\
\text { Assentimento / } \\
\text { Justificativa de } \\
\text { Ausência }\end{array}$ & $\begin{array}{l}\text { 11_ZIG_TCLE_Prenatal_Versao_1_0_2 } \\
\text { 5_Maio_2016.docx }\end{array}$ & $\begin{array}{c}25 / 05 / 2016 \\
17: 13: 37\end{array}$ & $\begin{array}{l}\text { Claudinei Coppola } \\
\text { Junior }\end{array}$ & Aceito \\
\hline $\begin{array}{l}\text { TCLE / Termos de } \\
\text { Assentimento / } \\
\text { Justificativa de } \\
\text { Ausência }\end{array}$ & $\begin{array}{l}\text { 10_ZIG_TCLE_Criancas_Versao_1_0_2 } \\
\text { 5_Maio_2016.docx }\end{array}$ & $\begin{array}{c}25 / 05 / 2016 \\
17: 13: 26\end{array}$ & $\begin{array}{l}\text { Claudinei Coppola } \\
\text { Junior }\end{array}$ & Aceito \\
\hline Outros & 9_ZIG_aprovacao_orcamento_UPC.pdf & $\begin{array}{c}25 / 05 / 2016 \\
17: 12: 28\end{array}$ & $\begin{array}{l}\text { Claudinei Coppola } \\
\text { Junior }\end{array}$ & Aceito \\
\hline $\begin{array}{l}\text { Declaração de } \\
\text { Manuseio Material } \\
\text { Biológico / } \\
\text { Biorepositório / } \\
\text { Biobanco }\end{array}$ & $\begin{array}{l}\text { 8_ZIG_Oficio_criacao_biorrepositorio_es } \\
\text { tudo.pdf }\end{array}$ & $\begin{array}{c}25 / 05 / 2016 \\
17: 11: 59\end{array}$ & $\begin{array}{l}\text { Claudinei Coppola } \\
\text { Junior }\end{array}$ & Aceito \\
\hline $\begin{array}{l}\text { Declaração de } \\
\text { Manuseio Material } \\
\text { Biológico / } \\
\text { Biorepositório / } \\
\text { Biobanco }\end{array}$ & $\begin{array}{l}\text { 8_ZIG_Oficio_criacao_biorrepositorio_es } \\
\text { tudo.docx }\end{array}$ & $\begin{array}{c}25 / 05 / 2016 \\
17: 11: 48\end{array}$ & $\begin{array}{l}\text { Claudinei Coppola } \\
\text { Junior }\end{array}$ & Aceito \\
\hline $\begin{array}{l}\text { Declaração de } \\
\text { Manuseio Material } \\
\text { Biológico / } \\
\text { Biorepositório / } \\
\text { Biobanco } \\
\end{array}$ & $\begin{array}{l}\text { 7_ZIG_Declaracao_uso_destino_materi } \\
\text { al_biologico_dados_coletados.pdf }\end{array}$ & $\begin{array}{c}25 / 05 / 2016 \\
17: 11: 32\end{array}$ & $\begin{array}{l}\text { Claudinei Coppola } \\
\text { Junior }\end{array}$ & Aceito \\
\hline $\begin{array}{l}\text { Declaração de } \\
\text { Manuseio Material } \\
\text { Biológico / } \\
\text { Biorepositório / }\end{array}$ & $\begin{array}{l}\text { 7_ZIG_Declaracao_uso_destino_materi } \\
\text { al_biologico_dados_coletados.docx }\end{array}$ & $\begin{array}{c}25 / 05 / 2016 \\
17: 11: 26\end{array}$ & $\begin{array}{l}\text { Claudinei Coppola } \\
\text { Junior }\end{array}$ & Aceito \\
\hline
\end{tabular}

Endereço: CAMPUS UNIVERSITÁRIO

Bairro: MONTE ALEGRE

UF: SP Municipio: RIBEIRAO PRETO

Telefone: (16)3602-2228 Fax: (16)3633-1144 E-mail: cep@hcrp.usp.br 


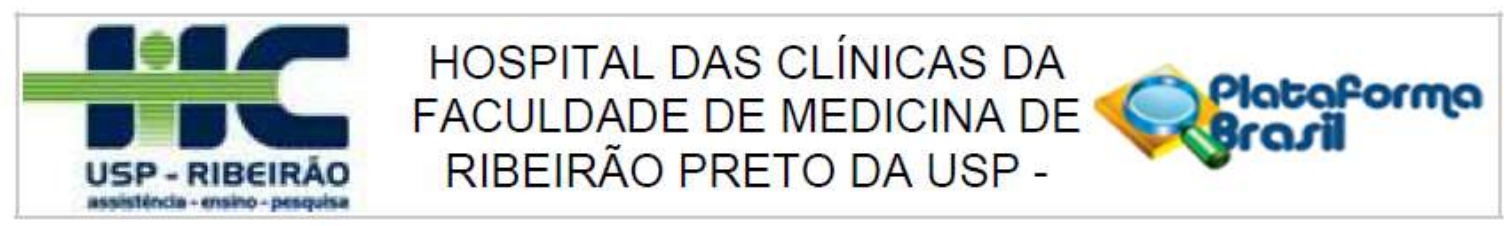

Continuação do Parecer: 1.604.787

\begin{tabular}{|c|c|c|c|c|}
\hline Biobanco & \begin{tabular}{|l} 
7_ZIG_Declaracao_uso_destino_materi \\
al biologico dados coletados.docx
\end{tabular} & $\begin{array}{c}25 / 05 / 2016 \\
17: 11: 26 \\
\end{array}$ & $\begin{array}{l}\text { Claudinei Coppola } \\
\text { Junior }\end{array}$ & Aceito \\
\hline $\begin{array}{l}\text { Declaração de } \\
\text { Manuseio Material } \\
\text { Biológico / } \\
\text { Biorepositório / } \\
\text { Biobanco }\end{array}$ & $\begin{array}{l}\text { 6_ZIG_Declaracao_uso_amostras_arma } \\
\text { zenadas_estudos_futuros.pdf }\end{array}$ & $\begin{array}{l}25 / 05 / 2016 \\
17: 10: 35\end{array}$ & $\begin{array}{l}\text { Claudinei Coppola } \\
\text { Junior }\end{array}$ & Aceito \\
\hline $\begin{array}{l}\text { Declaração de } \\
\text { Manuseio Material } \\
\text { Biológico / } \\
\text { Biorepositório / } \\
\text { Biobanco } \\
\end{array}$ & $\begin{array}{l}\text { 6_ZIG_Declaracao_uso_amostras_arma } \\
\text { zenadas_estudos_futuros.docx }\end{array}$ & $\begin{array}{c}25 / 05 / 2016 \\
17: 10: 27\end{array}$ & $\begin{array}{l}\text { Claudinei Coppola } \\
\text { Junior }\end{array}$ & Aceito \\
\hline $\begin{array}{l}\text { Declaração de } \\
\text { Instituição e } \\
\text { Infraestrutura }\end{array}$ & $\begin{array}{l}\text { 5_ZIG_Declaracao_infraestrutura_HCF } \\
\text { MRP_USP.pdf }\end{array}$ & $\begin{array}{c}25 / 05 / 2016 \\
17: 09: 34\end{array}$ & $\begin{array}{l}\text { Claudinei Coppola } \\
\text { Junior }\end{array}$ & Aceito \\
\hline $\begin{array}{l}\text { Declaração de } \\
\text { Instituição e } \\
\text { Infraestrutura }\end{array}$ & $\begin{array}{l}\text { 5_ZIG_Declaracao_infraestrutura_HCF } \\
\text { MRP_USP.doc }\end{array}$ & $\begin{array}{c}25 / 05 / 2016 \\
17: 09: 19\end{array}$ & $\begin{array}{l}\text { Claudinei Coppola } \\
\text { Junior }\end{array}$ & Aceito \\
\hline $\begin{array}{l}\text { Declaração de } \\
\text { Pesquisadores }\end{array}$ & \begin{tabular}{|l|} 
4_ZIG_Declaracao_compromisso_tornar \\
publico resultados.pdf
\end{tabular} & $\begin{array}{c}25 / 05 / 2016 \\
17: 09: 10 \\
\end{array}$ & $\begin{array}{l}\text { Claudinei Coppola } \\
\text { Junior }\end{array}$ & Aceito \\
\hline $\begin{array}{l}\text { Declaração de } \\
\text { Pesquisadores }\end{array}$ & \begin{tabular}{|l|} 
4_ZIG_Declaracao_compromisso_tornar \\
publico resultados.docx
\end{tabular} & $\begin{array}{c}25 / 05 / 2016 \\
17: 09: 01 \\
\end{array}$ & $\begin{array}{l}\text { Claudinei Coppola } \\
\text { Junior }\end{array}$ & Aceito \\
\hline $\begin{array}{l}\text { Declaração de } \\
\text { Pesquisadores }\end{array}$ & \begin{tabular}{|l|} 
3_ZIG_Declaracao_compromisso_etica_- \\
pesquisa.pdf
\end{tabular} & $\begin{array}{c}25 / 05 / 2016 \\
17: 08: 40 \\
\end{array}$ & $\begin{array}{l}\text { Claudinei Coppola } \\
\text { Junior }\end{array}$ & Aceito \\
\hline $\begin{array}{l}\text { Declaração de } \\
\text { Pesquisadores }\end{array}$ & $\begin{array}{l}\text { 3_ZIG_Declaracao_compromisso_etica_ } \\
\text { pesquisa.docx }\end{array}$ & $\begin{array}{c}25 / 05 / 2016 \\
17: 08: 31 \\
\end{array}$ & $\begin{array}{l}\text { Claudinei Coppola } \\
\text { Junior }\end{array}$ & Aceito \\
\hline $\begin{array}{l}\text { Projeto Detalhado / } \\
\text { Brochura } \\
\text { Investigador }\end{array}$ & $\begin{array}{l}\text { 1_Protocolo_ZIG_versao1_0_25Mai16_f } \\
\text { inal.docx }\end{array}$ & $\begin{array}{c}25 / 05 / 2016 \\
17: 07: 58\end{array}$ & $\begin{array}{l}\text { Claudinei Coppola } \\
\text { Junior }\end{array}$ & Aceito \\
\hline Outros & 0_ZIG_Oficio_CEP.pdf & $\begin{array}{c}25 / 05 / 2016 \\
17: 07: 41 \\
\end{array}$ & $\begin{array}{l}\text { Claudinei Coppola } \\
\text { Junior }\end{array}$ & Aceito \\
\hline Outros & 0_ZIG_Oficio_CEP.docx & $\begin{array}{c}25 / 05 / 2016 \\
17: 07: 28 \\
\end{array}$ & $\begin{array}{l}\text { Claudinei Coppola } \\
\text { Junior }\end{array}$ & Aceito \\
\hline Folha de Rosto & 2_ZIG_Folha_de_rosto.pdf & $\begin{array}{c}25 / 05 / 2016 \\
17: 06: 19 \\
\end{array}$ & $\begin{array}{l}\text { Claudinei Coppola } \\
\text { Junior }\end{array}$ & Aceito \\
\hline
\end{tabular}

Situação do Parecer:

Aprovado

Necessita Apreciação da CONEP:

Não

Endereço: CAMPUS UNIVERSITÁRIO

Bairro: MONTE ALEGRE

UF: SP Município: RIBEIRAO PRETO

Telefone: (16)3602-2228 Fax: (16)3633-1144 E-mail: cep@hcrp.usp.br 


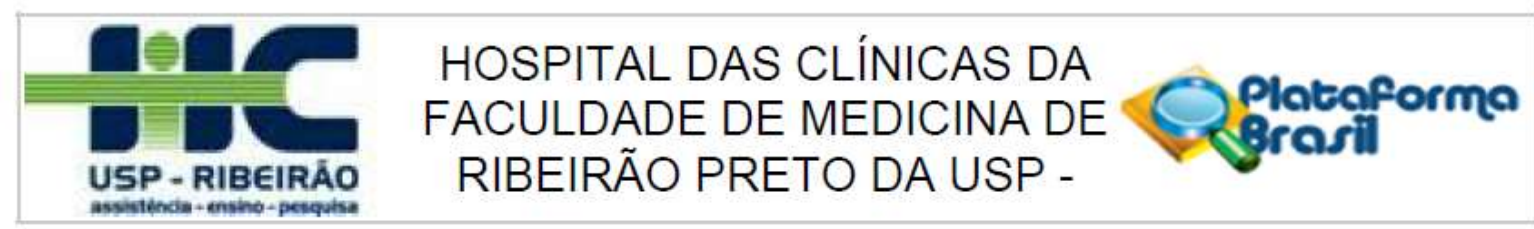

Continuação do Parecer: 1.604.787

RIBEIRAO PRETO, 24 de Junho de 2016

Assinado por:

MARCIA GUIMARÃES VILLANOVA

(Coordenador) 


\section{UNIVERSIDADE DE SÃO PAULO \\ FACULDADE DE MEDICINA DE RIBEIRĀO PRETO}

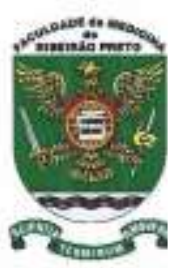

\section{Parecer: Defesa de Mestrado Profissional}

A médica Marili André Coelho-Valadão encontra-se sob minha orientação no Programa de Mestrado Profissional em Neurologia e Neurociências Clínicas. Cumpriu os créditos obrigatórios e completou as etapas do desenvolvimento da dissertação intitulada "Avaliação neurológica de recém- nascidos com microcefalia secundária à infecção congênita pelo virus zika". A aluna participou ativamente, sob minha orientação, do Ambulatório de Neurodesenvolvimento e Ambulatório de Crianças acometidas pelo Vírus Zika dessa instituição, através da avaliação neurológica dessas crianças. Considero que a aluna completou todas as atividades previstas para o curso de Mestrado Profissional e está apta para defesa pública de sua dissertação.

Atenciosamente,

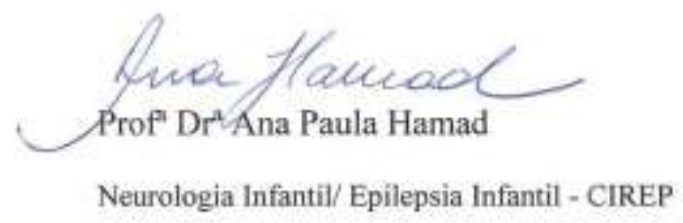

Ribeirão Preto, 13 de dezembro de 2018 